\title{
KONFLIK DAN INTEGRASI ISLAM POLITIK
}

\author{
Gunawan Undang \\ Prodi Ilmu Administrasi \\ Sekolah Pascasarjana Univ. Pembinaan Masyarakat Indonesia \\ gunawanundang@gmail.com \\ Husni Thamrin \\ Pascasarjana UIN Sultan Syarif Kasim Riau \\ husni.thamrin@uin-suska.ac.id
}

\begin{abstract}
Abstrak
The objective of this research is to examine conflict and integration; with using qualitative method and data collecting, interview, and mass media; data analysis technique with using qualitative descriptive as well as main study: conflict and integration does not increase consensus and performance, although it has potential to assist change.

The result of study show that main element which exacbrate internal conflict and decrease integration is in group solidarity and power struggle that triggered by power structure. It has ability to contribute conflict and decrease subjective solidarity with in group so that conflictual solidarity can hamper difference. Solidarity objective is main element to control conflict, improve integration, develop consensus, develop group work, and as requirement to develop interdependent with external group.

Non-litigation conflict resolution model through collective ijtihad can be developed how far kiai informal function as ummatan wasathon does not experience difference from cultural brokers into political brokers. If it is occur and flow polarization politic to fragmentation. This difference will experience gradually political leadership, paradigm contribution developed from Khaldun concept, Geertz, Horikoshi, and Turmudi.

Islamic Political Party generally can change from rationale political to textual political and from political concept, cultural Islamic Political Party which initiated by Islamic intellectual in New Order so that Islamic Political Party movement further tend to direct prophetic Islamic Political model.
\end{abstract}

Key words: conflict - integration - change 


\section{PENDAHULUAN}

Konflik internal partai politik Islam pasca- Orde Baru menunjukkan gejala yang kuat. Konflik antar-"anak kandung" NU, yakni PKB, PKU, dan PNU bahkan konflik internal PKB yang mengakibatkan kepengurusan "kembar" PKB versi Gus Dur/Muhaimin Iskandar dan PKB Alwi Shihab/Syaifullah Yusuf dalam Mukhtamar II PKB 2005, misalnya, menggambarkan fenomena rapuhnya ikatan solidaritas kelompok di kalangan Nahdliyin. Konflik internal PPP pun mengakibatkan fragmentasi ke dalam PBR bahkan PPPReformasi (tidak lolos verifikasi KPU). Hal yang sama dialamai Masyumi; sejak awal pembentukannya, partai generasi M. Narsir ini dilanda konflik internal sehingga mengaki- batkan fragmentasi ke dalam PBB, PMB, PII Masyumi, PUI, bahkan PAN. Demikian pula generasi Syarikat Islam terpecah ke dalam PSII dan PSII 1905. Selain itu, terjadi pula fragmentasi kepartaian dalam organisasi yang tidak "seinduk", seperti PK (PKS), PUMI, PID, PIB, PAY, dan KAMl. Munculnya ratusan partai politik sebagian besar menunjukkan perilaku yang sangat lapar kekuasaan, dirundung konflik internal yang berlarut-larut, kekuatan massa dijadikan andalan utama merebut kedudukan politik, membangun oligarki politik, dan bersifat feodalistis atau sentralistis. ${ }^{1}$ Parpol lebih banyak memperjuangkan fungsi kekuasaan daripada mempedulikan fungsi intermediasi dan pendidikan politik masyarakat; konflik-konflik internal partai bagi $56 \%$ responden dinilai telah memberi contoh yang buruk bagi pendidikan politik. ${ }^{2}$

Konflik dan fragmentasi kepar-taian menunjukkan gejala lemahnya solidaritas kelompok di antara partai Islam. Indikasi fenomena tersebut tergambar dari

\footnotetext{
1 J.Kristiadi, HU Kompas, Agustus 2005,hlm.7

2 Litbang, HU Kompas, 26 September 2005,hlm.5

178
}

intensifnya konflik kekuasaan dan gerakan ijtihad yang lebih mementingkan ijtihad politik kelompok daripada ijtihad kolektif. Setiap kelompok dan sub-kelompok melakukan iitihad politik masing-masing; ketidakpuasan anggota kelompok atau subkelompok terhadap kebijakan organisasi kelompoknya, direspons melalui ijtihad subkelompoknya masing- masing sehingga mengakibatkan terbentuknya partai baru. Meskipun pemben- tukan partai tersebut dijamin UU No. 2 Tahun 1999, tentang Partai Politik; yang kemudian diganti oleh UU No. 31 Tahun 2002, tentang Partai Politik; namun fragmentasi kepartaian tersebut selain menunjukkan lemahnya solidaritas kelompok, juga menggam-barkan disintergrasinya kinerja kelompok dan berpotensi meningkatkan konflik antarkelompok kepartaian. Gejala tersebut menggambarkan partai-partai Islam belum optimal dalam mengelola konflik dan meningkatkan integrasi. Konflik di negeri ini sering berubah menjadi disfungsional karena sering mengarah pada tindakan kaotif (kacau balau), destruktif, dan bahkan anarkis. ${ }^{3}$. Sikap emosional, kemarahan atau bahkan insiden pemukulan dan penusukan antar-anggota malah mewarnai Mukhtamar Islah PBR. ${ }^{4}$ Kader PBR dikeroyok tiga orang hingga menderita luka tusuk dalam Mukhtamar Islah PBR di Bali. ${ }^{5}$

Selain partai politik, peranan informal kiai berpotensi sebagai mediator konflik, mengingat kiai memiliki posisi strategis dan sentral dalam masyarakat serta memainkan peran perantara budaya (cultural brokers) bagi umat Islam dan memiliki otoritas yang sangat besar dan kharismatik (Geert, 1982 dan Horikoshi, 1987), dan kiai adalah elit politik yang mempunyai pengaruh kuat terhadap sikap politik umat Islam (Turmudi, 2004). Namun, ada gejala bahwa posisi strategis

\footnotetext{
${ }^{3}$ Saeful Millah, HU Pikiran Rakyat, 5 Juli 2005, hIm.20

${ }^{4}$ HU Kompas, 24 April 2006, hlm.2

5 HU Republika, 24 April 2006, hlm.3
} 
Gunawan Undang, Husni Thamrin; Konflik dan Integrasi Islam Politik

kiai tersebut belum sepenuhnya berfungsi sebagai mediator konflik partai-partai Islam, karena diduga sebagian besar kiai yang semula berkedudukan sebagai "perantara budaya" dan netral politik, pada pascaOrde Baru posisinya sudah mengalami pergeseran karena keterlibatannya ke dalam kekuasaan. Turmudi (2004) mengemukakan bahwa konflik yang muncul karena perbedaan pandangan politik kiai dapat melahirkan konflik tidak langsung di antara pengikutnya. Pada pasca-Orde Baru, fenomena tersebut di antaranya tercermin dalam dukungan 22 Kiai Langitan NU terhadap PKB versi Alwi Shihab- Syaifullah Yusuf (hasil MLB Yogyakarta) mengajukan kasasi ke Mahkamah Agung (MA) atas putusan Pengadilan Negeri Jakarta Selatan yang memenangkan PKB versi Gus DurMuhaimin Iskandar. ${ }^{6}$ Forum Kiai Langitan akan tetap menolak bergabung atau ishlah dengan DPP PKB di bawah kepemimpinan Gus Dur-Muhaimin Iskandar, jika putusan kasasi tetap menolak gugatan Alwi Shihab.7 Meskipun putusan kasasi MA pada akhirnya memenangkan PKB Alwi Shihab, secara sosiologis penyelesaian konflik melalui pendekatan litigasi tersebut menunjukkan fenomena disfungsinya peranan informal kiai sebagai ummatan wasathon (penengah/"wasit") dalam masyarakat.

Sulitnya partai politik Islam melakukan resolusi konflik dan disfungsinya peranan informal kiai sebagai mediator penyelesaian konflik partai-partai Islam diduga karena orientasi kepentingan politik dan kekuasaan kelompok lebih kuat dari pada membangun solidaritas antar-kelompok. Fenomena tersebut menunjukkan bahwa semangat keagamaan (nilai-nilai ideologi keislaman)

6 HU Republika, 22 Agustus 2005, hlm.8, HU Kompas, 22 Agustus 2005, hlm.4

7 K. H. Idris Marzuki, pengasuh Pondok

Pesantren Lirboyo, Kediri, dalam $\mathrm{HU}$

Republika, 22 Agustus 2005, hlm. 12 belum sepenuhnya dijadikan landasan dan perekat perjuangan kelompok dalam berpolitik. Hal ini akan memperlemah terhadap kinerja kelompok dan menghambat proses pencapaian konsensus untuk memperbaiki lembaga kepartaian Islam.

Berkaitan dengan fenomena tersebut, secara konseptual Khaldun (2000) mengemukakan bahwa jika tidak ada solidaritas sosial (ashobiyah) dalam suatu kelompok sosial, maka konflik tidak bisa dihindari; semangat agama dapat meredakan konflik dan meningkatkan integrasi, tetapi hal tersebut tidak dapat berhasil tanpa kekuatan solidaritas. Selain itu; menurut Khaldun, politik yang baik menghendaki kekuasaan yang tidak terfragmentasi dan terpusat pada figur yang berwibawa dankuat.

\section{Fenomena Islam Politik di Indonesia}

Hasil penelitian yang pernah dilakukan oleh peneliti lainnya yang terkait dengan konflik dan integrasi Islam politik di Indonesia antara lain sebagai berikut yakni:

Pertama, hasil penelitian Husnul Aqib Suminto (1985). Suminto meneliti kebijakan Belanda terhadap Islam di Indonesia pada abad ke-19 dan ke-20. Laporan disertasi dalam rangka mengikuti program Post Graduate Course of Islamic Studies in the Netherlands dari IAIN Syarif Hidayatullah, Jakarta tersebut kemudian diterbitkan oleh LP3ES, dengan judul Politik Islam Hindia Belanda, (cetakan ke-3, 1996). Menurut Suminto:"Keinginan keras untuk tetap berkuasa di Indonesia, mengharuskan pemerintah Hindia Belanda untuk menemukan politik Islam yang tepat, karena sebagian besar penduduk kawasan ini beragama Islam. Dalam perang menaklukkan bangsa Indonesia selama sekian lama, Belanda menemukan perlawanan keras justru dari pihak raja-raja Islam terutama, sehingga tidaklah mengherankan bila kemudian Islam dipandangnya sebagai ancaman yang harus dikekang dan ditempatkan di bawah 
pengawasan yang ketat.

Kedatangan Snouck Hurgronje pada

akhir abad ke-19 berhasil memberikan alternatif jalan ke luar. Analisa tentang Islam mendorongnya untuk bersikap netral terhadap ibadah agama, di samping bertindak tegas terhadap setiap kemungkinan perlawanan orang-orang

analisa pemisahan antara agama dan politik tersebut, nampaknya hanya sesuai dengan kondisi peralihan abad ke-20, sebab perkembangan selanjut-nya ternyata menyimpang dari garis politik Snouck Hurgronje. Ketentraman yang dicapai pun tidak bisa bertahan lama, justru setelah umat Islam di kawasan ini mulai kebangkitannya. Dorongan kebangkitan Islam dari luar negeri berpadu dengan perubahan sosial akibat lajunya modernisasi di bawah pemerintahan kolonial. Proses modernisasi umat Islam ini berhasil mempersegar penghayatan agamanya, sehingga mampu memahami Islam sebagai agama yang sempurna dan sebagai pandangan hidup yang lengkap.

Sebagian wawasan dan saran Snouck Hurgronje sesudah dua dasawarsa pertama abad ke-20 tidak lagi sesuai dengan situasi kondisi, karena umat Islam - dalam membela agamanya - ternyata tidak mengabaikan kegiatan politik. ... Demikian juga pelarangannya terhadap ajarantarekat; seperti peristiwa Haji Hasan di Garut, Cianjur, Sukabumi, dan Cilegon, didasari oleh rasa kekhawatirannya yang berlebihan untuk kepentingan politik penjajah Belanda..." (Suminto, 1996:199-200).

Laporan penelitian Suminto secara substansial melengkapi hasil studi Steenbrink (1984); yang sama-sama meneliti Islam di era kolonial Belanda.

Kedua, hasil penelitian Deliar Noer (1973). Studi ini membahas tentang gerakan Islam pada masa pemerintahan Belanda dengan judul The Modernist Muslim Movement in Indonesia 1900 1942 diterbitkan Oxford University Press. Disertasi program doktor pada Universitas
Islam fanatik. Politik kembar antara toleransi dan kewaspadaan ini dimaksudkan untuk membangun fondasi bagi ketenteraman kehidupan beragama dan meletakkan modus vivendi antara pemerintah kolonial dengan umat Islam. Namun politik Islam Snouck Hurgronje yang didasarkan atas Cornel di thaca, New York, Amerika Serikat ini kemudian diterjemahkan oleh peneli-tinya sendiri ke dalam Gerakan Modem Islam di Indonesia 1900-1942 (cetakan ke-8, 1996) diterbitkan LP3ES. Secara umum, gerakan pembaharuan Islam di Indonesia pada kurun waktu 1900-1942 tidak terlepas dari pengaruh Timur Tengah, seperti Muhammad Abduh dan Rasyid Ridha yang menitikberatkan terhadap penegakan iithihad, menolak taqlid, dan melihat kepada Rasul serta para sahabat sebagai contoh dalam mengerjakan ibadah. Selain itu, pemikiran Ibn Taymiyah dan Ibn al-Qayyim pun mempengaruhi kalangan modernis Islam Indonesia. Tentang perkembangan dan sifat gerakan modem Islam di Indonesia, Noer mengemukakan:

"Dalam pembicaraan kita tentang berbagai organisasi, baik sosial, pendidikan ataupun politik, telah kita lihat berbagai sifat tiap organisasi itu, kecenderungan yang mereka tekankan dalam pemikiran masingmasing. Sifat dan kecenderungan ini dibentuk oleh pimpinan organisasi serta lingkungan tempat organisasi itu bergerak. Seakan terdapat bukan satu pergerakan di Indonesia, melainkan beberapa, masingmasing dengan sifatnya sendiri-sendiri. Adanya partai yang bernon-koperasi (umpamanya Syarekat Islam setelah tahun 1921 dan Persatuan Muslimin Indonesia) dan partai berkoperasi (umpamanya Partai Islam Indonesia), adanya partai yang progolongan kebangsaan (Persatuan Muslimin Indonesia), dan organisasi yang tampaknya anti-golongan kebangsaan (umpamanya Persatuan Islam), serta adanya organisasi yang bersifat toleran (Muhammadiyah) di samping yang keras 
Gunawan Undang, Husni Thamrin; Konflik dan Integrasi Islam Politik

(Persatuan Islam), semuanya memperlihatkan berbagai gerakan "(Noer, 1996: $319-20$ ).

Selanjutnya Noer mengemu-kakan bahwa dampak dari golongan modern yang berkesempatan mengikuti pendidikan menghasilkan kepemim-pinan modern dalam gerakan pembaruan Islam dari berbagai profesi, seperti kalangan ulama (Haji Rasul,Kyai Haji Ahmad Dahlan); kalangan perniagaan (Haji Abdullah Ahmad, Samanhoeddhi, Ahmad Hassan); kalangan bangsawan, priyayi atau adat (Tjokoaminoto, Salim, Moeis, Hasan Djajadiningrat, Mohammad Natsir); dan kalangan pamong praja (Gunawan, Djajadiningrat, Moeis, Mohammad Natsir). Secara geografis, pemimpin tersebut kebanyakan berasal dari Jawa dan Minangkabau (Noer, 1996:327-330).

Noer menggambarkan ketidak konsistenan dan politik diskriminatif Belanda terhadap Islam dan non-Islam sebagai berikut:

"Sikap Belanda terhadap Islam di Indonesia tidak tetap. Di satu pihak Islam dilihat sebagai agama, dan katanya pemerintah netral terhadap ini. Tetapi sebaliknya, pemerintah Belanda pun mengambil sikap diskriminatif dengan memberi kelonggaran kepada kalangan missionaris Kristen lebih banyak, termasuk bantuan uang. Pemerintah juga melarang banyak kegiatan missionaris Islam di daerah animisme, sedangkan missionaris Kristen leluasa masuk. Para pejabat pemerintah Belanda membiarkan saja segala macam penghinaan yang dilontarkan terhadap Islam kecuali satu kejadian, dan ini pun ketika Jepang bersiap melancarkan invasi ke Indonesia. Sebaliknya, tulisan kalangan Islam yang dirasakan menyinggung perasaan orang Belanda atau orang Kristen cepat dibungkem. Orang Islam melihat kebijaksanaan Belanda di
Indonesia sebagai upaya untuk memperlemah kedudukan Islam di negeri ini.

Organisasi modern Islam; terutama Muhammadiyah dan Syarikat Islam, dapat dilihat sebagai benteng terhadap kebijakan ini. Mereka mempergunakan cara-cara Belanda dan cara-cara pihak Kristen dalam membangun organisasi, dalam memperbaiki pendidikan dan dalam mencari pengikut. Dalam politik sebenarnya pihak Islam memulai gerakannya dengan banyak sedikitnya menaruh kepercayaan terhadap kebijaksanaan Belanda yang melancar- kan Politik Etis, tetapi lambat laun (dan ini segera saja sebenarnya) keperca- yaan ini hilang setelah kekecewaan banyak sekali. ... (Noer, 1996: 333-334).

Noer pun mengemukakan tentang perubahan sosial tentang harmonisasi pola hubungan di antara kalangan modern dan tradisionalis yang di antaranya ditandai dengan berdirinya Nahdlatul Ulama (1926) dan Persatuan Tarbiyah Islamiyah (1929). Sekitar 1935 mereka menyerukan perlunya kesadaran toleransi dan mulai bangkit- nya pengakuan bersama terhadap Islam sebagai satu kesatuan antara agama dan politik. Kedua golongan modernis dan tradisionalis tersebut bersatu padu mendirikan Majlis Islam A'laa Indonesia (1938).

Gejala hubungan kurang harmonis antara kalangan modern Islam dengan kalangan kebangsaan yang netral agama mulai tumbuh sejak berdirinya Partai Nasional Indonesia (1927) yang mengambil sikap netral terhadap agama. Seorang tokoh partai tersebut; Soekarno, misalnya, melaku- kan justifikasi atas tindakan Mustaffa 
Kemal Attaturk dari Turki (dan rekomendasi Cristian Snouck Hurgronje terhadap pemerintah Hindian Belanda) yang membenarkan pemisahan agama dari negara. Situasi tersebut menim- bulkan konflik di antara kalangan modernis Islam; seperti Mohammad Natsir dengan Presiden Soekarno.

Ketiga, hasil penelitian Harry J. Benda (1958). Harry J. Benda melakukan penelitian pada masa penjajahan Jepang. Disertasi doktornya pada Graduate Faculty of Cornell University, berjudul The Crescent and the Rising Sun: Indonesian Islam under the Japanese Occupation, 1942-1945 (1958), pada N. V. Uitgeverij W. van Hoeve, Den Hag, telah diterjemahkan ke dalam Bulan Sabit dan Matahari Terbit: Islam Indonesia pada Masa Pendudukan Jepang (1980), yang diterbitkan Pustaka Jaya. Kesimpulan umum laporan penelitian tersebut sebagai berikut:

"Meskipun waktunya sangat singkat (Maret 1942-Agustus 1945) masa penguasaan Jepang adalah masa traumatik yang secara mendalam mempengaruhi banyak aspek kehidupan Indonesia. Status politik yang pada mulanya dibayangkan Jepang (akan lebih menguntungkan) bagi Indonesia (tetapi) bahkan lebih kolonial daripada di bawah pemerintahan Belanda. ... politik Jepang terhadap para pemimpin Islam, yang merupakan perbedaan utama ketiga dari praktek Belanda, tidak kalah penting pengaruhnya bagi kehidupan politik Indonesia di masa depan. Pada mulanya, sebagaimana pendahulunya, Jepang juga tidak ingin, dan barangkali lebih enggan, untuk memberi kebebasan yang murni bagi kehidupan politik Islam. ... Sejarah Indonesia mutakhir telah mencerminkan secara luas buah-buah penting yang telah tercapai Islam Indonesia di masa modern, akan tetapi dia juga menunjukkan bahwa para pemimpin Islam; yang terpecah belah di kalangan sendiri, bukanlah tanpa persaingan- persaingan yang sungguh-sungguh di dalam perjuangan untuk merebut kesetiaan politik rakyat Indonesia" (Benda, 1980: 237-244).

\section{Hubungan Islam dan Partai Politik}

Paradigma hubungan antara
Islam dan modernisasi serta hubungan antara Islam dan negara atau siyasah syariyah menentukan terhadap hubungan antara Islam dan politik, termasuk sistem kepartaian. Di-qiyas-kan dari pandangan Syamsuddin (1993) tentang hubungan antara Islam dan negara, hubungan antara Islam dan partai politik pun dapat dikategori-sasikan menjadi tiga, yakni pertama, partai Islam yang mengintegrasikan antara Islam dan politik. Kelompok partai ini secara formal mencantumkan Islam sebagai asasnya. Liddle (1993) mengistilahkan kelompok ini sebagai kelompok skriptual-literal yang mengedepankan idealistik, formalistik, dan tekstual- tradisonalis. Praja (2006) mengelom- pokkan corak pemikiran kalangan ini sebagai Islam konservatif atau tradisionalis yang sering dikaitkan dengan cita-cita pembentukan negara Islam atau Dar Islam, yakni Daulah Islamiyah berdasarkan Khilafah sebagaimana pernah dialami pada masa keemasan Kerajaan Usmani. Dalam merespons modernisasi, pemiki- ran kelompok ini cenderung tidak kontekstual dengan realitas yang ada, karena bentukbentuk negara di bekas negaranegara Islam sudah berubah berdasarkan orientasi negaranya masing-masing dan secara nyata sudah tidak ada lagi negara Islam 
yang berdasarkan Khilafah pascakeruntuhan Kerajaan Turki Usmani (1300-1922 M.) pada tahun 1922. Beberapa kelompok yang secara konsisten memperjuangkan Khilafah tersebut di antaranya adalah Hizbut Tahrir, termasuk Hizbut Tahrir Indonesia (HTI) dan Jamaah AlTablighi.

Kedua, kelompok partai Islam yang menyimbiosiskan antara idealitas keislaman dengan realitas yang ada, yakni partai yang tidak secara formal mencantumkan Islam sebagai asasnya. Kelompok partai ini lebih rasionalistik,realistik,substantivistik,dan kontekstual-modernis. Kelompok ini menitikberatkan pada "isi" daripada "bentuk". Seperti halnya dalam memandang hubungan antara Islam dan negara, dalam memandang hubungan antara Islam dan partai politik pun kelompok kepartaian ini lebih menitikberatkan pada kemaslahatan bagi tegaknya nilai-nilai ajaran Islam, sehingga konsep perjuangannya sering dikaitkan dengan Darus Salam atau negara kesejahteraan. Kelompok rasionalistik ini memandang bahwa jika seorang Muslim dapat menegakkan ajaran agama dalam partai politik tertentu seperti dalam partai yang berasas kebangsaan, demokrasi, dll. bahkan dalam partai politik non-Islam (kafir) sekalipun -- maka partai tersebut dapat dipandang sebagai "partai Islam" dan aktif di dalamnya lebih afdhal daripada keluar darinya. Karena dengan demikian dapat diharapkan akan ada orang lain bersimpati yang kemudian dapat memperjuangkan dan menegakkan ajaran keislaman melalui partai politik. Hal tersebut di-qiyas-kan dari pemikiran al-Mawardi (dalam Hosen, 1993) yang menegaskan bahwa "jika seorang Muslim dapat menegakkan ajaran agama di suatu wilayah negara kafir, maka wilayah itu dipandang sebagai Dar al-Islam dan bertempat tinggal di sana lebih afdhal ketimbang berhijrah darinya, sebab dengan demikian dapat diharapkan akan ada orang lain bersimpati yang kemudian masuk agama Islam.

Gerakan pembaruan pemikiran Islam politik substantif Cak Nur (Nurcholish Madjid) dengan jargonnya "Islam, Yes, Partai Islam, No" seperti yang dikembangkan dan dijabarkan Mulkhan (1989) dan Effendy (1998), termasuk ke dalam kelompok kedua ini. Kelompok ini lebih mementingkan substansi, membawa kemaslahatan, dan adanya jaminan bagi tegaknya ajaran Islam. Oleh Praja (2006), corak pemikiran kalangan ini dikelompokkan ke dalam Islam modernis dan reformis. Chaidar (1999) mengklasifikasikan partai politik Islam sebagai partai yang memakai asas Islam maupun bukan Islam (ghairul Islam), namun memberikan kebaikan bagi tegaknya ajaran keislaman.

Sedangkan kelompok ketiga adalah partai sekuler yang menolak paradigma kelompok pertama dan kedua. Kelompok ini sering dikaitkan dengan prinsip-prinsip memisahkan antara agama dan negara atau agama dan politik. Meskipun demikian, sekularisasi Barat-sekuler, berbeda, misalnya, dengan "sekularisasi" Turki- "sekuler". Dalam Barat-sekuler negara tidak mengontrol agama atau sebaliknya, sedangkan dalam Turki- "sekuler"; dalam batas-batas tertentu, negara dapat "mengontrol" agama (Islam), karena secara kultural identitas bangsa Turki identik dengan keislamannya, meskipun ketatanegaraannya bentuk republik dengan asas nasionalis.Bertitik tolak 
AL-Fikra: Jurnal Ilmiah Keislaman, Vol. 15, No. 2, Juli-Desember 2016

dari paradigma tersebut; dalam konteks keindonesiaan, Gambar berikut memvisualisasikan hubungan antara Islam dan modernisasi, Islam dan negara, dan Islam dan politik dimana kedudukan partai politik Islam "bersimbiotik" dengan bentuk kenegaraan Republik Indonesia yang berasaskan Pancasila. 
Gunawan Undang, Husni Thamrin; Konflik dan Integrasi Islam Politik

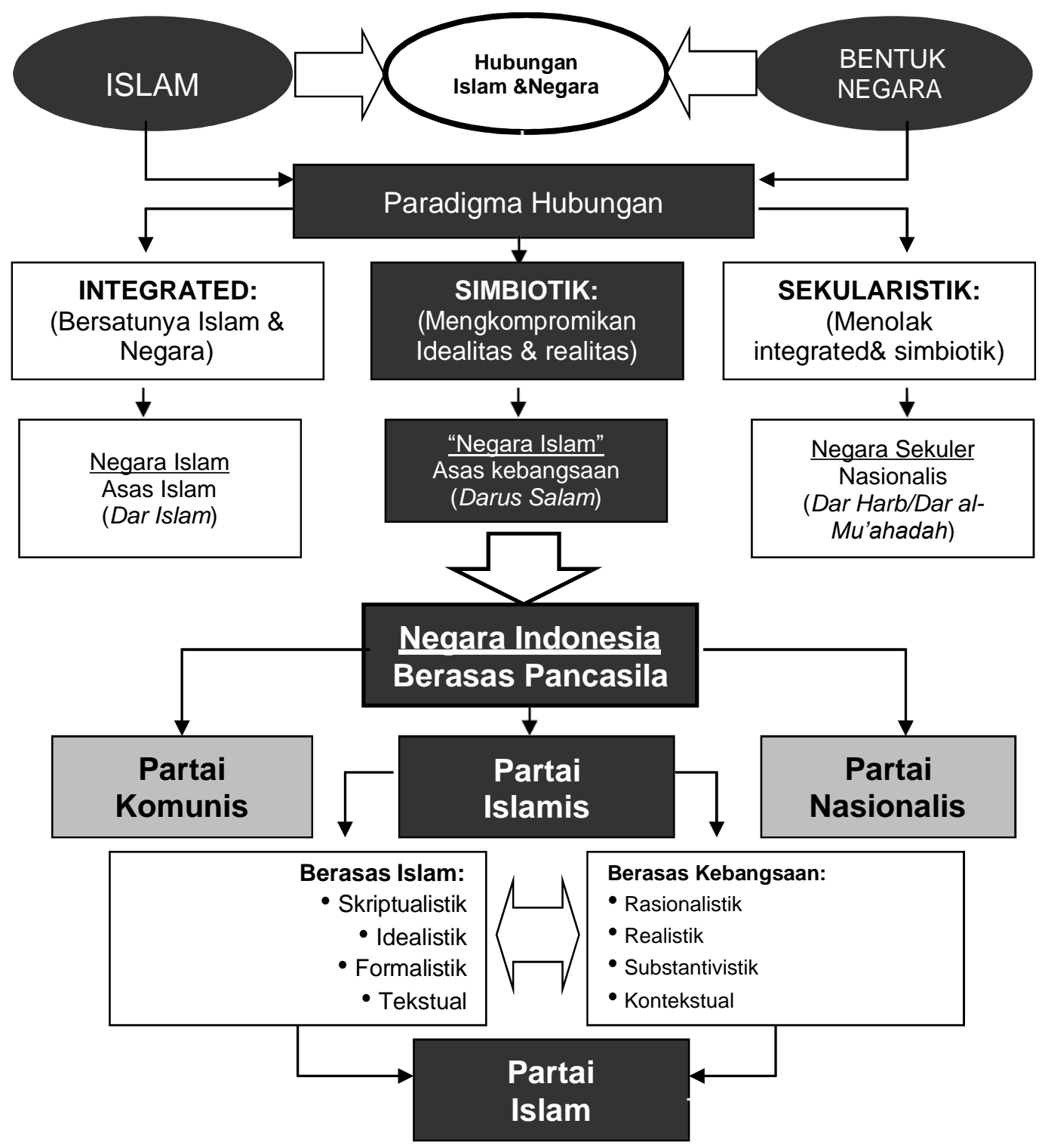

Gambar 1

Hubungan Islam-Negara, dan Islam-Politik 
Bertitik tolak dari hubungan antara Islam dan modernisasi, figh siyasah, hubungan Islam dan negara, dan hubungan Islam dan politik di atas, relatif rasional apabila Chaidar (1999: vi) mendefinisikan bahwa partai Islam adalah partai yang tidak selalu berasaskan Islam, selama memberikan maslahat bagi Islam, seperti didefinisi-kan berikut:

"Partai yang dipimpin oleh tokoh Islam, memakai asas Islam maupun bukan Islam (ghairul Islam) sebagai fundamen partai dan orientasi partai yang terbuka dan tertutup, yang menerima anggota dari berbagai kalangan dan yang hanya menerima anggota dan golongan Islam saja dan berusaha meraih simpati untuk merebut suara dari kalangan Islam sebagai basis utama dukungan, maka itulah partailslam".

Bertitik tolak dari definisi tersebut, indikator pokok definisi istilah partai politik Islam dalam penelitian ini adalah (1) tokoh pendiri, (2) induk organisasi pendiri, (3) berbasis massa induk orga-nisasi, (4) menggunakan asas Islam maupun bukan (ghairul Islam), dan (5) memberikan maslahat bagi tegaknya ajaran keislaman. Dalam penelitian ini, partai politik Islam diinterpretasikan sebagai institusi partai politik yang didirikan oleh tokoh (elit politik) Islam, memiliki induk organisasi Islam, berbasis massa Islam berdasarkan induk organisasi pendiri, berasaskan Islam maupun Pancasila dan UUD 1945, serta memberikan maslahat bagi tegaknya ajaran keislaman. Partai Islam dimaksud adalah PBB, PPP, PPNUI, PKS, PBR, PKB, dan PAN. Penetapan indikator tersebut pun mengacu pada pendapat Liddle (1993) tentang pengelompokkan dan orientasi partai politik Islam yang tidak hanya menekankan terhadap formalisme asas sebagai dasar perjuangan partai, yakni kelom-pok substansialkontekstual (modernis) yang lebih berorientasi pada "isi" daripada "bentuk", selain kelompok skriptual-literal (tradisionalis) yang lebih mengedepankan "simbol" daripada "isi".

\section{Gerakan Pembaruan Pemikiran Politik Islam di Indonesia}

Menurut Harun Nasution (1975: 11-

12) modernisme (bukan modemi-sasi, pen.) dalam masyarakat Barat mengandung arti pikiran, aliran, gerakan, dan usaha untuk mengubah faham-faham, adat istiadat, institusi-institusi lama, dan sebagainya untuk disesuaikan dengan suasana baru yang ditimbulkan oleh kemajuan ilmu pengetahuan dan teknologi modern. Modernisme dalam kehidupan agama di Barat mempunyai tujuan untuk menyesuaikan ajaran-ajaran yang terdapat dalam agama Katholik dan Protestan dengan ilmu pengetahuan dan falsafah modern. Aliran ini akhirnya menimbulkan sekularisme di masyara-kat Barat.

Permulaan abad modern Islam;sebagai pengaruh modernisme Barat, masuk ke dunia Islam pada awal abad ke-19 melahirkan ideide baru, seperti rasionalisme, nasionalisme, demokrasi, dan sebagainya sehingga dalam hal tertentu menimbulkan persoalan baru dan merangsang kebangkitan pemikir-pemikir Islam untuk melepaskan umat dari kemunduran menjadi kemajuan, terutama setelah kalangan orientalis mengadakan studi tentang keislaman, seperti yang dilakukan $\mathrm{C}$.

C. Adams (1933), W. C. Smith (1943), dan H. A. R. Gibb (1946).

Karena dalam hal-hal tertentu kata "modemisme" dapat diinterpre-tasikan negatif (seperti dianggap identik dengan Westernisasi, Westermisme); di samping arti positif, maka oleh para pemikir kontemporer; termasuk misal-nya oleh Harun Nasution dan Nurcholish Madjid, terminologi tersebut diterjemahkan ke dalam kata "pembaha-ruan" (pembaruan). Dalam arti pembaruan tradisi pemikiran berlandas-kan hukum dan etika Islam. 
Gunawan Undang, Husni Thamrin; Konflik dan Integrasi Islam Politik

Menurut Nurcholish Madjid modernisasi ialah rasionalisasi; bukan Westermisasi, yang ditopang oleh dimensi-dimensi moral dengan berpijak pada prinsip-prinsip iman kepada Tuhan Yang Maha Esa (Madjid, 1968; dalam Madjid, 1998: 17--18).

Menurut Harun Nasution (1986: 110 -

11) sebelum timbulnya ide pembaruan, gerakan pemurnian Wahabiyah di Minangkabau terlebih dulu masuk ke Indonesia yang dibawa oleh para haji yang pulang dari Mekah, di antaranya Haji Miskin. Gerakan ini bertujuan menentang adat yang bertentangan dengan syar'at Islam. Kaum adat meminta bantuan pada Belanda sehingga pecahlah Perang Padri.

Ide pembaruan masuk ke Indonesia pada permulaan abad ke-20 melalui Majalah Al-Imam yang terbit di Malaysia oleh Said Muhammad Agil, Syeh Muhammad Al-Kalali, dan Syeh Taher Jalaluddin. Al-Imam mengan-dung ide-ide pembaruan Majalah A/Manar kepunyaan Rasyid Ridha. Pengaruh majalah tersebut terlihat dalam Majalah AlMunir, terbit di Padang tahun 1911, di bawah asuhan Abdullah Ahmad, Abdul Karim Amarullah, dan Muhammad Taib.

Menurut Nasution, tahun 1901 di Jakarta berdiri Jamiat Khair yang melakukan pembaruan di bidang pendidikan yang memasukkan ke dalam kurikulumnya bahasa danilmu pengetahuan Barat. Siswanya kemudian meneruskan studi ke Istambul. Atas undangan Jamiat Khair, datang seorang ulama Sudan pengikut Muhammad Abduh ke Indonesia; Syeh Ahmad Surkati. Kemudian ia membentuk Al-Islah wal Irsyad yang melakukan pembaruan di bidang pendidikan dan pemikiran melalui Majalah Al-Zakhirah.

Pembaruan yang lebih luas pengaruhnya di Indonesia dilakukan K. H. Ahmad Dahlan yang mendirikan Muhammadiyah tahun 1912. Organisasi yang banyak dipengaruhi pemikiran-pemikiran
Rasyid Ridha ini melakukan pembaruan melalui lembaga-lembaga pendidikan yang didirikannya.

Selain itu, sejarah pembaruan di Indonesia pun tidak terlepas dari perananperanan Haji Agus Salim, Said Umar Tjokroaminoto (Sarekat Islam), Hasan Bandung (Persis), Nahdatul Ulama, Jamiatul Washliah, dll.

Gerakan pembaruan berikutnya di bidang tradisi pemikiran Islam di Indonesia mulai menampakkan intensitasnya pada tahun 1970-an. Ide gerakan pembaruan periode ini dipengaruhi pembaruan pemikiran Islam abad pertengahan dan kontemporer, di mana nama Nurcholish Madjid sering disebut sebagai tokoh utamanya, selain Ahmad Wahib, Djohan Effendy, Dawam Rahardjo, Jalaluddin Rakhmat, dan Abdurrahman Wahid.

Generasi pembaru ini oleh R. William Liddle (1993: 53) disebutnya sebagai kaum substansialis (modernis) yang dimotori Nurcholish Madjid. Oleh Masdar F. Mas'udi (1993: 28) dan Mohamad Sobari (1993: 26) kaum ini disebutnya sebagai neo-modernis. Dalam pembaruan pemikiran; menurut Liddle, kaum substansialis ini mempunyai "rival" yang sangat kontras, yakni kaum skriptualis (tradisionalis). Secara kelembagaan, "representasi" kaum skriptualis ini adalah Dewan Dakwah Islamiyah Indonesia (DDII) dan Media Dakwah.

Dalam terminologi lain; untuk kepentingan alat analisis dan untuk "membedakan" kedua kaum ini, dapat dipasangkan ke dalam dua pasangan kata: substansialis-skriptualis, modernis tradisionalis, dan kontekstual-tekstual.

Kaum substansialis melakukanberbagai pembaruan pemikiran Islam, seperti di bidang pluralitas dan toleransi keagamaan, ekonomi, politik, dan pendidikan. Menurut Liddle, kaum substansialis selama Orde Baru banyak 
muncul ke permukaan, mendapatkan liputan media yang jauh lebih luas, karena punya aspirasi politik yang dekat dengan pemerintah, dan bahkan banyak mendapatkan keuntungan dan bergantung pada politisipolitisi otoritarian Indonesia. Hal ini sudah barang tentu berbeda dengan kaum skriptualis-tradisionalis yang tidak memiliki akses ke pusat kekuasaan Soeharto yang menutup aspirasi politik mereka dalam memperjuangkan syar'at Islam bahkan Negara Islam yang dianggap bersebrangan dengan ideologi Pancasila.

Kalangan substansialis melaku-kan pembaruan pemikiran bermula dari pidato Nurcholish Madjid di tahun 1970 (3 Januari 1970, di Jakarta, -pen.) tentang "Keharusan Pembaharuan Pemikiran Islam dan Masalah Integrasi Umat' (Liddle, 1993: 55).

Upaya pembaruan dalam konteks modernitas, Nurcholish Madjid meman-dang bahwa modemisasi adalah suatu keharusan, malah kewajiban yang mutlak. Modernisasi berarti rasionalisasi untuk memperoleh daya guna dalam berpikir dan bekerja yang maksimal, guna kebahagiaan umat manusia adalah perintah Tuhan yang imperatif dan mendasar. Modernisasi berarti berpikir dan bekerja menurut fitrah atau Sunnatullah (Hukum Illahi) yang haq (sebab, alam adalah haq). IImu pengetahuan diperoleh manusia melalui akalnya (rasionya), sehingga modern berati ilmiah, berati pula rasional. Sekalipun kemodernan bersifat mutlak, namun kemodernan (modernity) sifatnya relatif, karena terikat oleh ruang dan waktu. Sesuatu yang sekarang dianggap modern, di masa yang akan datang dapat dipastikan bersifat kolot. Sedangkan yang modern secara mutlak ialah yang benar secara mutlak, yakni Tuhan Yang Maha Esa (Madjid, 1998: 172-174). Hakikat sejarah pemikiran dalam Islam ialah kelangsungan dialog integral, yaitu dialog berdasarkan iman, namun tidak lepas dari konteks sejarah (Madjid, 1998: 315).

Menurut Mohamad Sobary, pemikiranpemikiran pembaruan bersifat responsif terhadap tuntutan zaman. Mereka "menyimpan" gagasan-gagasan generasi pendahulu dan menelorkan gagasan baru yang sesuai dengan tuntutan dan kondisi sosio-politik dan kultural dalam masyarakat kita. Konsep pribumisasi Islam dan Islam kontekstual; misalnya, merupakan contoh model gagasan kalangan pembaruan (Sobary, 1993: 26).

Gagasan pembaruan Madjid dalam pidatonya tentang "Keharusan Pembaharuan Pemikiran Islam dan Masalah Integrasi Umat" tanggal 3 Januari 1970 di Jakarta dalam malam silaturahmi organisasi pemuda, pelajar, mahasiswa, dan sarjana Muslim yang tergabung dalam HMI, GPI, PII, dan Persami, terutama penggunaan terminologi "sekulerisasi" yang dianggap sebagai salah satu bentuk "liberalisasi", sempat memicu polemik di kalangan intelektual Islam -khususnya dari kalangan yang disebut Masdar F. Masdudi (1993: 28) sebagai kaum neorevivalis yang nenekankan Islam formalpartikular atau yang disebut $R$. William Liddle (1993: 53 - 55) sebagai kaum skriptual-literal -sehingga Madjid sempat dituduh "modemis sekuler". Meskipun dalam berbagai kesempatan Madjid berupaya menjelaskan apa yang dimaksud dengan "sekulerisasi" tersebut tidak sama dengan "sekulerisme" (ideologi), namun tuduhan sebagai "sekularis" terhadap dirinya terus berlanjut, bahkan hingga sekarang, dengan alasan sekularisasi tanpa sekulerisme adalah mustahil. Bantahan Madjid tentang "sekularisasi" tidak berati "sekulerisme" dituangkan di dalam Madjid (1998: 221-233, dan 257-260). Intinya; menurut Madjid, karena pengertian "sekular", "sekularisasi", dan "sekulerisme" dalam konteks terminologi yang digunakannya, maka 
ia berketetapan istilah-istilah tersebut lebih baik menggunakan istilah teknis lain yang lebih tepat dannetral.

Agaknya; menurut hemat penulis, kesimpangsiuran tersebut bersumber dari ketidaktepatan penggunaan terminilogi "sekularisasi". Gagasan "sekulerisasi" Madjid; sejak awal bergulirnya di tahun 1968-an seperti di dalam makalah "Modernisasi ialah Rasionalisasi, bukan Westemisasi" (1968), secara substansial tidak berubah dengan apa yang digulirkannya kembali tahun 1970-an, bahkan hingga tahun 1992-an sebagaimana tertuang di dalam makalahnya "Penyegaran Paham Keagamaan di Kalangann Generasi Muda Mendatang" yang disampaikan di Taman Ismail Mazuki, Jakarta, 21 Oktober 1992. "Sekulerisasi" tidak identik dengan "sekulerisme" sebagaimama faham "Westernisme" yang "menegasikan" al-Haqq (Maha Benar). "Sekularisasi" Madjid dapat diinterpretasikan sebagai proses modemisasi untuk "membebaskan" kejumudan umat pada masa kini berdasarkan tradisi pemikiran masa lalu untuk direaktualisasikan sesuai dengan tuntutan zaman yang dilandasi keimanan dan etika Islam, yakni dari tradisionalis ke modernis, dari skriptual ke substansial, atau dari tekstual ke kontekstual.

Seperti di bidang keilmuan lainnya, beberapa pemikiran Madjid khususnya di dalam politik Islam, ia lebih mementingkan substansi daripada simbol-simbol formal keparatain. Jargon politiknya di tahun 1970-an, "Islam, Yes; partai Islam, No" merupakan salah satu refleksi model pendekatannya. Menurut Madjid, semboyan yang ia pertahankan sampai sekarang (1992-pen.) tersebutbenar adanya. Bahkan setelah selang dua dasawarsa, semboyan yang mirip sekali diperkenalkan oleh dua orang futurolog, John Naisbitt dan Patricia Aburdene, yang berkenaan dengan masalah agama "Spirituality, Yes; Organized Religion, No"
(John Naisbitt dan Patricia Aburdene, 1991, dalam Madjid, 1993: 8).

Tentang perlunya pembaruan pemikiran Islam, di bagian akhir makalahnya "Penyegaran Paham Keagamaan di Kalangann Generasi Muda Mendatang" yang disampaikan dalam acara memperingati 20 tahun pembaruan Islam di Taman Ismail Mazuki, Jakarta, 21 Oktober 1992 Madjid mengemukakan:

"Untuk dapat melakukan itu semua (pembaruan tradisi pemikiran-pen.) amat diperlukan usaha-usaha pengkayaan intelektual (intellectual encrichment), baik tentang masa lalu, masa kini, maupun perkiraan masa depan. Dan karena khazanah Islam di masa lalu sedemikian kayanya, maka salah satu usaha pengkayaan intelektual itu ialah dengan membaca kembali, memahami dan memberikan apresiasi yang wajar kepada warisan budaya umat. Tetapi (apabila-pen.) pembacaan dan pemahaman masa lalu hanya untuk mencari otoritas adalah tidak benar, sebab masa lalu tidak selamanya absah dan otentik. Sejarah, termasuk sejarah pemikiran, harus dipahami secara kritis, dalam kerangka dinamika faktor ruang dan waktu yang menjadi wadah atau lingkungannya. Pandangan kepada masa lalu sebagai dengan sendirinya absah dan otentik, sambil meninggalkan sikap krits kepada fakta historisnya, adalah pangkal sikap tertutup, konservatif, dan beku yang justru amat berbahaya. Tetapi pemahaman kepada masa lalu secara kritis dan dinamis, disertai apresiasi ilmiah yang adil, akan menjadi pangkal tolak pengkayaan intelektual yang subur dan produktif. Sebab manusia tidak mungkin menciptakan segala sesuatu dalam budayanya mulai dari nol setiap saat. Manusia bagaimana pun harus mengembangkan unsur-unsur warisan masa lalu yang sehat, dengan digabungkan kepada unsur-unsur baru yang lebih sehat lagi. Tidak adanya 
kontinuitas kultural dan intelektual masa sekarang dengan masa lalu akan mengakibatkan pemiskinan (impoverishment) kultural dan intelektual; dan pemahaman masa lalu secara dinamis, kritis dan dalam semangat penghargaan yang adil dan wajar adalah yang amat diperlukan untuk pengkayaan kultural dan intelektual guna memperoleh pijakan konfidensi baru yang kukuh menghadapi masa depan.

Jadi yang amat kita perlukan ialah kembali kepada makna dalil lama kaum ulama: Memelihara yang lama yang baik, dan mengambil yang baru yang lebih baik. Itulah keterbukaan yang dinamis, dan itulah jalan untuk membuat sebuah generasi menjadi kaya gagasan (resourcefull) untuk menghadapi segala tantangan zaman. Dan secara nasional, yaitu dalam konteks Indonesia, ... (?, kalimat terputus, pen.). Dengan begitu diharapkan Islam akan tampil lagi untuk memerankan dirinya sebagai faktor yang membawa demokrasi, modernisasi dan civilisasi bangsa" (Madjid, 1993: 21-22).

Gagasan pembaruan Madjid amat jelas dalam deskripsi di atas. Untuk melakukan pembaruan pemikiran diperlukan inovasi dalam proses pengayaan intelektual berdasarkan warisan budaya masa lalu yang dianggap baik untuk membangun kekayaan intelektual pada masa kini dan yang akan datang yang lebih baik. Inilah kontinuitas tradisi pemikiran dalam membangun pembaruan intelektual Islam.

Salah satu gagasan pembaruan pemikiran di bidang politik dari kalangan "modemis" cendekiawan Muslim Indonesia adalah pendekatan rasionalistik-realistiksubstantivistik. Hal ini sangat kontras dengan model yang dikembang-kan kalangan "tradisionalis" yang lebih menekankan terhadap pendekatan skriptualistik-idealistik- formalistik. Kelompok modernis cenderung mementingkan "isi", sedangkan kelom-pok tradisionalis lebih mementingkan "bentuk".

Dalam melakukan revitalisasi Islam dan politik, kalangan "modernis" cenderung menganggap tidak terlalu penting masalah bentuk kenegaraan dengan catatan ajaran, etika, dan moral Islam dapat eksis dan dijunjung tinggi, sedangkan kalangan "tradisionalis" mensyaratkan bentuk "negara Islam" dan konstitusi berdasarkan syari'at. Berkaitan dengan hal ini, Azyumardi Azra mengemukakan:

"Melihat pengalaman historis masyarakat-masyarakat kebangsaan Islam, khususnya di Timur Tengah, harus diakui amat sulit untuk menunjuk secara tegas dan tepat negara yang betul-betul merupakan representasi dari konsep dan sistem "negara Islam". Perkembangan yang diungkapkan di atas menjelaskan bahwa Islam pada akhirnya tidak menjadi faktor terpenting dalam konsep dan sistem kenegaraan dan politik. Pada gilirannya, Islam tidak pula menjadi pertimbangan pokok dalam kultur politik dan pengambilan kebijaksanaan. Meskipun demikian, perlu dicatat bahwa Islam sebagai suatu sistem kepercayaan tidak pernah kehilangan signifikasinya" (Azra, 1993: 15).

Hal tersebut dipertegas Ahmad Syafii Maarif berikut:

"Akibat langsung dari iklim politik imperial Islam itu, negeri-negeri Muslim yang memperoleh kemerdekaan pada abad ini menjadi bingung dalam menentukan sistem politik yang akan dilaksanakan. ... Di Indonesia ide Negara Islam harus berhadapan dengan ide Negara Nasional berdasarkan Pancasila. Akhirnya melalui Dekrit 5 Juli 1959 ide Negara Islam "dikalahkan" (dalam Piagam Jakarta, pen.), sementara dasar Pancasila dimenangkan. ... Para cendekiawan Muslim yang muncul sejak 1970-an (kalangan pembaru; substansialis- 
modernis yang dimotori Nurcholish Madjid, pen.) telah menerima dengan mantap ide Negara Nasional berdasarkan Pancasila, baik secara teoritis maupun dalam praktek. Perjuangan selanjutnya adalah menjadikan Negara Pancasila itu sebagai kendaraan untuk mewujudkan suatu tata sosio-politik yang adil, demokratis, dan egaliter, di atas landasan moral-transendental" (Maarif, 1993: 3).

Demikian pula dalam aktualisasi kepartaian; kelompok "modemis" cenderung mengedepankan "substansiasi" agama ke dalam proses politik, sedangkan kelompok "tradisionalis" cenderung mengede-pankan simbol-simbol formal institusi atau lembaga kepartaian (partai politik) dalam proses aktualisasi agama. Azyumardi Azra mengemukakan:

Demikian pula dalam aktualisasi kepartaian; kelompok "modemis" cenderung mengedepankan "substansiasi" agama ke dalam proses politik, sedangkan kelompok "tradisionalis" cenderung mengede-pankan simbol-simbol formal institusi atau lembaga kepartaian (partai politik) dalam proses aktualisasi agama. Azyumardi Azra mengemukakan:

"Agama tidak efektif dipakai dalam politik. Peningkatan penggunaan simbol dan konsep Islam akhir-akhir ini membuktikan bahwa agama tetap potensi penting dalam perkembangan politik Indonesia. Meskipun masuknya dalam kancah politik menjadi gejala global, sejumlah indikator memperlihatkan tren politik Indonesia tidak efektif menggunakan agama dalam politik. Paling tidak, Pemilu 1999 dan 2004 memperlihatkan rendahnya suara partai Islam. ... Problem kedua, keinginan untuk menerapkan syari'ah Islam berbenturan dengan komplikasi politis, legal-konstitusional, dan kultural-sosiologis."

Kalangan modemis-rasional yang dimotori Nurcholish Madjid, dkk. memperoleh tentangan yang kontras dari kalangan tradisionalis-skriptual, seperti dari aktivis dan cendekiawan Dewan Dakwah Islamiyah Indonesia (DDII) melalui "corongnya" Media Dakwah (MD). MD dan DDIl menurut R. William Liddle (1993: 55--59) merupakan cerminan Muhammad Natsir; seorang pimpinan Masyumi yang pernah ikut mendukung pemberontakan PRRI dan pendukung utama ide Negara Islam pada masa Demokrasi Parlementer (1950-an). Liddle menjelaskan, bagi pemimpin-pemimpin politik Orde Baru, mengangkat masalah Negara Islam atau yang semacamnya adalah sesuatu yang tabu. Tapi bagi MD, ide Negara Islam itu tetap hidup, meski diungkap secara hati-hati (halaman 57).

Kedua kelompok ini sering melakukan "perang" pemikiran yang sangat tajam. Menurut Ade Armando dalam tulisannya "Citra Kaum Pembaru Islam dalam Propaganda Media Dakwah"; misalnya, MD mencurigai Nurcholish Madjid tidak berdasarkan pada pandangan-pandangan yang sebenarnya, seperti dicurigai melakukan konspirasi dengan Yahudi, antek Barat bahkan disebut "neoMarxis" (Armando, 1993: 66-76). MD melihat Islam saat ini berada dalam kebangkitan sehingga musuh-musuh Islam termasuk Nurcholish Madjid sendiri mesti menyesuaikan diri dengan kekuatan baru Islam ini; MD mengklaim bahwa "secara keseluruhan tidak ada yang baru dari pemikiran Nurcholish, karena pemikiran-pemikiran semacam itu telah lama dikembangkan oleh kaum Yahudi di Indonesia (Liddle, 1993:56-57).

\footnotetext{
${ }^{8}$ Azyumardi Azra, dalam HU Kompas, 1 Mei 2006, hlm. 2, dikemukakan dalam diskusi di Universitas Paramadina, Jakarta.
} 
Terhadap kalangan substansialismodernis, Liddle merasa optimis dan berbeda pandangan; misalnya, dengan Clifford Geertz (1967, dan 1990) yang merasa pesimis terhadap posisi kaum substansialis-modernis yang semakin merosot. Menurut Liddle (1993: 53 -65) ide-ide kalangan substansialis lebih berpengaruh daripada kalangan skriptualis di dalam maupun di luar masyarakat Islam Indonesia, walaupun Liddle tidak secara tegas bahwa Orde Baru menjadi penyebab langsung atau bahkan prasyarat bagi kemunculan pembaru ini. Demikian pula dalam konteks pasca-Orde Baru, Lidlle tidak secara tegas berargumen apakah ide-ide kalangan pembaru ini masih dapat dipertahankan atau tidak dalam menghadapi Islam politik yang terus sedang berubah secara dramatis.

Menurut Liddle, ada empat gagasan pokok dari kaum substansialis yang saling terkait, yakni pertama, yang paling mendasar adalah bahwa substansi atau kandungan iman dan amal lebih penting daripada bentuknya. Kaitan dengan ini, Liddle memberi contoh mematuhi perintah al-Qur'an secara literal, termasuk yang berkaitan dengan rukun Islam, nilainya kurang positif dibandingkan berperilaku secara bermoral dan etis sesuai dengan semangat al-Qur'an. Kedua, pesan alQur'an dan hadis, yang tidak mengalami perubahan karena perubahan zaman dan esensinya bersifat universal, haruslah ditafsirkan oleh generasi selanjutnya (dalam pengembangan iitihad, fiqih, dan tradisi pemikiran, pen.) sesuai dengan kondisi yang ada pada waktu itu. Kaum substansialis telah menggunakan sejumlah terma untuk menggambarkan penerapan prinsip-prinsip itu bagi Islam Indonesia akhir abad ke-20 ini, yakni sekulerisasi, desakralisasi, reaktualisasi, dan pribumisasi. Ketiga, kaum Muslimin perlu toleran terhadap kalangan non-Muslim. Dan keempat, kaum Muslimin substansialis menerima struktur pemerintah sekarang sebagai bentuk final dari negara Indonesia, terutama Pancasila dan UUD 1945 yang dianggap sesuai dengan prinsip politik Islam.

Terhadap kebijakan-kebijakan politik rezim Soeharto, respon kaum substansialis lewat jargon, "Islam, Yes; Partai Islam, No" , diterima pemerintah. Efek positif yang diterimanya di antaranya semakin bertambahnya populasi santri yang terdidik. Generasi Nurcholish Madjid merupakan generasi pertama yang diuntungkan dengan meluasnya kesempatan pendidikan ini. Sebaliknya, kalangan skriptualis sejak awal tidak diuntungkan oleh sistem karena mereka tetap ingin menerapkan syari'ah (Liddle, 1993: 59-61). Pada masa Orde Baru sejumlah generasi muda Muslim memperoleh kenikmatan untuk mengenyam pendidikan tinggi dalam dan luar negeri pada perguruan tinggi yang sangat menonjol, seperti Amien Rais, Ahmad Syafii Maarif, Kuntowijoyo, Yahya Muhaimin, Ahmad Watik Pratignya, Umar Anggoro Jeni, Jamaluddin Ancok, Sofian Effendy di Yogyakarta; Abdurrahman Wahid, Nurcholish Madjid, Johan Effendi, Amin Azis, Dawam Rahardjo, Adi Sasono, Sri Bintang Pamungkas, Aswab Mahasin; di Bogor di antaranya A. M. Saefuddin, dll. Dari generasi ini tumbuh persepsi baru hubungan Islam dan negara tidak lagi memperjuangkan Islam sebagai ideologi negara, tetapi mereka melakukan hubungan akomodasi politik dan low profile dalam membina komunikasi politik dengan non-Muslim dan Angkatan Bersenjata (Gaffar, 1993:22-23).

Inilah model hubungan "simbiosis mutualisma" yang dilakukan para pembaru; mereka tidak menggunakan formalisme pendekatan kepartaian secara langsung, tetapi lebih mementingkan "isi" daripada "bentuk". Oleh Liddle kelompok pembaru inilah yang disebutnya sebagai kaum substansialis. 
Selanjutya Liddle (halaman 61-65) memprediksikan, ada tiga faktor yang bisa mendorong kuatnya posisi kaum skriptualis, terutama jika iklim politik pasca-Soeharto lebih terbuka, yakni pertama, lebih diterimanya doktrin skriptualis oleh kebanyakan kaum Muslim Indonesia, seperti al-Qur'an adalah kalam Illahi yang harus ditangkap secara literal; Islam mencakup seluruh kehidupan (termasuk terintegrasinya Islam dan politik, pen.).. Hal ini akan ditunjang potensi pertumbuhan pendidikan santri yang kebanyakan tinggal di pedesaan, berkembangnya popularitas kursus-kursus al-Quran (dan pendidikan ke-Islam-an lainnya, pen.) di kampus-kampus pada kalangan mahasiswa, dan meningkatnya pengalaman keagamaan kalangan sufisme. Kedua, kemugkinan beraliansinya kaum skriptualis dengan kelompok-kelompok lain, seperti dengan kelompok kelas bawah yang dicitrakan bermusuhan dengan birokrat, militer, pengusaha keturunan Cina, perusahaan asing (terutama Barat), yang sering disampaikan skriptualis seperti melalui MD atau beraliansi dengan kelompok-kelompok pengusaha dan birokrat yang tidak puas terhadap pemerintah. Selan itu, kemungkinan beraliansi dengan orang yang menginginkan otonomi daerah yang selama Orde Baru pembangunan perekonomian terpusat di Jakarta, terutama dari daerah-daerah yang pernah mendukung "pemberontakan" Masyumi (dalam PRRI, pen.). Ketiga, keinginan para politisinya yang ambisius untuk membangun basis massa. Hal ini bertitik tolak dari kemungkinan semakin banyaknya politisi pasca-Orde Baru yang ambisius berkuasa yang memerlukan basis massa Islam seperti yang dilakukan Orde Baru dengan kebijakan politik mendorong tumbuhnya keshalehan ummat tetapi menentang politik Islam, seperti yang terjadi mulai tahun 1980-an.
Selain konsep tersebut, memasuki tahun 1995-an, muncul pemikiran tentang pembaruan Islam dari Herman Soewardi dengan konsep Adab-Karsa. Konsep AdabKarsa Herman Soewardi dalam buku Mempersiapkan Kelahiran Sains Tauhidullah (2001b), dikembangkan dari teori David McClelland (1961) tentang "culture and personality". Teori McClelland ini kemudian ia hubungkan dengan teori Myrdal, tentang "hard" dan "culture". Pada masyarakat dengan $n$-ach tinggi atau "achieving society", terdapat "hard culture", dan pada masyarakat yang "non-achieving society" terdapat "softculture".

Selain dari kedua orang tersebut, Soewardi pun dipengaruhi oleh pemikiran Herbert Mead, Znaniecki, Robert K. Merton, dan Eric Fromm. Dari pandangan-pandangan terpenting McClelland, Myrdal, Herbert Mead, Znaniecki, Merton, dan Eric Fromm; di satu pihak, dan sejarah Nabi Muhammad SAW; di lain pihak, Soewardi mencetuskan konsep Adab-Karsa khususnya dalam memandang keadaan sosio-kultural komunitas masyarakat Islam dengan dasar logika substitutabel (bukan necessary). Menurutnya, adab menunjukkan ketaatan masyarakat terhadap perintah-perintah Tuhan (yang bisa tinggi dan bisa rendah), dan karsa menunjukkan kekuatan psikologis (bisa kuat dan bisa lemah) masyarakat untuk mencapai yang diinginkannya. Karenanya, timbul Adab Tinggi dan Adab Rendah, dan Karsa Kuat dan Karsa Lemah. la menunjukkan bahwa timbultenggelamnya sivilisasi itu berlatar belakang pada adab-karsatersebut.

Kekelinuan persepsi teologis tentang Islam, menimbulkan lima sifat dasar kelemahkarsaan, yaitu 1) tidak ada orientasi ke depan; 2) tidak ada growth philosophy, 3) cepat menyerah; 4) berpaling ke akhirat (retreatism); dan lamban atau inertia.

Ada beberapa pokok pikiran teori sosiologi politk Herman Soewardi yang dapat 
dijadikan pegangan, di antaraya: pertama, Indonesia pasca-Orde Baru sedang dilanda pelapukan politik, disintegrasi bangsa, dan keberantakan ekonomi (Soewardi, 2001b:80). Kedua, kekalahan kaum Muslimin (partai politik Islam) di Indonesia pada Pemilu tidak terlepas dari "kekalahan" kaum Muslimin Indonesia sebelumnya yang sudah kita lihat sejak empat abad lalu dengan terjadinya perubahan "budaya pantai" (perdagangan) di zaman Kerajaan Demak ke "budaya pedalaman" (agraris) yang terisolir pada zaman Kerajaan Mataram. Mengapa hal tersbut terjadi dan bagaimana jalan pemecahannya, la menganalisisnya dengan pendekatan inkonvensional (transendentaldeduktif), bukan melalui pendekatan konvensional (empirikal-deduktif).

Menurut Soewardi, Mataram mewujudkan sistem parternalistik dengan hirarki yang ketat. Di samping itu, mengakibatkan hilangnya "Weisya Culture" atau budaya dagang, sehubungan Mataram harus unggul terhadap bangsawan pantai yang hidup dari perdagangan. Sistem paternalistik merupakan hubungan dengan atas desa (raja), maka hubungan sudra dengan ksatria. Kelas menengah atau weisya atau pedagang yang bersifat dinamik dan egaliter dengan demikian menjadi tidak berkembang. Orang-orang Timur Asing difungsikan oleh Belanda untuk melakukan perdagangan dengan interior, suatu rentang yang kita rasakan sampai sekarang.

Sistem paternalistik tersebut sangat menerpurukkan inisiatif dan kreativitas rakyat sehingga mengidap penyakit Lemah Karsa, baik dalam mobilitas horizontal maupun mobilitas vertikal. Menghendaki loyalitas mutlak, tanpa kreativitas, dan tanpa business culuture merupakan akibat lain dari budaya Mataram tersebut. Dengan demikian; menurut Soewardi, dalam game theory-nya, umat Islam harus meninggalkan status quo.
Menurut Soewardi, kekalahan partaipartai Islam pada Pemilu 1999; yangpada sisi lain banyak yang meremehkannya, namun bagi dirinya justru kekalahan tersebut sebagai kunci (titik tolak, pen.) ke arah pemahaman kita tentang Islam (termasuk politik, pen.) di Indonesia ke arah yang lebih baik. Kekalahan tersebut disebabkan oleh "Islamo-phobie" (takun akan Islam) bahkan dapat dikatakan "tidak menyukai Islam". Islam banyak dikonotasikan negatif; seperti peraturanperaturan yang ketat, tidak boleh bersenangsenang, dan hukuman-hukuman yang berat. Mereka memandang bahwa Islam membenamkan mereka di dalam keterpurukan, kemiskinan, dan kebodohan. "Image" tentang Islam adalah: "kopeah dilelepkeun, sarung belel, dan mata belek". Jelas hal tersebut salah pandang tentang Islam, sehingga perlu mengubah struktur kognitif tentang Islam melalui penelusuran sejarah (dan belajar dari masa keemasan, pen.) Islam.

Dalam konteks sosiologi politik, pemikiran Soewardi tersebut dapat ditafsirkan bahwa umat Islam perlu melakukan reorientasi teologi, dari pendekatan empirikal-induktifpositivistik-weternisasi ke pendekatan transendental-deduktif-Qur'ani sebagaimana "kemajuan ideal" pada "tujuh abad yang benar" masa Rasulullah SAW. Kekalahan partai-partai Islam pada masa yang lalu, hendaknya disikapi oleh human motivationtransendentalistik melalui kognisi baru dengan

Karsa Kuat-Adab Tinggi yang mengedepankan harmoni sosial (integrasi) dalam membangun tatanan politik-ideologis sebagaimana dicontohkan Rasulullah SAW.

\section{Konflik dan Integrasi}

Dalam Islam, terminologi konflik diartikan sebagai ikhtilaaf (perbedaan, perselisihan, pertukaran, berlain-lainan). Kata ikhtilaaf digunakan dalam Al-Quran, seperti di dalam surah Al-Baqarah ayat 213 dan 253, surah 
Aali Imraan ayat 105, surah An-Nisaa ayat 157, surah Yuunus ayat 93, serta surah AnNahl ayat 39, 64, dan 124. Dalam sebuah hadis Rasulullah SAW bersabda, "Ikhtilaaf ummati rahmah" yang artinya perbedaan pendapat (di kalangan) umatku adalah rahmat (H. R. Al-Baihaki). Selain kata ikhtilaaf, dalam terminologi Islam, dikenal pula istilah iftiraaqun (perpecahan) danan-nizaau (persengketaan). Menurut lbn Khaldun (1377), agama mempunyai pengaruh terhadap kekuatan negara. Jika pertikaian (konflik) terjadi di kalangan penguasa, maka negara pun akan lemah, cepat hancur, dan musnah (Khaldun, dalam Ralliby, 1962: 41). IImu politik menghendaki agar hanya (ada) satu penguasa saja yang mengendalikan pemerintahan. Jika banyak orang, maka akan menimbulkan kehancuran suatu pemerintahan (Khaldun, 1962: 222). Pimpinan politik memerlukan bantuan dari orang-orang di sekitarnya. Seorang pimpinan politik hendaknya mampu mengendalikan konflik dan stabilitas keamanan, mampu mengawasi, meningkatkan kesejahteraan masyarakat serta mampu mempengaruhi masyarakat secara psikologis (Khaldun, 1962: 229-230). Tujuan akhir dari solidaritas sosial ('ashabiyah) adalah kedaulatan (al-mulk). Jika tidak ada satu solidaritas sosial yang lebih kuat dari seluruh solidaritas yang ada, maka perpecahan, pertikaian, dan pertentangan (konflik) antar-kelompok solidaritas sosial tidak

bisa dihindari. Akibatnya, kedaulatan tidak akan tercapai (Khaldun, 2000: 166). Lebih jauh ia mengemukakan:

"Satu di antara akibat-akibat lazim dari organisasi kemasjarakatan itu adalah pertikaian (at-tanaazuu) jang disebabkan oleh tekanan-tekanan dari pendapat-pendapat jang berbeda-beda (at-tanaazuu li izdihaam alaghraadh). Selama tidak ada penguasa jang akan melaksanakan sesuatu kewibawaan, maka pertikaian ini akan menimbulkan keributan atau kekatjauan, jang seterusnja dapat mengakibatkan penghantjuran dan pemusnahan manusia. Karena itulah maka pemeliharaan djenis umatmanusia adalah salah satu dari maksud-maksud jang daruri (sangat penting) dari Sjari'at Islam" (Khaldun, 1962: 166).

Konflik bisa terjadi akibat dari tidak terkendalinya kekuasaan, ketamakan, berlaku zalim, tidak adil, dan agresif (merampas hakhak orang lain) yang didasari oleh rasa amarah dan rasa benci. Agar masyarakat tidak berkonflik dan bertindak anarki, maka memerlukan pemerintahan yang dipimpin oleh seseorang yang memiliki kekuasaan wibawa untuk mengendalikannya (Khaldun, 1962: 215-216). Kekuasaan wibawa perlu dipusatkan pada tangan satu orang yang kuat dan mampu mengendalikan kepemimpinan (Khaldun, 1962: 220-221). Semangat agama bisa meredakan pertentangan (konflik) dan iri hati serta akan menuntun manusia ke arah kebenaran sehingga dapat mempersatukan (mengintegrasikan) pandangan dan tujuan mereka (Khaldun, 2000: 192-193). Namun, gerakan keagamaan tidak akan berhasil tanpa solidaritas sosial yang kuat (Khaldun, 2000: 194). Untuk mengeliminir konflik, Khaldunmenjelaskan:

"Untuk meniadakan pertentangan (tanazu') cukuplah setiap orang mengetahui bahwa kezaliman diharamkan atasnya berdasarkan hukum akal. Dengan demikian, dugaan mereka (sebagian filosofilmuwan) bahwa pertentangan hanya mungkin ada dengan adanya syari'at di satu sisi, dan kedudukan imam di sisi lain, tidaklah benar. Pertentangan itu dapat dilenyapkan, baik dengan adanya kekuatan para pemimpin atau dengan usaha rakyat menjauhkan diri dari pertikaian dan saling berlaku zalim, maupun dengan adanya jabatan imam tersebut. Dengan demikian, dalil aqli (akal) yang didasarkan kepada premis itu tidak tahan uji. 
Maka dengan itu teranglah keharusanadanya imam diindikasikan oleh syariat melalui konsensusatau ijma" (Khaldun, 2000:236).

Konflik bisa disebabkan oleh perbedaan ijthad. Menurut Khaldun:

"Harmoni dan solidaritas sosial benar-benar memainkan peranan di sana (dalam komuitas Islam). Solidaritas sosial merupakan faktor rahasia Illahi yang mengendalikan rakyat supaya tidak terpecah belah dan bermusuhan (berkonflik). Solidaritas sosial adalah sumber persatuan dan kesepakatan (integrasi) serta penjamin dari tujuan dan syari'at agama Islam. Peperangan dan perpecahan di antara para sahabat dan tabi'in, hanyalah persoalan agama dan timbul dari iithihad. Perselisihan pasti muncul di kalangan orang yang berijtihad. Puncak perselisihan yang terjadi di antara para sahabat dan tabiin adalah perselisihan aiithid mengenai masalahmasalah agama yang belum jelas" (Khaldun, 2000:263-264).

Sedangkan menurut perspektif teori Barat, masyarakat manusia sebagai sebuah proses perkembangan akan menyudahi konflik melalui konflik (Marx; dalam Campbell, 1999: 134). Menurut Max Weber (18641920), konflik adalah sebuah bentuk hubungan yang di dalamnya mengandung tindakan yang sengaja diarahkan untuk melaksanakan kehendak si pelaku sendiri untuk melawan serangan partai atau partaipartai lain (Campbell, 1999: 211). Konflik adalah mekanisme yang mendorong perubahan. Hubungan antara konflik dan perubahan cenderung menjadi satu proses yang berlangsung dengan sendirinya terus menerus (Smeslund, 1961; dalam Lauer, 1993: 287--290)." Tampak adanya hubungan erat antara konflik dan perubahan (Dahrendorf, 1959: 208, dalam Lauer 1993: 281). Sesuatu yang ada, ditandai oleh kesatuan dan konflik dengan lawannya; ditandai oleh kontradiksi; kontradiksi menjadi sifat dari alam maupun masyarakat (Lauer, 1993: 90). Konflik dan integrasi bukanlah dua aspek yang kontradiktif di dalam politik; keduaduanya saling melengkapi (Duverger, 1998: 251). Teori konflik lebih memusatkan perhatiannya pada perbedaan, ketegangan, dan perubahan (Horton \& Hunt, 1996: 21).

$$
\text { Herman Soewardi menentang }
$$
pandangan ilmuwan Barat bahwa yang membawa kemajuan manusia adalah konflik: la mengemukakan:

"Menurut ideologi Marxis, yang membawa kemajuan manusia adalah konflik (bukan harmoni atau "brotherhood') dan justru dengan harmoni semangat manusia menjadi lemah. Asas konflik ini oleh Adam Smith "diperas" menjadi self-interest, yakni kepentigan-kepentingan diri manusia yang menjadi motor penggerak kemajuan. Pandangan self-interest Smith pun bertentangan dengan achievement motivation dari McClelland (Soewardi, 2003: 8-17). Menurut pandangan Barat, konflik itu asas yang merupakan sifat dasar manusia, dan karena itu tidak bisa mengkonsepsikan suatu sistem ekonomi tanpa konflik. Justru konflik itulah menurut mereka sebagai pendorong ke arah kemajuan (Soewardi, 2001: 58). Berbeda dengan pandangan tersebut, McClelland dalam The Achieving Society (1961) manusia maju bukan karena konflik, tetapi karena faktor motivasi berupa need for achievement atau kebutuhan berprestasi" (Soewardi, 2001:63).

Sementara itu, Juhaya S. Pradja mengemukakan:

"Menurut aliran teori konflik, masyarakat yang baik dan sehat adalah masyarakat yang hidup dalam situasi konfliktual. Masyarakat yang berada dalam keseimbangan (equilibrium) dianggapnya sebagai masyarakat yang tertidur dan berhenti dalam proses kemajuan. Karena konflik atau bentrokan sosial dianggapnya sebagai kekuatan utama dari 
perkembangan masyarakat yang ingin maju ke tahap-tahap yang lebih sempurna. Dalam konteks ini, pengaruh perilaku agama yang dianggap memiliki "daya disintegratif', menjadi positif (Pradja, 2000: 45)."

Menurut bentuknya, konflik terdiri atas konflik vertikal dan konflik horizontal. Dalam konteks penelitian ini, konflik vertikal adalah konflik antara pemerintah (negara) dengan partai politik, sedangkan konflik horizontal adalah konflik antar-partai politik. Berdasarkan sifatnya, konflik dapat dibedakan menjadi konflik terbuka dan konflik tertutup (latentif).

Jenis-jenis konflik terdiri atas (1) konflik pribadi; (2) konflik sosial (budaya, ekonomi, suku, agama, rasial, golongan/kelompok, kelas sosial, dll.); (3) konflik politik atau kekuasaan, dll. Konflik politik, merupakan fokus utama yang akan dikaji dalam penelitian ini.

Konflik ada yang fungsional dan yang tidak fungsional terhadap perubahan. Menurut Sutrisno (2003: 14-16) konflik fungsional adalah konflik yang menghasilkan perubahan atau konsensus baru yang bermuara pada perbaikan. Menurut Tadjudin (2000: 36) konflik fungsional adalah konflik yang mendukung terhadap pencapaian tujuan dan mampu meningkatkan kinerja kelompok. Sedangkan konflik disfungsional adalah konflik yang menghambat kinerja kelompok. Dari dua pendapat tersebut; dalam konteks perubahan, dapat diinterpretasikan bahwa konflik fungsional adalah konflik yang menghasilkan perubahan sosial ke arah yang positif, sedangkan konflik yang disfungsional adalah konflik yang tidakberpengaruh positif terhadap perubahan sosial. Dengan demikian; berdasarkan fungsinya, konflik dapat dibedakan menjadi konflik fungsional dan konflik disfungsional.

Menurut Fisher, dkk. (2001: 8-9), konflik dapat disebabkan oleh (1) polarisasi yang terus terjadi, ketidakpercayaan, dan permusuhan dalam kelompok masyarakat; (2) ketidakselarasan posisi dan perbedaan pandangan; (3) tidak terpenuhinya kebutuhan; (4) keterancaman identitas atas peristiwa masa lalu yang tidak terselesaikan; (5) ketidakcocokan budaya; dan (6) ketidaksetaraan dan ketidakadilan. Selain itu, konflik pun dapat disebabkan perbedaan persepsi, pengetahuan, tata nilai, kepentingan, dan pengakuan hak kepemilikan (Tadjudin, 2000: 39); atau disebabkan oleh sentralisme kebijakan pemerintah (Adimihardja, 2000: 59).

Dampak konflik bisa bersifat fungsional (positif) dan disfungsional (negatif). Menurut Soekanto (2002: 112-113), konflik yang positif dapat meningkatkan keeratan solidaritas in-group suatu kelompok; sedangkan dampak negatif konflik mengakibatkan retaknya persatuan kelompok, perubahan kepribadian individu karena tekanan mental, hancurnya harta benda dan korban manusia, serta timbulnya akomodasi (apabila pertikaian seimbang), dominasi (apabila pertikaian tidak seimbang), dan takluknya salah satu pihak (apabila salah satu pihak kalah berkuasa).

Resolusi konflik berarti menangani sebab-sebab konflik (Fisher, dkk.: 2001: 7). Konflik perlu dikelola dan dikendalikan sehingga dapat menciptakan dinamika sosial yang positif (Johnson, 1989: 138). Menurut Margono (2004) dan Usman (2003) dalam Nulhaqim (2005), cara penanganan konflik dapat secara konvensional, yakni secara litigasi (di muka pengadilan) atau dengan cara non-litigasi, yakni melalui ADR (Alternatif Dispute Resolution). Penyelesaian konflik model ADR menekankan terhadap proses negosiasi (kesepakatan melalui proses interaksi langsung antar-pihak yang bertikai), mediasi (kesepakatan yang melibatkan pihak ketiga sebagai mediator atau penengah; mediator bersifat aktif), konsiliasi (kesepakatan yang melibatkan pihak ketiga sebagai konsiliator; konsiliator bersifat pasif, dan 
arbitrasi (kesepakatan yang melibatkan pihak ketiga sebagai arbitrator; arbitrator harus netral dan disepakati kelompok yang bertikai, mempunyai wewenang untuk memutuskan, dan keputusannya bersifat mengikat pihakpihak yang bertikai).

Dalam konteks integrasi politik, teori interaksi simbolik pun dapat dijadikan salah satu sandaran untuk menganalisis dinamika gerakan partai politik (Islam): apakah ia konsisten (istiqamah) di "dunia nyata" atau tidak. Teori interaksi simbolik yang berasal dari filsafat pragmatisme yang kemudian dikembangkan George Herbert Mead ini memandang bahwa realitas sebenamya tak berada "di luar" dunia nyata; bila kita ingin memahami aktor, kita harus mendasarkan pemahaman itu di atas apa-apa yang sebenarnya mereka kejjakan dalam dunia nyata (Ritzer \& Goodman, 2005: 266). Oleh Irving Goffman (1959) teori interaksi simbolik dikembangkan menjadi konsep dramaturgi, yakni pandangan tentang kehidupan sosial sebagai serentetan pertunjukan drama, seperti yang ditampilkan di atas pentas. Dramaturgi Goffman memperhatikan proses yang dapat mencegah gangguan atas penampilan diri. Dengan menggunakan analogi teatrikal, Goffman berbicara mengenai panggung depan (front stage) dan panggung belakang (back stage). Front stage yang terdiri atas setting dan front personal, dan front personal terdiri atas penampilan dan gaya. Dalam back stage, fakta disembunyikan di depan atau berbagai jenis tindakan informal lainnya yang mungkin timbul.

Teori dramaturgi Goffman dapat diinterpretasikan bahwa penampilan dan gaya seorang aktor di front stage, dapat berbeda dengan "dunia nyata" yang sesungguhnya terjadi di back stage. Seorang aktor yang berada di back stage dengan "dunia nyata"nya bukan seorang pemabuk dan shaleh, di dalam front stage ia harus mampu memerankan dan "memanipulasi" dirinya menjadi seorang pemabuk berat dengan wajah yang garang. Aktor tersebut berhasil mementaskan dan menyampaikan komunikasi simbolik "di luar" dunia nyata.

\section{Metode Penelitian}

Penelitian ini menggunakan metode kualitatif. Metode kualitatif; sebagai prosedur penelitian, menghasilkan data deskriptif berupa kata-kata tertulis atau lisan dari orangorang dan perilaku yang dapat diamati (Bogdan dan Taylor, 1975; dalam Moleong, 1997: 2-3). Metode kualitatif indikasinya tampak dari membiarkan sesuatu masalah itu dipecahkan oleh jawaban yang berasal dari alam itu sendiri. Pendekatan kualitatif dalam penelitian adalah untuk mencari kebenaran relatif (Garna, 1999: 29 dan 38). Bertitik tolak dari kedua pendapat tersebut, data-data kualitatif hasil pengamatan di lapangan, merupakan fenomena sebab-akibat sehingga sesuatu hal yang menjadikan timbulnya suatu peristiwa dapat teridentifikasi secara kualitatif.

Penelitian kualitatif mengacu pada strategi penelitian observasi partisipan dan wawancara mendalam, yang bertujuan untuk memahami aktivitas yang diselidiki, yang memungkinkan peneliti memperoleh informasi daritangan pertama mengenai masalah sosial empris yang hendak dipecahkan (Chadwick, et. al., 1988:235).

Dilihat dari maksud dan tujuannya, penelitian ini bersifat deskriptif (descriptive research) yang bertujuan untuk "menggambar dan memperoleh gambar" fenomena setepat realita (Rusidi, 1999: 18--19). Metode deskriptif bertujuan untuk membuat deskripsi, gambaran atau lukisan secara sistematis, faktual, dan akurat mengenai fakta-fakta, sifat-sifat serta hubungan antara fenomena yang diselidiki (Nazir, 1988: 63). Sedangkan menurut Withney (dalam Aminudin, 1999: 49) penelitian deskriptif adalah pencarian fakta dengan 
interpretasi yang tepat dengan tujuan untuk membuat deskripsi, gambaran atau lukisan secara sistematis, faktual, dan akurat mengenai fakta-fakta, sifat-sifat serta hubungan-hubungan antar-fenomena yang diselidiki.

Bertitik tolak dari ketiga pendapat tersebut, deskripsi atau gambaran hubungan antar fenomena yang akan ditelit dan dianalisis bersifat kausalitas (hubungansebabakibat). Oleh karenanya, peneliti berusaha menemukan kausa (sebab yang menimbulkan suatu kejadian) secermat mungkin tentang isu sentral yang akan diteliti yang kemudian akan dideskripsikan secara sistematis, logis, faktual, dan akurat.

Penelitian ini tidak melakukan pengujian hipotesis secara khusus. Penelitian deskriptif dimaksudkan untuk mengukur dengan cermat terhadap fenomena sosial tertentu; peneliti mengembangkan konsep dan menghimpun fakta, tetapi tidak melakukan pengujian hipotesis (Erickson dan Nosanchuk, 1977; dalam Singarimbun, Ed., 1995: 4--5).

Walaupun tidak melakukan pengujian hipotesis secara khusus, hipotesis kerja yang dirumuskan dalam penelitian ini tetap berfungsi sebagai pemandu penelitian (research guide). Artinya, fenomenafenomena sebab-akibat yang akan diteliti senantiasa mengacu dan berpatokan terhadap research guide tersebut (Soewardi, 2004a: 168).

Berdasarkan teori di atas, maka untuk memperoleh data empirik dari lapangan, penulis berusaha melibatkan diri ke dalam aktivitas keseharian masyarakat (melakukan observasi partisipasi) dan melakukan wawancara mendalam. Dengan cara demikian, berbagai fenomena politik yang berkembang di masyarakat; termasuk data yang tersebar di mass media cetak, dapat diperoleh secara objektif, memiliki kualitas dan validitas data yang lebih reliabel (terpercaya).
Data empirik hasil pengamatan dari lapangan tersebut selanjutnya akan dideskripsikan sehingga diharapkan dapat menghasilkan suatu rekonstruksi perubahan sosial politik Islam berdasarkan hasil berpikir induktif.

\section{Konflik dan Integrasi}

Berdasarkan hasil wawancara dengan informan kunci dan pengamatan partisipatif di lapangan, ada beberapa faktor internal yang mendorong konflik partai-partai Islam. Pertama, secara internal konflik terjadi karena berorientasi kekuasaan, fragmatis, dan lemahnya solidaritas. Beberapa informan kunci ${ }^{9}$ mengemukakan sebagai berikut: "Konflik internal dalam politik Islam mulai muncul setelah Nabi Muhammad SWT wafat, khususnya gerakan politik kekuasaan dari Muawiyah. Yang berkembang saat itu, bukan masalah perbedaan ajaran (furu'iyah) seperti qunut dalam shalat, ibadah haji, dll., melainkan masalah politik. Khusus di Indonesia, selain perbedaan dalam masalahfuru'iyah, berkembang juga konflik politik. Dalam Pemilu 1955, misalnya, terjadi konflik politik antara NU dan Masyumi. Pada masa Orde Baru, di internal NU terjadi pula konflik antara kalangan NU yang berorientasi politik dengan NU yang berorientasidakwah.

Secara internal, sejak dibentuknyapartai Islam menjelang Pemilu 1999, konflik politik antar-partai Islam tidak berlatar belakang perjuangan ideologis mumi, tepi lebih mengarah pada tujuan kekuasaan, berebut pengaruh, dan wibawa. Tidak hanyakalangan politisi, kalangan kiai pun ikut bermain politik. Tujuannya, agar memiliki akses dan dekat dengan kekuasaan. Kita lihat, pesantren yang maju di ada di Jawa Barat, misalnya, rata-rata

\footnotetext{
9la seorang wartawan bidang pendidikan dan agama di sebuah media massa yang cukup berpengaruh di Jawa Barat.
} 
yang dekat dengan kekuasaan dan birokrat. Fasilitas yang mereka terima tidak hanya dari partai atau tokoh Islam saja, pada pemerintahan Presiden Megawati, ada sebuah pesantren besar di Cillin, Kabupaten Bandung, misalnya, yang menerima sumbangan dari PDI-P. Demikian pula ada pesantren besar di Bandung Timur, selain ia dekat dengan politisi dan birokrat juga pernah menjadi pengurus dan anggota DPRD Jawa Barat dari Golkar. Hal yang sama dilakukan sebuah pesantren besar di Bandung Utara dimana kiai-nya sangat dekat dengan kalangan penguasa, bahkan ada seorang kiai yang memiliki pesantren besar di Bandung Barat, masuk sebagai anggota DPDRI. Jadi, secara internal, persaingan politik antar-partai Islam yang mengakibatkan konflik dilatarbelakangi kepentingan kekuasaan dan akses politik ke pusat kekuasaan, bukan atas dasar perjuangan ideologi, padahal Al-Qur'an Surat Ali 'Imran, Ayat 105 menjelaskan, "Dan janganlah kamu menyerupai orang-orang yang bercerai berai dan berselisih sesudah datang keterangan yang jelas kepada mereka. Mereka itulah orang-orang yang mendapat siksa yangberat'".

Data tersebut menunjukkan bahwa secara internal keterlibatan pesantrenpesantren tertentu pada politik kekuasaan bertujuan membuat jaringan ke pusat kekuasaan untuk kepentingan pragmatis dalam membesarkan lembaga yang dipimpinnya. Hal senada dikemukakan seorang informan kunci $^{10}$ berikut:

“... Saya pernah masuk di kelompok Nahdliyin. Ketika figur pucuk pimpinan di Nahdliyinmengajak semua umat Nahdliyin berafiliasi ke calon presiden " $X$ ", namun calon

\footnotetext{
${ }^{10}$ Informan ini adalah seorang aktivias LSM (Lembaga Swadaya Masyarakat) dan pengusaha, juga sering mengunjungi beberapa pesantren besar di Indonesia.
}

presiden $\mathrm{X}$ tersebut tidak dianggap baik oleh kelompok di bawahnya, maka kelompok ini membentuk kelompok baru Ketua MUI di Garut, misalnya, berafiliasi ke calon " $X$ ", Ketua NU berafilisasi ke " $Y$ ", umat di bawahnya yang tidak menyetujui terhadap calon " $X$ " dan " $Y$ ", berafiliasi ke calon "Z". ... Rupanya, para kiai yang sangat paham terhadap khittah, lebih mengedepankan pragmatis: apabila saya berafiliasi terhadap figur tertentu, apasih yang dapat saya peroleh untuk pengembangan pesantren saya? Hal-hal pragmatis seperti ini sekarang sudah menjadi tujuan pesantrenpesantren tertentu untuk membesarkan lembaga yang dipimpinnya. Pesantrenpesantren besar biasanya adalah mereka yang sudah bisa berdampingan dengan kekuasaan, dan itu terjadi sejak awal Orde Baru hingga hari ini masih berlangsung. ... Oleh pesantren-pesantren yang lebih kecil, terafiliasinya pesantren-pesantren besar terhadap kekuasaan tersebut diikutinya, karena dengan cara demikian mereka dapat memperbesar pesantrennya....".

Informan lainnya mengemukakan bahwa partai hanya dijadikan alat kekuasaan semata demi kepentingan pribadi dan kelompok, bukan untuk kepentingan membangun negara. Parpol hanya dijadikan elit sebagai sarana membangun popularitas elit melalui perolehan kursi legislatif. Seorang informan kunci, ${ }^{11}$ saat diwawancarai mengemukakan kepada peneliti sebagai berikut:

“... Menurut pendapat saya, tidak ada perbedaan antara konflik partai-partai Islam dan non-Islam (nasionalis sekuler dan yang sejenisnya), karena hal itu adalah persoalan pertarungan kekuasaan. Untuk meraih dan mempertahankannya kadang-kadang mereka melanggar Anggaran Dasar dan Anggaran

\footnotetext{
${ }^{11}$ la seorang akademisi dan Ahli Peneliti Utama dan Kepala Pusat Penelitian Politik, Lembaga IImu Pengetahuan (LIPI), Jakarta.
} 
Rumah Tangganya yang telah mereka buat sendiri. Jadi, penyebabnya sama, yaitu kekuasaan; yang satu ingin tetap mempertahankan kekuasaan, yang lainnya ingin merebut posisi kekuasaan. Kadangkadang masing-masing pihak mengatas namakan AD-ART, padahal keduanya samasama melanggar AD-ART. ..."

Senada dengan pendapat informan tersebut, informan lainnya yang cukup berpengaruh di lingkungan NU Kabupaten Garut $^{12}$ mengemukakan kepada peneliti sebagai berikut:

"Orientasi Partai-partai Politik Islam adalah kekuasaan, bukan untuk kepentingan umat secara luas, tetapi hanya untuk kepentingan pribadi para politisi saja. Perlu dilakukan peningkatan pemahaman dan orientasi Partai Politik yang tidak diarahkan terhadap kepentingan-kepentingan pribadi, tetapi umat secara menyeluruh. Kembalinya NU ke Khittah dalam Mukhtamar NU 2004 di Solo dan tidak berpolitik; termasuk mendukung PKB, intinya ingin mengembalikan fungsifungsi NU sebagai organisasi sosial masyarakat yang mengarah pada diniyah waiijtimaiyah atau kembali mempertahankan ajaran Islam dan kemasyarakatan yang tidak berorientasi politik dan kekuasaan, bahkan (menurut keputusan Mukhtamar NU tersebut) rangkap jabatan pun (di NU dan PKB) tidak dibolehkan. NU tidak diuntungkan, malah cenderung dirugikan secara politik atas dukungannya terhadap PKB. Tidak ada manfaatnya, yang terjadi malah banyak madhorot-nya yang mengakibatkan terceraiberainya umat. Lebih baik NU menjadi "garam" bagi setiap partai. Silakan umat NU di partai mana saja, dan sebaiknya menjadi perekat umat".

\footnotetext{
${ }^{12}$ Ia adalah Ketua Tanfiziyah NU Kabupaten Garut.
}

Berkaitan dengan hal tersebut, seorang aktivis $\mathrm{PKS}^{13}$ mengemukakan pendapatnya kepada penulis:

"...Jadi kalau menurut saya di satu sisi mungkin kalau ngomong demokratisasi itu baik, tetapi di sisi lain kultur yang begituparah, sebab ternyata perbedaan itu bukan perbedaan fiqih; sebagaimana dimaklumi dalam demokratisasi keislaman, tetapi lebih kepada perbedaan atau perebutan kekuasaan. Saya setuju berbeda dalam berdemokrasi, tetapi kalau sudah perebutan kekuasaan mungkin sudah tidak bisa berbicara lagi demokratisasi atau fiqih lagi, melainkan siapa yang berkuasa dan punya duit....".

Sementara itu, seorang sumber informasi lainnya ${ }^{14}$ mengemukakan:

'Yang masing-masing pelaku Parpol perjuangkan adalah kepentingan mereka sendiri, bukan perjuangan bagaimana perspektif mereka untuk membangun negara. Kalaupun ada, itu hanya ada pada tingkat retorika, tidak pernah dibumikan dalam dataran relitas. Wacana danperdebatan politik diletakkan hanya menyangkut persoalan kekuasaan. Akibatnnya, beberapa riset menunjukkan masyarakat mulai kehilangan kepercayaan dan apatis terhadap Parpol. Bahkan, akan bersikap sinis terhadap janji-janji demokrasi".

Seorang sumber informasi lainnya ${ }^{15}$, mengemukakan sebagai berikut:

"Sampai saat ini, di Indonesia, belum ada Organisasi Massa (Ormas) Islam yang secara sungguh-sungguh memperhatikan dan memperjuangkan kepentingan umat Islam

\footnotetext{
13 Informan ini adalah Sekretaris Dewan Syari'ah PKS Jawa Barat yang juga Anggota DPRD Jawa Barat hasil Pemilu 2004.

${ }^{14}$ Ia adalah seorang peneliti LIPI, dalam $H U$ Republika, 21 Mei 2005, hIm. 12.

${ }^{15}$ la adalah seorang juru bicara Gerakan Persaudaraan Muslim Indonesia (GPMI), dalam HU Republika, 3 Februari 2005, hlm. 8.
} 
Indonesia. Baik Ormas maupun parpol yang ada, terjebak pada kepentingan sempitnya sendiri. Ini termasuk Ormas besar seperti Nahdlatul Ulama (NU) dan Muhammadiyah, dan partai seperti PPP, PKS, dan PKB".

Seorang akademisi, pengamat politik, dan peneliti $\mathrm{CSIS}^{16}$, mengemukakan:

“... Munculnya ratusan kerumunan (organisasi) manusia yang kemudian menyebut dirinya partai politik, sebagian besar menunjukkan perilaku yang sangat lapar dengan kekuasaan. Ciri umum kerumunan politik tersebut adalah sbb.:pertama, sangat berorientasi kekuasaan. Akibatnya, mereka selalu dirundung konflik internal yang berlarutlarut karena urusan perebutan memperoleh kekuasaan adalah bisnis utama mereka. ... Kedua, kekuatan massa dijadikan andalan utama merebut kedudukan politik. ... Ketiga, membangun oligarki politk ... tujuannya agar semakin berkuasa. Keempat, bersifat feodalis atau sentralis....".

Relevan dengan beberapa pendapat tersebut di atas, data lainnya ${ }^{17}$ menunjukkan bahwa mayoritas responden (61,8 \%) menyatakan kesetujuannya bahwa DPR cenderung memperjuangkan kepentingan kelompoknya daripada kepentingan bangsa. Sedangkan hasil jajak pendapat media tersebut di 13 kota besar, 30 Juli 2000, berkesimpulan lebih dari separuh (53\%) responden merasa tidak puas terhadap upaya DPR dalam memperjuangkan aspirasi rakyat. Selain itu, $71 \%$ menganggap anggota DPR lebih memperjuangkan kelompoknya ketimbang kepentingan rakyat.

Data tersebut memberi gambaran bahwa partai politik lebih berorientasi untuk memperoleh kekuasaan daripada memper-

\footnotetext{
${ }^{16}$ la mengemukakan dalam HU Kompas, 5 Agustus 2005, hlm. 7.

17 Hasil jajak pendapat HU Kompas pada 5 Juli 2000 yang dimuat dalam Kompas, 14 Mei 2001, hlm. 8.
}

hatikan masalah-masalah sosial kemasyarakatan. Artinya, parpol masih mengabaikan fungsi intermediasinya bagi konstituen dan masyarakat umum.

Secara konseptual, Khaldun berpendapat bahwa perubahan yang sifatnya regresif akan terjadi apabila satu kelompok masyarakat lebih berorientasi kekuasaan daripada bertujuan membangun kekuatan solidaritas. Konsep tersebut dapat diinterpretasikan bahwa untuk mencapai perubahan masyarakat ke arah yang diharapkan, perlu memperhatikan kekokohan solidaritas, bukan kekuasaan. Tanpa solidaritas yang kuat dalam berpolitik, progresivitas perubahan akan sulit dicapai. Dengan demikian, orientasi partai-partai Islam sebagaimana diperoleh dari para informan kunci di atas yang menggambarkan bahwa orientasi kekuasaan lebih menonjol daripada orientasi kemasyarakatan, merupakan salah satu kendala yang sangat mendasar bagi pencapaian perubahan sosial partai-partai Islam ke arah yang diharapkan.

Dipandang dari sudut pemikiran Durkheim, tentang teori solidaritas, secara konseptual seharusnya ikatan ideologi dan persamaan kepercayaan partai-partai Islam dapat membentuk dan memperkokoh "solidaritas mekanik" di antara mereka. Namun dalam kenyataannya, godaan kekuasaan menunjukkan lebih tajam daripada memperkokoh "solidaritas mekanik". Demikian juga aspek "solidaritas organik", secara menyeluruh ketergantungan di antara partai-partai Islam untuk membesarkan gerakan kolektivitasnya belum mengarah pada sudut pandang yang sama, terkecuali pencapaian kekuasaan kelompoknya masingmasing. Hal tersebut tanpak juga dari pola pembagian kerja di antara partai-partai Islam belum secara konprehensif berakibat pada terbangunnya konsensus baru dalam memperkokoh tujuanbersama. 
Gunawan Undang, Husni Thamrin; Konflik dan Integrasi Islam Politik

Bertitik tolak dari data empirik dan konsep (teori) tersebut menggambarkan bahwa secara internal konflik terjadi karena berorientasi kekuasaan, fragmatis, dan lemahnya solidaritas. Perebutan kekuasaan merupakan unsur yang mempertajam konflik internal partai politik Islam. Solidaritas objektif (objective solidarity) yang mengacu pada toleransi internal hubungan primordialkeagamaan belum memperkokoh kesatuan sosial kelompok kepartaian. Solidaritas subjektif (subjective solidarity) yang didasarkan pada toleransi eksternal terhadap kelompok luar (out group), justru cenderung lebih dominan dalam membangun pola hubungan kekuasaan melalui koalisi lintas ideologis (crossing ideological coalitions). Partai-partai Islam lebih "tergoda" oleh solidaritas distributif (distributive solidarity) untuk meraih kekuasaan tertentu.

Kedua, secara internal konflik partaipartai Islam disebabkan karena masingmasing partai melakukan ijtihad politik. Seorang informan kunci ${ }^{18}$ mengemukakan kepada peneliti sebagai berikut:

"Syarat-syarat berijthad itu sangat berat, karena yang beritihad itu harus hapal alQuran, fasih berbahasa Arab, menguasai paling tidak lima ribu hadis, dan tidak tercela (bersih). Mengingat persyaratan ijthad yang begitu berat, maka pendirian partai-partai politik Islam cenderung tidak melakukan proses ittihad yang sebenamya; mereka lebih menonjolkan kepetingan individu dan kelompoknya demi kekuasaan. Mereka begitu berambisi mendirikan dan menggiring partai atas nama Islam untuk kepentingan klompoknya; baik partai yang berasaskan Islam maupun partai yang tidak berasaskan Islam. Secara kultural mereka ditopang oleh

\footnotetext{
${ }^{18}$ Is seorang akademisi, Rektor sebuah Universitas Islam, dosen sebuah PTS, dan mantan Kepala SMU Islam di Kota Bandung, simpatisan PKS.
}

masing-masing organisasi massa Islam, seperti Muhammadiyah menopang PAN dan NU menopang PKB. Mereka masing-masing berijthad yang mengakibatkan kebingungan di kalangan umat. Produk ijthad politik mana yang harus diikuti umat.

Berdirinya partai-partai Islam di Indonesia bukan melalui suatu proses iithihad yang betul-betul berdiri di atas kepentingan umat. Mengapa demikian? Dalam konteks politik, kalau ulama benar-benar melakukan iithihad demi kepentingan umat secara universal, sebaiknya melakukan ijtihad kolektif. Bukan ijthad kelompok. Akibatnya, masingmasing kelompok membuat partai baru. Mengapa tidak bersama-sama melakukan iithinad kolektif, misalnya. memperbaiki PPP yang sudah ada sejak Orde Baru. Kan di dalam PPP tersebut sudah ada unsur NU, Muhammadiyah, Persis, bahkan Masyumi. Sebab kalau membuat partai baru kecenderungannya adalah memecah belah umat karena masing-masing merasa benar atas produk ijthadnya tersebut. Yang dirugikan justru masyarakat kelas bawah, sedangkan para elit mempunyai 'imbalan' seperti menjadi anggota legislatif, menteri, dll. ini harus 'dibayar' mahal. Tetapi mengapa NU membuat PKB? Muhammadiyah membuat PAN? Demikian pula PBB yang berbasis massa Persis dan Masyumi.

Apalagi PKS. Berdirinya PKS jauh dapat dianggap sebagai produk ijtihad. Sebab, PKS tidak memiliki ulama sekaliber yang ada di partai Islam lainnya, seperti di lingkungan NU dan Muhammadiyah yang diakui banyak memiliki para mujtahid sebagai syarat berijithad yang benar. PKS ini dirintis oleh orang-orang muda kampus yang tadinya 'golput'. Salah satu organisasi yang menggagasnya adalah Lembaga Dakwah Kampus (LDK) yang berbasis di IPB dan dan Hizbut Tahrir (HT). Kapasitas keilmuan mereka juga masih kurang dibandingkan 
dengan ulama yang ada di NU (PKB) dan Muhammadiyah (PAN). Saya melihat, PKS hanya melakukan 'ijtihad awam' saja yang dilakukan orang per orang yang kemudian menyamakan persepsi dan kekuatan untuk mendirikan wadah partai. Mereka tidak memiliki ulama jumhur. Meskipun ada beberapa, mereka digandeng di tengah jalan sebagai simpatisan; tidak sejak awal. Seperti K. H. Jalaluddin Assyatibi (anggota DPR RI) atau K. H. Saeful Islam (anggota DPRD Jabar), misalnya, ia digandeng di tengah jalan, tidak sejakawal".

Data lainnya dikemukakan seorang ulama yang sangat berpengaruh di Jawa Barat ${ }^{19}$, ia mengemukakan sebagai berikut: "Dari lintasan sejarah, ternyata perbedaan ijtihad politikmerupakan faktor utama perpecahan di kalangan umat Islam. Kalau persoalan perbedaan paham dalam memandang ajaran Islam seperti masalah khilafiyyah (masalah cabang; perbedaan pendapat cara beribadah, seperti qunut, niat, dll. pen.) tidak akan terlalu berpengaruh karena masing-masing pihak sudah mulai menerima adanya perbedaan pendapat, namun kalau sudah menyinggung masalah politik, bisa berakibat serius".

Deskripsi di atas menggambarkan bahwa ijtihad politik yang dilakukan partai-partai Islam masih dilakukan secara parsial. Artinya, hanya dilakukan masing-masing partai politik untuk meligitimasi gerakan kelompoknya yang dibungkus oleh justifikasi isu keagamaan. Mereka cenderung mengabaikan persyaratanpersyaratan ijtihad yang sebenarnya. Hal tersebut mengakibatkan kebingungan di

\footnotetext{
${ }^{19} \mathrm{la}$ adalah seorang ulama berpengaruh di Jawa Barat dan Direktur Pusdai Jawa Barat (sekarang sudah berhenti), dikemukakan dalam HU Pikiran Rakyat, 1 November 2003, hlm. 3.
}

kalangan umat; itihad politik mana yang harus diikuti umat.

Secara konseptual, Khaldun berpendapat bahwa konflik pasti muncul di kalangan orang yang berijtihad tentang masalah agama yang belum jelas. litihad politik yang dilakukan masing-masing partai politik Islam masih bersifat sektoral; tidak universal sehingga tidak dapat dijadikan "payung hukum" bersama oleh kalangan umat Isam di Indonesia. Seorang informan kunci ${ }^{20}$ mengatakan kepada peneliti bahwa ijthad yang dilakukan oleh elit partai Islam adalah termasuk "ijtihad awam", karena tidak dilakukan dan bertujuan untuk kepentingan umat secara universal. Syarat ijthad yang sebenarnya adalah harus hafal al-Quran, fasih berbahasa Arab, menguasai paling tidak lima ribu hadis, dan tidak tercela (bersih).

Sehubungan dengan hal tersebut, walaupun syiyasyah syariyah secara universal tidak terlepas dari perjuangan keagamaan, namun dalam konteks keagamaan dan ketatanegaraan di Indonesia, posisi partai politik Islam, secara internal perlu lebih diperjelas berdasarkan hukum syari'at, termasuk dalam penataan kelembagaannya. Hal ini memerlukan ijtihad kolektif yang melibatkan berbagai mazhab dan kelompok kepartaian untuk dapat dipedomani bersama. litihad politik yang dilakukan masing-masing kelompok, sebagaimana yang terjadi selama ini, dalam sejumlah kasus dapat menimbulkan multi-interpretatif yang menjurus pada suasana konfliktual. Pemikiran politik Khaldun, yakni konflik pasti muncul di kalangan orang yang berijtihad tentang masalah agama yang belum jelas, menjadi relevan dalam penataan sistem dan organisasi kepartaian Islam.

Untuk menata sistem kepartaian di Indonesia, apabila para elit dan politisi Islam belum bisa melakukan ijthad kolektif karena ada hambatan-hambatan multi kultur dan

${ }^{20}$ Lihat footnote 35. 
beragamnya orientasi politik dan kekuasaan, penguasa dapat berijthad. Dalam fiqih siyasah, dalam kemasyarakatan, fiqih menghendaki campur tangan pemerintah dan pemerintah berhak melakukan ijtihad untuk memilih salah satu pendapat yang paling sesuai dengan tuntutan kemaslahatan dan menetapkannya sebagai peraturan perundangan yang dapat mengikat seluruh masyarakat. Hal ini demi menjaga keseragaman amaliah, di samping untuk menghindarkan kesimpangsiuran dan ketidakpastian hukum. Bagi masyarakat, wajib hukumnya menaati yang telah ditetapkan pemerintah tersebut. Fatwa K. H. Ahmad Siddiq terhadap bentuk kenegaraan Republik Indonesia yang berdasarkan Pancasila sudah merupakan bentuk final bagi umat Islam Indonesia, merupakan fakta sejarah bahwa ijtihad fiqih siyasah dapat dilakukan penguasa untuk menjamin kepastian hukum masyarakatnya.

Ketiga, secara internal, konflik mengakibatkan terjadinya fragmentasi kepartaian. Ada beberapa penyebab terfragmentasinya partai-partai Islam yang digambarkan seorang informan kunci ${ }^{21}$ sebagai berikut:

"Di zaman Orde Lama, partai-parati Islam hanya sebatas terpolarisasi, berbeda dengan pasca-Orde Baru yang terfragmentasi. Polarisasi di era Orde Lama terjadi karena saat itu Islam masih dianggap masih belum terlalu penting dalam meraih suatu jabatan. Ketika Islam politik dibendung pada era Orde Baru sehingga terbekap seperti koper, sehingga dengan keterbukaan reformasi, Islam dikemas dan "dibungkus" untuk kepentingan politik pribadi dan kelompoknya sehingga mengakibatkan fragmentasi. Secara spiritual tidak mungkin terjadi fragmentasi,

\footnotetext{
${ }^{21}$ la seorang sejarawan dan budayawan Sunda Jawa Barat, dan ia pun seorang dosen PTS.
}

karena Allah-nya sama, al-Qur'an-nya sama, dan Nabi-nya pun sama, bahkan setelah saya amati, flat form partainya pun sama untuk memperiuangkan Islam, tetapi mengapa mereka tidak bersatu? Karena mereka hanya menggunakan Islam sebagai kendaraan untuk meraih kekuasaan. Karena kendaraan politik lebih gampang dalam meraih kekuasaan. Muaranya bagaimana? Secara politik hingga sekarang mereka tetap tidak berhasil; kepercayaan masyarakat terhadap partai (Islam) bisa terus luntur".

Masalah fragmentasi politik di era pasca-Orde Baru cenderung lebih variatif daripada era Orde Lama. Polarisasi politik pada era Orde Lamamengakibatkan tersekatsekatnya partai ke dalam politik aliran (Islamis, Nasionalis, Komunis), sedangkan pada era pasca-Orde Baru sekat-sekat politik aliran tersebut cenderung lebih kabur. Partai-partai politik Islam pada periode ini lebih terkotakkotak ke dalam lembaga partai politik baru yang lebihelementer.

Kelompok-kelompok polarisasi partai politik pada era-Orde Lama, pada era pascaOrde Baru "membelah diri" menjadi beberapa bagian yang lebih kecil sehingga membentuk "organisme". Dalam Gambar "Polarisasi dan Fragmentasi Partai Politik Islam 1945-2004" telah dijelaskan bahwa "anak kandung" Masyumi pada Pemilu 1999 terfragmentasi ke dalam PBB, PPIIM, PMB, dan PUI bahkan PAN. Hanya PBB dan PAN yang bisa mengikuti Pemilu 2004, yang lainnya terkena electoral treshold. Berdasarkan perolehan suara Pemilu 2004, PBB pun terkena electoral treshold, sehingga pada Pemilu 2009 yang akan datang terancam tidak bisa mengikutinya. Komunitas NU pada Pemilu 1999 terfragmentasi ke dalam PKB, PKU, dan PNU bahkan Partai Suni. PKU, PNU, dan Partai Sunni mengalami electoral treshold sehingga pada Pemilu 2004 bergabung ke dalam PPNUI. Jadi, partai politik berbasis 
massa NUyang mengikuti Pemilu 2004 hanya PKB dan PPNUI. PPP dalam Pemilu 1999 terfragmentasi ke dalam PPP dan PP. PP tidak bisa mengikuti Pemilu 2004 karena terkena electoral treshold. Menjelang Pemilu 2004 terjadi konflik internal di tubuh PPP antara kelompok Hamzah Haz dengan Zainuddin M. Z. sehingga dalam Pemilu 2004 melahirkan sempalan baru di dalam PPP, yakni PBR (semula bernama PPP Reformasi) yang dipimpin Zainuddin M. Z. PBR pun sebenarnya sempalan dari PPP Reformasi. Karena terjadi konflik internal di dalam PPP Reformasi antara kelompok Hamzah Haz dengan kubu Saleh Khalid, maka kubu Zainuddin M.Z. memilih nama PBR, sedangkan kubu Saleh Khalid tetap memilih PPP Reformasi, namun partai PPPReformasi ini tidak lolos verifikasi KPU sehingga tidak bisa mengikuti Pemilu 2004. Demikian pula di dalam komunitas PSII, pada Pemilu 1999 terfragmentasi ke dalam PSII dan PSII 1905. Keduanya masuk kotak electoral treshold sehingga tidak bisa mengikuti Pemilu 2004. Selain parpol-parpol tersebut, menjelang Pemilu 1999 berdiri pula PK, PUMI, PID, PAY, PIB, dan KAMI. Semua partai tersebut terkena elctoral treshold. Terkecuali PK yang saat menjelang Pemilu 2004 berubah menjadi PKS dan memperoleh raihan suara yang cukup signifikan.

Berkaitan dengan fenomena tersebut, secara konseptual Khaldun mengemukakan bahwa politik yang baik menghendaki kekuasaan yang tidak terfragmentasi dan (hendaknya) terpusat pada figur yang berwibawa dan kuat. Namun demikian, secara empirikal, dinamika Islam politik di Indonesia pasca-Orde Baru tidak kontekstual dengan konsep Khalduntersebut.

Fenomena perubahan dari polarisasi ke fragmentasi tersebut ada beberapa indikasi yang perlu dicermati, terutama sebab-sebab dan akibat-akibat dari fragmentasi kepartaian tersebut. Beberapa sebab, di antaranya: 1) terdapat kecenderungan semakin rapuhnya perilaku integratif politik di kalangan partaipartai Islam; agama yang memiliki daya integratif yang tinggi belum menjadi action power di dalam politik; 2) egoisme dan godaan kekuasaan serta fragmatisme politik kekuasaan cenderung semakin mencolok; ibadah ritual belum tercermin di dalam perilaku berpolitik yang cenderung berorientasi kekuasaan; 3) semakin meluntumya politik aliran ideologis keislaman yang berbasis "induk organisasi" kepartaian; 4) lemahnya manajemen konflik partai-partai Islam; dan 5) partai-partai Islam cenderung tidak memiliki arah perjuangan kolektivitas yang jelas dan tegas.

Sementara itu, ada beberapa akibat dari fragmentasi kepartaian ini, di antaranya: 1) semakin melemahnya jalinan solidaritas dalam membangun kekuatan politik sehingga tidak cukup efektif dan efisien terhadap perjuangan kolektivitas kekuasaan; 2) munculnya kembali Islam politik skriptual dari komunitas baru, yakni dari PKS yang dulu pernah diperjuangkan kalangan Masyumi; 3) matinya partai-partai lama, seperti PSII, PSII 1905 dan partai-partai kecil lainnya, seperti PUMI, PID, PIB, PAY, KAMMI); dan 4) munculnya "keterpaksaan" integrasi politik di dalam partaipartai kecil yang terkena alectoral treshold, seperti PKU, PNU, dan Partai Sunni ke dalam PPNUl; sebagai indikasi rapuhnya solidaritas sosial dan berorientasi kekuasaan yang bersifat sesaat dan tidak visibel.

Secara kuantitatif semangat mendirikan partai politik Islam yang didorong oleh semangat keagamaan; dalam wujud visi, misi, dan platform politik yang berorientasi keislaman, cenderung berkembang dengan pesat. Walaupun kemultipartaian tidak hanya pada partai-partai berbasis massa Islam,tetapi kemultipartaian partai-partai berbasis Islam relatif lebih menonjol. Pada Pemilu 1999, 
partai politik berbasis massa Islam yang mengikuti pemilu mencapai 19 OPP. Pada pemilu tersebut, secara akumulatif partai-partai Islam tidak mampu menguasai suara mayoritas. Bahkan, ada beberapa di antaranya yang terkena electoral treshold sehingga terpaksa tidak bisa mengikuti Pemilu 2004, dan ada sebagian di antaranya yang berganti nama atau merger dengan partai lainnya. Demikian pula dalam Pemilu 2004, ada 7 partai-partai yang berbasis massalslam yang mengikuti pemilu tersebut. Lagi-lagi, partai-partai tersebut tidak mampu menguasasi suara mayoritas, sekalipun secara akumulatif. Bahkan di Jawa Barat, raihan suara dan perolehan kursi beberapa partai Islam mengalami penurunan, terkecuali PKS (naik 9,28\%). Namun demikian, secara kualitatif dan ideologis berdirinya partai-partai Islam tersebut belum mencerminkan semangat keagamaan yang sesungguhnya. Ada beberapa alasan, di antaranya, secara empirik, mereka terfragmentatif, hanya berorientasi pada kekuasaan dan bersifat fragmatis yang disertai dengan tingginya intensitas konflik horizontal, sedangkan secara teoritis; sebagaimana dikemukakan Khaldun, tingginya konflik di antara partai-partai tersebut karena lemahnya solidaritas sosial di antara mereka sehingga sangat sulit untuk mewujudkan idealisme semangat keagamaan (Islam) dalam berpolitik. Dengan demikian, secara teoritik tidaklah rasional elit politik Islam mendirikan partai-partai politik yang dilandasi semangat ideologi keislaman apabila solidaritas di antara mereka masih sangat lemah sehingga konflik pun tidak bisa dihindari. Oleh karenanya, mendirikan partai politik yang didasari semangat ideologis keislaman, harus didahului membangun solidaritas sosial, membangun kekuatan integrasi dan harmoni, sehingga semangat keagamaan dalam mendirikan partai politik Islam tidak dibangun "di atas" konflik. Menurut
Khaldun, jika konflik terjadi di kalangan penguasa, maka negara pun akan lemah, cepat hancur, bahkan musnah.

Sebagai akibat lemahnya solidaritas sosial di antara elit politik Islam yang mengakibatkan konflik horizontal, mereka sangat sulit pembangun satu sistem kepartaian yang efektif dan efisien. Terpolanisasi, terfragmentasi, dan beragamnya partai-partai Islam pada pasca-Orde Baru merupakan gejala yang memperkuat lemahnya penataan dan rasionalisasi partai berbasis massa Islam. Pendirian partai-partai yang bersifat sektoral, cenderung lebih mencolok daripada berdasarkan semangat kolegial.

Dari deskripsi di atas dapat dirumuskan bahwa unsur utama yang mendorong konflik partai-partai Islam, di antaranya adalah lemahnya solidaritas sosial, masih berorientasi kekuasaan dan bersifat fragmatis daripada memperjuangkan ideologis kepartaian yang berorientasi kemasyarakatan, dan konflik belum dikelola dengan baik sehingga belum fungsional terhadap progresivitas perubahan sosial. Selain itu, konflik horizontal-internal kepartaian cenderung lebih mencolok daripada konflik vertikal. Sedangkan unsur utama yang mendorong integrasi politik partai-partai Islam cenderung tidak dilatarbelakangi kekuatan solidaritas sosial, melainkan hanya untuk meraih kekuasaan dan fragmatisme serta bersifat sementara (tidak permanen), karena setelah kekuasaan itu mereka raih, integrasi pun melemahkembali.

Keempat, unsur internal berikutnya yang menyebabkan konflik di dalam partaipartai Islam disebabkan karena minimnya tokoh publik sebagai integrator konflik internal. Sejatinya, diperlukan pemimpin kharismatik sebagai perekat solidaritas sosial di antara mereka. Fenomena menunjukkan bahwa pada pasca-Orde Baru tokoh-tokoh perekat 
kesatuan umat, baik dari kalangan intelektual Islam maupun ulama terlibat ke dalam politik kekuasaan, seperti Gus Dur dari NU, Amien Rais dari Muhammadiyah, Kiai "sejuta umat" Zainuddin M.Z. bahkan Cak Nur. Akibatnya, konflik antar-kelompok, tidak ada tokoh kharismatik yang dapat menetralisir dan mengeliminir (integrator dan mediator) masalah-masalah yang dihadapi umat, termasuk di bidang politik. Selain itu. keterlibatan organisasi-organisasi keislaman terhadap politik dan kekuasaan, baik sebagai inisiator (fomal maupun informal) pendiri partai politik (NU pendiri PKB, Muhammadiyah pendiri PAN, dan Persis pendiri PBB) maupun dukungan basis massanya, baik secara langsung maupun tidak langsung, cenderung mempertajam perbedaan-perbedaan pandangan tentang teologis dan furuilyah yang selama ini dihadapi ketiga organisasi keislaman terkemuka di Indonesia tersebut. Demikian juga dukungan NU terhadap PKB, dukungan Muhammadiyah terhadap PAN, dan dukungan Persis terhadap PBB, misalnya, baik secara langsung maupun tidak langsung, walaupun tidak memiliki hubungan organisatoris, tetapi karena secara historis memiliki ikatan sejarah yang relatif kuat (adanya PKB karena adanya NU, adanya PAN karena adanya Muhammadiyah, dan adanya PBB karena adanya Persis) maka mengakibatkan pula fragmentasi di kalangan grass roots. Sikap tegas Ketua Umum PP Muhammadiyah Din Syamsuddin dalam Mukhtamar ke-45, Juli 2005, bahwa Muhammadiyah tidak memiliki hubungan dengan partai politik mana pun, atau sikap NU dalam Mukhtamar ke-31 (2004) di Solo yang kembali ke Khittah dan "netral" terhadap politik termasuk pada PKB, merupakan salahsatu upaya yang sangat positif untuk menjaga kharismatik organisasi keislaman tersebut sehingga berbagai masalah pada tataran grass roots dapat dieliminir sedemikian rupa.
Dengan cara demikian, diharapkan lemahnya solidaritas sosial para elit Islam dalam membangun dan menentukan arah kebijakan yang bersifat kolektivitas di bidang politik dan kekuasaan dapat ditingkatkan seoptimal mungkin.

Berkaitan dengan keterlibatan kalangan elit Islam ke dalam politik kekuasaan, salah seorang tokoh $\mathrm{NU}^{22}$, mengemukakan: "... Saat sekarang Indonesia membutuhkan figur yang bisa menjadi sosok yang dianalogikannya dengan "pemain bola", yaitu memiliki teknik atau skill, fisik yang prima, mampu bekerja sama yang baik, cerdas, dan tidak mudah disogok (disuap)...."

Secara internal, partai politik Islam memerlukan tokoh sentral sebagai pemersatu umat Islam. Seorang informan kunci ${ }^{23}$ mengemukanan sebagai berikut:

"... Umat Islam selama ini tidak memiliki tokoh sentral yang kharismatik dan bisa menyatukan semua lapisan umat Islam. Amien Rais sudah kental dengan kemuhamadiyahan dan PANnya, Gus Dur sudah kental dengan ke-NU-an dan PKB-nya, demikian pula Yusris Ihza Mahendra sudah sangat kental dengan Persis dan PBB-nya. Dalam kepemimpinan politik, hal tersebut semakin parah karena kultur di Indonesia tidak memandang program, melainkan tokoh. SBY, Megawati, dan Gus Dur bisa naik menjadi pemimpin (presiden, pen.), karena ketokohannya, bukan karena kemampuan programnya untuk bisa membangun bangsa ini. SBY bisa naik jadi presiden meskipun hanya didorong oleh partai kecil (Partai Demokrat, pen.) karena ketokohannya. Hanya sayang, dari sekian banyak tokoh di Indonesia, terutama Islam,

\footnotetext{
${ }^{22}$ la salah seorang tokoh yang berpengaruh di NU, dalam HU Pikiran Rakyat, 14 Februari 2005, hIm. 6.

${ }^{23}$ la seorang desainer grafis dan multi media pada sebuah agen iklan, pernah bekerja di penerbit, dan aktivis Persis.
} 
Gunawan Undang, Husni Thamrin; Konflik dan Integrasi Islam Politik

tidak ada seorang pun yang bisa tampil menyatukannya. Kita hanya berharap kepada tokoh khayalan dari ramalan Jayabaya, yakni Satria Piningit. ..."

Merespon perpecahan PKB kubu Gus Dur/Muhaimin Iskandar dengan kubu Alwi Shihab/Syaifullah Yusuf pasca-Mukhtamar II PKB, seorang wartawan senior ${ }^{24}$ mengemukakan:

“... Perpecahan yang melanda PKB yang melibatkan pentolan-pentolan $\mathrm{NU}$ - termasuk Gus Dur - ikut pula menambah gumpalan tanda tanya penuh ketidakmengertian. Walau tidak semua warga NU akar rumput mendukung $P K B$, namun dampak perpecahan partai yang dibentuk oleh PB NU tahun 1998 itu, cukup membuat miris sebagian besar warga NU. ...."

Minimnya figur publik sebagai integrator pemersatu umat Islam dikemukakan seorang informan kunci ${ }^{25}$ berikut ini:

“... Suatu kelemahan dalam struktur Islam; katakanlah dibandingkan dengan Nasrani (Nashoro), misalnya, belum mampu melanggengkan figur kepemimpinan dan memiliki dogma yang kuat terhadap umatnya. Dalam Nasrani, ketika George Bush Yunior (George Walker Bush) ingin jadi Presiden Amerika Serikat, misalnya, yang pertama kali ia mintai restunya adalah kalangan Patikan. Setelah ia mendapat restu dari Patikan, barulah ia melaksanakan debut kepemimpinan menjadi calon Presiden Amerika Serikat. ... Kalau Islam di Indonesia memiliki imamah (pemimpin) yang kuat dan dapat diterima oleh semua lapisan, mungkin tidak akan rentan konflik sehingga benar-benar bisa menjadi

\footnotetext{
${ }^{24}$ Selain sebagai seorang wartawan senior, ia juga penasehat Lajnah Talif wa Nashr PW NU Jabar, dalam HU Pikiran Rakyat, 12 Agustus 2005, hlm. 20.

${ }^{25}$ Informan ini adalah seorang aktivis LSM (Lembaga Swadaya Masyarakat) dan pengusaha, juga sering mengunjungi beberapa pesantren besar di Indonesia.
}

rahmatan lil 'alamin. Namun, dengan bermunculannya figur-figur kecil dalam suatu kelompok yang menganggap dirinya imam dan berpikiran jangka pendek, maka hal tersebut akan memperlemah terhadap struktur Islam. ...Karena tidak ada figur pemimpin, umat akan bercerai berai dalam pandangannya masing-masing. ... Mampukah ke depan Islam memiliki figur sebagai 'kiblat' semua golongan? Ini sangat penting untuk kebangkitan Islam ke depan, termasuk dalam bidang politik. ... Islam dipandang sebagai syari'at hidup dan Islam dipandang sebagai gerakan politik, memang akan seperti sekarang ini karena mereka menentukan imamsekehendak kelompoknya masing-masing. Dari kelompok Muhammadiyah, misalnya, tidak akan bisa mengakui kepemimpinan dari golongan Nahdliyin, demikian pula sebaliknya. Hal ini terjadi karena tidak figur ada pemersatu. ... Pada era Hasyim Ashari atau M. Natsir, meskipun terjadi klik di antara mereka, mereka masih bisa duduk bersama dan berpikir rasional. Saat itu mereka berpikir untuk kepentingan bersama, sedangkan saat sekarang hanya berpikir untuk kepentingan kelompoknya, merekatidak mampu meleburkan diri untuk kepentingan negara. Di era sekarang, kultur duduk bersama dan berpikir rasional dalam berpolitik tersebut sudah tidak ada. ...Untuk meghindari konflik dan meningkatkan integrasi, selain diperlukan kekuatan solidaritas sosial, menurut Khladun, politik yang baik menghendaki terpusat pada figur yang berwibawa dan kuat. Masalah ini pun merupakan salah satu kelemahan yang dihadapi partai-partai Islam, khususnya pada periode pasca-Orde Baru. ..."

Nara sumber lainnya ${ }^{26}$ menegaskan bahwa umat Islam agar bisa bangkit dengan

\footnotetext{
26 Ia Pengasuh Pondok Pesantren Candang Pinggan, Kertasmaya, Indramayu, dalam HU Pikiran Rakyat, 14 Februari 2005, hlm. 6.
} 
"kecerdasan kolektif'. Artinya, kalangan umat Islam bisa menggalang kekuatan untuk bisa menghasilkan sesuatu yang lebih bermakna bagi bangsa ini, dan jangan sampai terjebak dengan sikap egosentris golongan.

Pandangan beberapa informan kunci di atas agar umat Islam memiliki figur sentral kepemimpinan sebagai pemersatu politik dan keagamaan, meskipun secara empirikal relatif tidak kontekstual dengan kultur politik dan keagamaan yang berkembang di Indonesia yang menganut multi kultural, yakni kultur politik Sunni dan Syi'ah (Syiii), namun secara konseptual (fiqiyah) bisa dilaksanakan. Mazhab Sunni dan Syi'ah sama-sama bersumber dari mazhab Mu'tazilah. Sebagai mayoritas di Indonesia, mazhab Sunni terbagi ke dalam beberapa golongan, di antaranya NU, Muhammadiyah, dan Persis yang secara umum bersumber dari mazhab Hanafi, Maliki, Syafi'i, dan Hanbali. Sedangkan mazhab Syiah di Indonesia belum begitu berkembang.

Secara historis, kultur politik yang ingin dibangung founding fathers Islam politik di Indonesia adalah kultur politik Sunni yang tidak mengenal "tokoh sentral" sebagaimana kultur politik Syi'ah. Kaum Sunni berpendapat bahwa masalah imamah (kepemimpinan) merupakan persoalan keduniaan yang penanganan dan pembentukannya diserahkan kepada umat untuk dimusyawarahkan. Secara teologis musyawarah merupakan konsekuensi logis dari sikap tauhid (monoteisme). Bidang ijtihad memerlukan musyawarah. Orang yang berhak melakukan musyawarah untuk kepentingan umum adalah Majelis Syura. Sementara itu, kalangan Syi'ah berpendirian bahwa imamah adalah masalah sentral dan bagian dari rukun iman dan kepala pemerintahan bukanlah hak setiap orang, melainkan hak Ali bin Abi Thalib dan anak keturunannya dengan sistem penunjukan. Persoalan imamah termasuk salah satu rukun agama, sedangkan dalam tradisi Sunni hanya merupakan masalah furuk (hukum tambahan) dan dalam Sunni istilah ini lebih populer dengan sebutan khilafah. Persoalan khilafah dalam Sunni lebih dikaitkan pada persoalan kepemimpinan politik daripada sebagai persoalan keagamaan. Paradigma pemikiran politik Sunni menekankan permufakatan (ijma') dan pembaiatan (bay'ah) dalam proses pemilihan kepemimpinan. Dengan demikian, mengingat mayoritas golongan yang berkembang di Indonesia adalah mazhab Sunni, dan hal tersebut berpengaruh besar terhadap faksi-faksi politik yang berkembang dan terfragmentasi di Indonesia, maka untuk menentukan kultur kepemimpinan politik memerlukan ijtihad yang melibatkan Majelis Syuro dari berbagai golongan kaum Sunni Indonesia hingga tercapainya permufakatan (ijma) tentang figur sentral yang memiliki otoritas dan mengikat bagi semua golongan dalam struktur politik Islam Indonesia. Mengingat masalah imamah (kepemimpinan) dalam Sunni merupakan persoalan keduniaan yang penanganan dan pembentukannya diserahkan kepada umat untuk dimusyawarahkan, dan dalam musyawarah tidak tercapai kemufakatan di antara perwakilan Majelis Syuro, maka dapat diserahkan kepada penguasa negara (pemerintah). Secara fiqiyah, hal ini sangat memungkinkan, sebab fiqih menghendaki campur tangan pemerintah dan pemerintah berhak melakukan ijtihad untuk memilih salah satu pendapat yang paling sesuai dengan tuntutan kemaslahatan dan menetapkannya sebagai peraturan perundangan yang 
Gunawan Undang, Husni Thamrin; Konflik dan Integrasi Islam Politik

dapat mengikat seluruh masyarakat (Islam).

Bertitik tolak dari hal tersebut, secara konseptual Khaldun berpandangan bahwa untuk menghindari konflik, menurut Khaldun, cukuplah setiap orang mengetahui bahwa kezaliman diharamkan atasnya berdasarkan hukum akal. Khaldun memandang, dugaan para ilmuwan lainnya yang menganggap bahwa pertentangan (konflik) hanya mungkin ada dengan adanya syari'at di satu sisi, dan kedudukan imam di lain sisi, tidaklah benar. Pertentangan itu dapat dilenyapkan, baik dengan adanya kekuatan para pemimpin atau dengan usaha rakyat menjauhkan diri dari pertikaian dan saling berlaku zalim, maupun dengan adanya jabatan imam tersebut. Dengan demikian, dalil aqli (akal) yang didasarkan kepada premis itu tidak tahan uji. Maka dengan itu teranglah keharusan adanya imam diindikasikan oleh syari'at melalui konsensus atau ijma" (Khaldun, 2000: 236).

Bertitik tolak dari konsep Khaldun tersebut, manajemen konflik partai-partai Islam hendaknya bersandar pada hukum akal (aqli) berdasarkan hasil konsensus atau ijma' para pemimpin (imam) politik berdasarkan hukum syar'at (Al-Qur'an dan Al-Hadits). Dalam hal ini, elit Islam dituntut untuk membuat konsensus baru dalam upaya penataan organisasi kepartaian dan manajemen konflik yang lebih visioner berdasarkan ijma.

\section{Unsur-unsur Internal Penyebab Integrasi}

Pertama, unsur kekuasaan. Dari beberapa pengamatan langsung di lapangan menunjukkan bahwa integrasi politik yang dilakukan elit partai Islam bukan berdasarkan pada kekuatan solidaritas kelompok keislaman secara mumi, tetapi hanya bersifat politis dan kekuasaan serta tidak bersifat permanen. Integrasi politik yang dilakukan Poros Tengah untuk mendukung Gus Dur sebagai presiden dalam Sidang Umum MPR pada Oktober
1999; misalnya, hanya bersifat sesaat. Integrasi di antara mereka kemudian buyar oleh peristiwa Sidang Istimewa MPR pada Juli 2001 dimana posisi Gus Dur jatuh dari kursi presiden yang kemudian digantikan oleh Wapres MegawatiSoekarnoputeri.

Seorang informan kunci ${ }^{27}$, mengemukakan kepada penulis sebagai berikut:

"... Solidaritas di antara mereka hanya ada ketika mereka belum meraih kekuasaan atau mereka masih miskin. Tetapi kalau mereka sudah meraih kekuasaan dan telah memiliki uang dan posisi kekuasaan, solidaritas di antara mereka luntur. Artinya, solidaritas di antara mereka hanya bersifat politis dan fragmatis. ... Saya melihat para politisi di Indonesia itu sangat fragmatis dan tidak ideologis. Hanya sedikit yang ideologis, misalnya ada beberapa orang di PKS. Tetapi Anda lihat sendiri, di dalam PKS sendiri mulai muncul problem-problem yang berkaitan dengan uang, penyalahguaan kekuasaan, dsb. ... Menurut pendapat saya, koalisinya partai-partai Islam dengan non-Islam (nasionalis sekuler, dII.) itu bukan melunturnya politik aliran atau melunturnya ideologi partai, tetapi itu cuma koalisi fragmatis atau koalisi yang bersifat strategis saja. Lagi-lagi intinya untuk mendapatkan kekuasaan atau bagi-bagi kekuasaan, bukan untuk memperjuangkan ideologi partai. ...".

Karena latar belakang integrasi hanya bersifat politis dan kekuasaan bahkan fragmatis, maka terdapat fenomena perubahan sosial dalam proses integrasi (koalisi) politik antara

\footnotetext{
${ }^{27}$ la seorang akademisi dan Ahli Peneliti Utama dan Kepala Pusat Penelitian Politik, Lembaga IImu Pengetahuan (LIPI), Jakarta.
} 
partai-partai Islam dengan partai-partai nasionalis-demokratis. Pada era Orde Lama, idealisme keislaman (ideologi kepartaian) relatif menonjol. Mereka cenderung sulit melakukan integrasi politik dengan partai-partai berasas nasionalis, apalagi komunis. M. Natsir; misalnya, cenderung tidak kompromistis terhadap ide-ide Soekarno yang nasionalis. Namun, pada pasca-Orde Baru integrasi politik antara partai berbasis Islam dengan partai yang berbasis nasionalis-demokratis, justru cenderung lebih menonjol daripada integrasi antar-partai Islam.

Poros Tengah yang "dinahkodai" Amien Rais yang berintegrasi dengan PDIP dalam Sidang Istimewa MPR pada bulan Juli 2001, merupakan fakta sejarah yang mendukung terhadap peristiwa terintegrasinya Islamisnasionalis. Berpasangannya Hamzah $\mathrm{Haz}$ (PPP) dengan Megawati (PDIP) dalam pemilihan presiden 2004 adalah fakta lain yang mendukung terhadap terjadinya pergeseran integrasi partai berbasis Islam dengan partai berbasis demokratis-nasionalis. Demikian pula dukungan PKS terhadap SBY (Partai Demokrat) dalam putaran kedua Pilpres/Wapres 2004. Sejak putaran pertama, agaknya PKS tidak secara terbuka mendukung pasangan Amien Rais-Siswono Yudhohusodo yang sama-sama berbasiskan Islam. Bahkan, PBB sejak awal pencalonan, secara tegas lebih mendukung SBY daripada calon presiden Amien Rais, padahal Yusril Ihza Mahendra dan Amien Rais sama-sama dari generasi M. Natsir.

Fenomena tersebut tidak hanya terjadi pada tingkat pengurus pusat, tetapi di tingkat pengurus daerah pun terjadi integrasi politik yang lebih bervariasi dan tidak "sebangun" dengan yang terjadi di tingkat pusat. Dalam Pilkada Kabupaten Bandung (Oktober 2005); misalnya, Koalisi Poros Umat (KPU) yang semula dibangun partaipartai Islam (PKS, PPP, PKB, PAN, dan PBB), ditandai oleh peristiwa keluarnya PKB dari KPU dan berintegrasi dengan Koalisi Karya Perjuangan Bangsa (KKPB), yang terdiri atas Partai Golkar, PDIP, dan PKB sendiri. KKPB yang mengusung pasangan Obar Sobarna/PG-Yadi Srimulyadi/PDIP, menang tipis (kurang dari $2 \%$ ) dari pasangan Dudin-Ridho yang diusung KPU. Demikian pula dalam Pilkada di daerah lain, integrasi politik tersebut berbeda-beda: di Kota Depok terjadi integrasi PKB, PG, PPP, PDIP, PDS, PAN, PBB, PBR, PKPI, dan PKPB; di Kabupaten Sukabumi integrasi antara PKS, PKPB, PAN, dan PKB, sementara di Kabupaten Pandeglang, PPP, PDIP, dan PKS bisa berintegrasi memenangkan pasangan Ahmad Dimyati-Erwan Kurtubi sebagai Bupati Pandeglang periode 2005-2010, sedangkan PAN, PBB, dan PBR membangun koalisi tersendiri dan mengusung calon yang berbeda.

Seperti halnya di tingkat pusat, integrasi politik di tingkat daerah pun (Jawa Barat) menggambarkan bahwa faktor pendorong integrasi politik cenderung lebih mengejar kepentingan kekuasaan daripada membangun semangat keagamaan dan solidaritas sosial antar-partai Islam. Dengan demikian, terintegrasinya partai-partai Islam dengan partai yang berbasis nasionalis-demokratis menggambarkan pudarnya ideologis politik pada pasca- 

Orde Baru. Seorang informan kunci ${ }^{28}$ menanggapi fenomena tersebut dari sudut pandang kekuasaan:

"... Bedakan integrasi dengan konvergensi. Koalisi lebih bersifat pragmatis. PKS bisa berkonvergensi dengan Partai Golkar, yang penting menang. Itu lebih kepada percobaanpercobaan laboratorium politik. Yang dimaksud dengan konvergen tidak mesti secara kelembagaan PDIP dan PKS menyatu, tetapi kalau hatinya sudah menyatu, bikin program apa pun di DPR bisa bersatu. Jadi, sekat partai tidak usah dipermasalahkan. Konvergensi dalam pengertian yang lebih universal, bukan pengertian fragmatis yang dikatakan Anda (pewawancara/peneliti) integrasi koalisi. Jadi, dua hal ini sedang terjadi sekarang ini. Koalisinya PKS dengan partai-partai Islam yang pluralis".

Pimpinan PKS lainnya ${ }^{29}$ mengemukakan sebagai berikut:

"Untuk memelihara dan menjaga pluralisme bangsa ini, kami mengembangkan pluralisme tersebut melalui Pilkada. Ada 48 koalisi Pilkada dengan aneka ragam partai politik. Dari 48 Pilkada itu, 40 Pilkada kami menangkan dengan rekan-rekan koalisi kami. Bahkan di Indonesia bagian Timur, PKS juga berkoalisi dengan PDS, yaitu partai yang unsurnya adalah mayoritas umat Kristen. Jadi, PKS bukan hanya berteori saja dalam melaksanakan pluralisme, tetapi juga dalam praktik."

\footnotetext{
${ }^{28}$ la adalah Sekretaris Dewan Syari'ah PKS Jawa Barat yang juga Anggota DPRD Jawa Barat hasil Pemilu 2004.

${ }^{29}$ la adalah salah seorang Dewan Syari'ah DPP PKS, mengemukakan saat penutupan Munas I PKS di Jakarta, dalam HU Kompas, 1 Agustus 2005, hlm. 4.
}

Terminologi apapun (integrasi ataupun koalisi atau konvergensi) yang digunakan dalam proses politik seperti digambarkan dalam Pilkada di atas, tetap saja bermuara pada percobaan kekuasaan yang bersifat politis-fragmatis. Tujuannya tetap sama, yakni untuk melanggengkan kekuasaan: mereka cenderung mengabaikan semangat kolektivitas ideologi kepartaian (Islam) yang seharusnya dijadikan acuan bersama dalam memenangkan kekuasaan.

Fenomena tersebut menunjukkan bahwa faktor perebutan kekuasaan merupakan unsur yang menghambat integrasi partai Islam. Unsur solidaritas objektif (objective solidarity) yang mengacu pada ikatan primordial-keagamaan sebagai satu kesatuan ideologis belum menjadi acuan dalam membangun pola hubungan internal partai Islam. "Integrasi objektif' sebagaimana terjadi dalam kelompok "Poros Tengah" yang semula pendukung utama Gus Dur, tiba-tiba berubah haluan melakukan solidaritas subjektif (subjective solidarity) dengan PDIP dan Partai Golkar pada Sidang Istimewa MPR Juli 2001 untuk meng-impeachment Gus Dur dari kursi kepresidenan yang kemudian digantikan oleh Megawati Soekarnoputeri. Peristiwa tersebut menggambarkan bahwa "solidaritas subjektif" lebih menonjol daripada "solidaritas objektif" karena dilatarbelakangi oleh solidaritas distributif (distributive solidarity) dalam pembagian (distribusi) kekuasaan. Dengan demikian, secara organisatoris "Poros Tengah" hanya dijadikan alat sebagai "solidaritas distributif" dalam pembagian kekuasaan dan tidak dijadikan "rintisan awal" untuk melakukan integrasi secara permanen yang terikat oleh "solidaritas objektif".

Kedua, integrasi bersifat sesaat. Integrasi antar-partai Islam sifatnya hanya sesaat. Dan, itu pun hanya untuk kepentingan lobi-lobi politik internal maupun eksternal partai yang berorientasi kepentingan pribadi atau 
kelompok. Dengan demikian, integrasi yang bersifat sementara (temporary integration) tersebut menunjukkan masih lemahnya "solidaritas objektif" di antara merekasehingga secara politis belum berdampak positif bagi perbaikan partai politik. Artinya, integrasi yang mereka lakukan masih disfungsional terhadap perubahan dalam proses pencapaian tujuan kolektivitas partai-partailslam.

Menanggapi intensitas konflik dan integrasi, informan kunci ${ }^{30}$, mengemukakan:

“... Bahkan, menurut pendapat saya perpecahan di dalam partai-partai politik Islam lebih kental lagi daripada periode sebelumnya. Anda lihat saja yang beraliran tradisionalis ataupun yang modermis. Di NU misalnya, ada $P K B, P K U, P N U$ bahkan PBR, walaupun ada di antaranya orang yang modernis. ... Saya ingin mengatakan; seperti juga yang selalu saya katakan dan yang saya dapatkan pelajaran sejak mahasiswa dulu, pertama, yang namanya partai-partai Islam itu cuma memiliki potential power, bukan actual power. Kemajemukan partai-partai Islam; termasuk kemajemukan di dalam internal masingmasing partai; kemajemukan mazhab; seperti Syafii, Hambali, dll., ataupun munculnya Islam modernis, Islam tradisionalis, Islam liberal, dll. menyebabkan sulit untuk disatukan menjadi sebuah fenomena kekuatan politk. Kedua, egoisme para pemimpin Islam juga menyebabkan sangat sulitnya merger politik dalam pengertian power ataupun merger dalam pengertian penyatuan partai-partai politik yang tunggal atau yang tidak terlalu banyak (rasionalisasikepartaian)....".

Dari kasus yang diteliti, konflik internal partai cenderung lebih mencolok daripada konflik antar-partai Islam. PPP dilanda konflik internal sehingga

\footnotetext{
${ }^{30}$ la seorang akademisi dan Ahli Peneliti Utama dan Kepala Pusat Penelitian Politik, Lembaga Ilmu Pengetahuan (LIPI), Jakarta.
}

menjelang Pemilu 2004 terbentuk PBR, dan pasca-Pemilu 2004, PPP pun dilanda perpecahan dan pemecatan kepengurusan karena terjadi kontroversi masalah Silatnas, khususnya antara kubu Hamzah $\mathrm{Haz}$ dengan kubu Suryadharma Ali. Dalam Mukhtamar Islah PBR di Bali, tampaknya belum mencerminkan semangat islah. Insiden pemukulan dan penusukan antar-anggota malah mewarnai forum tertinggi partai itu. ${ }^{31}$ Mukhtamar Islah PBR ditandai pengeroyokan terhadap kader PBR hingga menderita luka tusuk. ${ }^{32}$ Mukhtamar pun ditandai keluarnya sejumlah pimpinan teras dari kepengurusan PBR, termasuk Zainuddin M. Z., setelah dalam forum tertinggi tersebut Ketua Umum DPP PBR Periode 2006-2011 digantikan Bursah Zarnubi.

Sebelum Munas II (2005), PAN juga dilanda konflik internal, khususnya gugatan dari kalangan muda yang mengancam akan membuat partai baru (tandingan), khususnya dari generasi muda Muhammadiyah, karena PAN dianggap tidak mampu memperjuangkan warga Muhammadiyah dan konstituen PAN secara optimal. Intensitas konflik internal yang cukup menonjol adalah di PKB. Kepengurusan "kembar" pascaMukhtamar II (2005) terjadi akibat saling klaim antara kubu Gus Dur/Muhaimin Iskandar denngan kubu Alwi Shihab/ Syaefullah Yusuf. Situasi tersebut berpengaruh terhadap perpecahan kepengurusan di daerah, seperti di DIY dan Jawa Timur. Berlarut-larutnya konflik internal tersebut mengakibatkan keterlibatan kiai khos di lingkungan NU. Munas Alim Ulama NU dan Mukernas PKB kubu Alwi Shihab yang

\footnotetext{
${ }^{31}$ HU Kompas, 24 April 2006, hlm. 2.

${ }^{32} \mathrm{HU}$ Republika, 24 April 2006, hlm. 3.
} 
diselenggarakan 28 dan 29 Mei 2005, belum mampu menjadi sarana ishlah di antara mereka. Bahkan, konflik internal di PKB tersebut mengakibatkan konflik horizontal dalam bentuk bentrok fisik antar-pendukung di arena Munas Alim Ulama dan Mukernas PKB. Karena konflik tersebut tidak dapat mereka selesaikan secara internal partai, akhirnya ditempuhlah jalur hukum formal (litigasi) yang dimenangkan PKB kubu Gus Dur/Muhaimin Iskandar di Pengadilan Jakarta Selatan. Keputusan aparat hukum pun ternyata tidak menyelesaikan masalah internal PKB, sebab pada $1-2$ Oktober 2005 di Surabaya, PKB versi Alwi Shihab/Saefullah

Yusuf menyelenggarakan pula Munas II PKB yang didukung oleh sejumlah kiai berpengaruh di lingkungan NU, seperti $\mathrm{K}$. H. Abdullah Fagih, K. H. Idris Marzuki, K. H. Masduki Mahfud, K. H. Sholeh Qosim, K. H. Nurul Djazuli, K. H. Idris Marzuki, K. H. Mas Subadar, K. H. Warsun Munawar, K. H. Dimyati Rais, K. H. Muhaiminan Gunardo, K. H. Chasbullah Badawi, K. H. Abdurrahman Chudlori, K. H. Sofyan, dan K. H. Anwar Iskandar. Dalam Mukhtamar II PKB versi kelompok Alwi Shihab/ Saefullah Yusuf tersebut, terpilih Choirul Anam (Cak Anam) sebagai Ketua Dewan Tanfidz PKB periode 2005-2010 menggantikan Alwi Shihab, dan K. H. Abdurrahman Chudlori (Mbah Dur) sebagai Ketua Dewan Syuro PKB menggantikan Gur Dur. Kehadiran para kiai sepuh dalam Mukhtamar tersebut; seperti K. H. Abdullah Faqih, mengisyaratkan bahwa PKB yang "diakui" kiai NU adalah PKB Alwi Shihab.

Memasuki bulan November 2005, majelis kasasi Mahkamah Agung membatalkan keputusan Pengadilan Negeri Jakarta Selatan dan menganggap tidak sah atas pemecatan Alwi Shihab dari jabatan Ketua Umum DPP PKB. Tetapi PKB kubu Gus Dur/Muhaimin Iskandar menganggap putusan kasasi Mahkamah Agung tidak berpengaruh terhadap hasil Mukhtamar II versi mereka diSemarang.

Meskipun telah ditetapkan putusan kasasi Mahkamah Agung, sampai dengan bulan April 2006 konflik internal yang melanda PKB pasca-Mukhtamar II belum ada jalan pemecahannya dan masih terbentuk kepengurusan "kembar" pada partai "anak kandung" NU tersebut, yakni pengurus PKB versi Gus DurMuhaimin Iskandar (Ketua Dewan Syuro dipegang Gus Dur dan Ketua Umum Dewan Tanfidz dipegang Muhaimin Iskandar), dan PKB versi Alwi Shihab/ Saefullah Yusuf (Abdurrahman Chudlori atau Mbah Dur terpilih sebagai Ketua Dewan Syuro menggantikan Gus Dur dan Choirul Anam atau Cak Anam terpilih sebagai Ketua Umum Dewan Tanfidz menggantikan Alwi Shihab).

Sedangkan PKS dan PBB relatif kondusif saat menjelang dan pasca-Munas atau Mukhtamar. Artinya, konflik dua partai ini cenderung tertutup; tidak terbuka seperti partai yang telah dibahas di atas.

Ada beberapa sebab lemahnya integrasi di dalam partai-partai Islam, di antaranya lemahnya semangat keagamaan dalam membangun solidarytas kelompok atau "solidaritas objektif", terlalu menonjolnya kepentingan politik dan kekuasaan, lemahnya idealisme semangat kolektivitas (in group idealism), beragamnya ijtihad politik, berkembangnya fragmentasi, dan minimnya pemimpin kharismatik yang mampu mengintegrasikan (unifikasi) partai-partai Islam secara rasional.

Ketiga, rasionalisasi kepartaian masih sulit dilakukan. Rasionalisasi partai-partai Islam merupakan upaya kolektivitas untuk melakukan pendekatan integrasi (unifikasi) 
kelembagaan kepartaian. Berdasarkan pertimbangan historis, paling tidak ada dua peristiwa yang perlu dicermati, yakni, (1) kegagalan kesepakatan Kongres Umat Islam pertama di Yogyakarta, Juni 1945 untuk menjadikan Masyumi sebagai satu-satunya partai umat Islam yang kemudian "dinodai" oleh berdirinya NU, PSII, Perti, dll. Akibatnya, saat menjelang Pemilu 1955, partai Islam terpolarisasi dan tidak mampu memposisikan dirinya sebagai pemenang, apalagi menguasai mayoritas tunggal kekuasaan, meskipun mayoritas masyarakat Indonesia beragama Islam, dan (2) kebijakan pemerintahan Orde Baru melakukan fusi partai politik menjelang Pemilu 1977. Partaipartai Islam (NU, PSII, Parmusi, dan Perti) yang difusikan ke dalam PPP tidak bisa berkembang optimal. Salahsatu penyebabnya adalah otoritariannya pemerintahan Orde Baru ketika itu, selain PPP pun menjadi "kubangan" konflik yangberkepanjangan.

Dari penelitian sebelumnya, upaya unifikasi atau rasionalisasi kepartaian Islam tersebut tidak berpengaruh efektif terhadap perubahan sosial politik umat Islam. Dari tujuh kali Pemilu selama Orde Lama dan Orde Baru (1955, 1971, 1977, 1982, 1987, 1992, dan 1997), tidak satu pun partai Islam pernah menang secara signifikan dalam Pemilu, bahkan perolehan suara akumulatifnya pun belum pernah menguasai suara mayoritas.

Unifikasi partai-partai Islam semakin sulit dilakukan pasca-kejatuhan Presiden Soeharto 21 Mei 1998. Menjelang Pemilu 1999, dari 48 OPP, partai-partai Islam semakin terfragmentasi ke dalam sekitar 19 partai Islam. Demikian pula saat menjelang Pemilu 2004, dari 24 OPP, terdapat sekitar 7 partai Islam. Bahkan, yang sudah terkena electoral treshold pun berganti "baju"; tidak melakukan unifikasi ke partai Islam lainnya, termasuk PK (menjelang Pemilu 2004 berubah nama menjadi PKS), PPNU (menjelang Pemilu 2004 berubah nama menjadi PPNUI). Malah, di internal PPP terbentuk sempalan partai baru, yakni PBR (partai baru Pemilu 2004, pada Pemilu 1999 belum terbentuk) sebagai buntut konflik kubu Hamzah Haz dengan kubu Zainuddin M.Z. di dalam PPP, bahkan PPP Reformasi meskipun tidak bisa mengikuti Pemilu 2004. Artinya, ketika muncul suatu harapan terbentuknya unifikasi dan rasionalisasi kepartaian dalam partai-partai Islam, yang terjadi justru terbentuknya sempalansempalan partai baru yang lebih terfragmentatif.

Upaya unifikasi partai-partai Islam sulit dilakukan karena pada umumnya mereka hanya berorientasi kekuasaan dan lemahnya solidaritas sosial di antara mereka. Seorang informan kunci ${ }^{33}$, menggambarkan sebagai berikut:

"... Kalau menurut pendapat saya yangterjadi selalu terpecahnya partai-partai itu; seperti yang terjadi di partai-partai di luar Islam. Dulu sebelum pemilu 1955 yang ada hanya Partai Masyumi. Tetapi menjelang Pemilu 1955, karena NU merasa dipecundangi oleh Masyumi; misalnya, maka kemudian mereka mendirikan partai sendiri sehingga berdirilah Partai NU. Demikian pula partai-partai berbasis Islam lainnya, karena di antara mereka masing-masing merasa dijahili sehingga tidak menjadi kekuatan yang tunggal. Ini terjadi karena godaan-godaan kekuasaan. Yang jelas menurut pendapat saya, godaan untuk meraih kekuasaan dan uang itu yang menyebabkan sulitnya menyatukan partai-partai politik untuk menjadi satu kekuatan besar. Dan godaan kekuasaan itu yang menyebabkan sangat sulitnya partaipartai politik itu di tingkat internal; termasuk di partai-partai Islam, untuk bisa mengelola konflik internal mereka, dan ini kalau terus-

\footnotetext{
${ }^{33}$ Ia seorang akademisi dan Ahli Peneliti Utama dan Kepala Pusat Penelitian Politik, Lembaga IImu Pengetahuan (LIPI), Jakarta.
} 
terusan terjadi bisa berbahaya bagi masa depan demokrasi di Indonesia....".

Dari gambaran umum di atas, dapat diambil kesimpulan sementara bahwa berdasarkan data dari lapangan, relatif sangat sulit dilakukan upaya-upaya unifikasi atau rasionalisasi kepartaian Islam. Hal tersebut sangat dipengaruhi beberapa faktor, di antaranya semangat keagamaan yang memiliki potensi sebagai perekat dan daya integratif tinggi, masih belum terimplementasi secara efektif dalam membangun solidaritas kepartaian. Selain itu, mereka cenderung berorientasi kekuasaan dan fragmatisme, lemahnya manajemen konflik, tidak memiliki figur kharismatik sebagai integrator semua golongan dalam pengendalian polarisasi dan fragmentasi kepartaian, dan potensi solidaritas yang dimiliki kalangan elit Islam lebih berorientasi untuk menonjolkan kekuasaan figur kelompoknya daripada mendukung potensi yang dimiliki di luar kelompoknya.

Menanggapi konflik internal partai politik saat menjelang dan setelah melakukan kongres atau mukhtamar pada 2005, seperti konflik PKB antara kubu Gus Dur/Muhaimin Iskandar dengan kubu Alwi Shihab/Syaifullah Yusuf atau antara kubu Hamzah Haz dengan kubu Suryadharma Ali di PPP saat menjelang dan setelah Silatnas PPP, seorang informan kunci ${ }^{34}$, mengemukakan sebagai berikut:

"Partai politik diharapkan dapatmenyelesaikan berbagai konflik internal dengan baik karena salahsatu fungsi partai politik adalah mengelola konflik. Konflik intemal partai politik itu jangan sampai menimbulkan kejenuhan masyarakat terhadap partai politik, yang menyebabkan timbulnya "politk pasca partai

\footnotetext{
${ }^{34}$ la seorang akademisi dan Ahli Peneliti Utama dan Kepala Pusat Penelitian Politik, Lembaga IImu Pengetahuan (LIPI), Jakarta, dalam HU Kompas, 11 April 2005, hlm. 7.
}

politik" (postpolitical party politics), yaitu masyarakat beralih pada instrumen lain seperti militer.

Itu situasi yang memprihatinkan karena orang di partai bukan berbicara bagaimana memperiuangkan ideologi dan kepentingan rakyat, melainkan memperjuangkan kepentingan pribadi.

Konflik internal ini patut disayangkan, karena di mana pun di dunia ini untuk membangun demokrasi soko gurunya adalah partai politik. Sementara di Indonesia dalam kurun waktu hampir tujuh tahun, sejak tahun 1998, tampak jelas bahwa kepercayaan, harapan, dan dukungan rakyat terhadap partai politik semakin memudar. Indikatornya adalah meningkatnya jumlah golongan putih dalam Pemilu 1999 dan 2004. Kalau ini terus menerus terjadi, dimana kepercayaan rakyat menurun dan kinerja partai semakin menurun dan lebih banyak gontok-gontokan mengenai posisi ketimbang perjuangan, yang kita takutkan, orang akan mencapai ke arah politik pasca-partai. Ini seharusnya belum terjadi di Indonesia".

Karena tidak diarahkan terhadap manfaat positif, konflik politik mengakibatkan kekecewaan di kalangan masyarakat. Seorang informan ${ }^{35}$ mengemukakan sebagai berikut:

"... Begitulah, ketiga partai besar itu (PDIP, $P K B$, dan PAN, pen.) telah memperihatkan wajahnya kepada masyarakat dengan jujur, bahwa mereka suka berkelahi dengan kawan apalagi lawan. Dan, bahwa mereka adalah kelompok yang asyik dengan kepentingan mereka sendiri. Fungsi partai sebagai saluran yang harus dipelihara untuk lalulintas aspirasi rakyat amat sering dilupakan. ... Selebihnya banyak kader yang kecewa bahkan frustasi sehingga tidak ingin lagi aktif di partai. ... Bahwa selama ini para pemimpin negeri ini

\footnotetext{
${ }^{35}$ la seorang kolumnis, dalam HU Republika, 11 April 2005, hlm. 12.
} 
kebanyakan belum punya kepribadian negarawan. Dan kebanyakan mereka diproduksi oleh partai-partai politik."

Data lapangan tersebut menunjukkan bahwa konflik tidak berdampak positif bagi perbaikan partai politik. Jangankan berfungsi untuk menyalurkan aspirasi dan berorientasi terhadap kesejahteraan rakyat, para elitnya pun masih "disibukkan" dengan penyelesaian konflik internal mereka. Dengan demikian, konflik dalam kasus yang diteliti belum dikelola dengan baik, bahkan cenderung direspons negatif olehmasyarakat.

Ada beberapa dampak konflik yang teridentifikasi dalam penelitian ini, di antaranya memperlemah terhadap kedaulatan dan wibawa partai, direspon negatif oleh masyarakat, tidak berpengaruh terhadap progresivitas perubahan sosial (malah cenderung regres), superioritas dan solidaritas kelompok semakin melemah dan terfragmentasi, mengabaikan kepentingan rakyat, dan berpengaruh cukup besar terhadap instabilitas kepengurusan partai politik didaerah.

Meskipun semangat agama dan ideologi Islam mempunyai potensi yang sangat besar pendorong integrasi, namun integrasi yang secara mendasar belum tercermin di dalam integrasi partai-partai Islam. Dari dua kali Pemilu (1999 dan 2004) partaipartai Islam sulit melakukan rasionalisasi atau unifikasi kepartaian. Hal tersebutmenunjukkan sangat lemahnya solidaritas di antara mereka. Walaupun ada integrasi, hanya bersifat politis dan fragmatis, sesaat dan tidak dalam kerangka penataan kelembagaan, dan tidak berorientasi kerakyatan. Artinya, integrasi dan solidaritas di antara mereka baru berfungsi pada saat ada peluang untuk meraih kekuasaan, setelah kekuasaan mereka capai, maka integrasi pun pudar.

Secara konseptual, Khaldun berpendapat bahwa perubahan akan mundur (regres) setelah semangat agama dan solidaritas sosial melemah, berorientasi kekuasaan, berkonflik, dan berfoya-foya (materialistik-fragmatik). Dikaitkan dengan gejala integrasi sosial partai-partai Islam yang secara umum beronientasi pada kekuasaan dan bersifat tentatif serta masih sulit dilakukan rasionalisasi (integrasi) kepartaian, menunjukkan bahwa "solidantas objektif" (solidarity objective) yang didasarkan pada toleransi hubungan primordial-emosional atau sentimen ideologi yang homogen dalam suatu keyakinan tertentu (ukhuwah Islamiyah) untuk memperkokoh hubungan kelompok keagamaan, lebih lemah daripada "solidaritas subjektif' (subjective solidarity) yang didasarkan pada toleransi umum terhadap kelompok eksternal yang terikat oleh kepentingan kekuasaan sesaat (tentatif).

\section{Unsur-unsur Eksternal Penyebab Konflik}

Konflik internal partai politk Islam yang disebabkan oleh pengaruh eksternal tidak cukup kuat mempengaruhi konflik internal. Hal tersebut berbeda dengan era Orde Baru dimana intervensi negara terhadap politik yang menyebabkan konflik internal saat itu cukup kuat. Seorang informan kunci ${ }^{36}$ mengemukakan kepadapeneliti:

"Setelah Orde Baru jatuh, rasanya tidak ada faktor eksternal yang secara nyata meminggirkan partai politik Islam. Faktor internal rasanya yang paling menonjol yang membuat mereka berkonflik; mereka euporia dalam merespons pembentukan partai dan lebih berorientasi kekuasaan daripada mendidik masyarakat melalui proses politik. Kalaupun ada faktor eksternal yang mengakibatkan konflik internal, ya itu tadi hanya bertujuan untuk mengakses berbagai kepentingan, seperti fasilitas, dana, dan

\footnotetext{
${ }^{36}$ Informan ini adalah seorang wartawan dari sebuah media massa.
} 
jaringan, termasuk fasilitas pesantren bagi para kiai yang terlibat di dalamnya."

Sejalan dengan gerakan reformasi, pasca-keruntuhan rezim Orde Baru kekuatan intervensi tersebut sudah melemah. Namun melemahnya intervensi ekstemal (negara) terhadap politk, tidak secara otomatis meredakan konflik internal. Pasca-Orde Baru konflik internal malah cenderung semakin kuat dan terbuka. Hal tersebut pun ditandai oleh fragmentasi kepartaian yang tidak terkendali.

\section{Unsur-unsur Eksternal Penyebab Integrasi} Unsur eksternal penyebab integrasi dilatarbelakangi oleh kepentingan politik dan kekuasaan daripada bertujuan membangun konsensus baru untuk perbaikan kolektivitas partai Islam. Untuk tujuan politik dan kekuasaan, seperti membangun koalisi dengan eksternal partai-partai Islam, dapat menimbulkan kontrovensi di internal partai. Seorang informan ${ }^{37}$ mengemukakan sebagai berikut:

“... Dalam (internal) PKS, masalah ini (koalisi PKS dengan Partai Demokrat) sedang diperdebatkan. Sebab, ada orang (pengurus) yang sama sekali tidak senang terhadap kinerja pemerintahan Presiden SBY (yang didukung PKS) dan mereka merasa orangorang yang terkena getahnya. ... Dari ketiga partai itu (PPP, PAN, dan PKS), yang paling mungkin keluar (mencabut koalisi dengan Partai Demokrat dan mencabut menterinya dari pemerintahan SBY) dan paling punya prinsip adalah PKS, yang lainnya (PPP dan $P A N)$ saya kira akan menjadi oportunistik. ...".

Fenomena tersebut pun relatif berpengaruh terhadapperubahan politik aliran. Pada era Orde Lama, politik aliran; khususnya

\footnotetext{
${ }^{37}$ la seorang guru besar, pengamat dan peneliti politik di Indonesia, berasal dari Amerika Serikat, dikemukakan dalam acara "Mimbar Indonesia, TVRI Nasional, 30 Januari 2006.
}

Islam, cukup mencolok dan relatif tidak bisa membangun koalisi (integrasi) politik dengan partai yang berasas nasionalis-demokratis. Namun, pada pasca-Orde Baru, hal tersebut cenderung banyak dilakukan partai-partai Islam. Di tingkat pusat, misalnya, telah terjadi crossing party coalition "lintas ideologis", seperti antara Poros Tengah (gabungan partai-partai Islam di DPR) dengan PDIP, PPP dengan PDIP, PKB dengan PDIP, PBB dengan Partai Demokrat, dan PKS dengan Partai Demokrat. Demikian pula di tingkat daerah dalam proses Pilkada Kabupaten/ Kota, misalnya, telah terjadi pula koalisi "lintas ideologis" kepartaian. Bahkan, di tingkat daerah, gejala tersebut cenderung berbeda dan lebih beragam dengan di tingkat pusat. Fenomena tersebut cenderung semakin memperkuatnya orientasi kekuasaan daripada memperjuangkan idealisme kepartaian (Islam) dan cenderung semakin mempersulit konsolidasi kepartian.

Berkaitan dengan intergrasi partai-partai non-lslam, seorang informan kunci ${ }^{38}$ mengemukakan:

“... Di era sekarang, untuk melakukan integrasi, mereka mensiasati jalan tengah kesatuan di kalangan partaipartai Islam sebenarnya bias. Meskipun tuntutan syari'at dan tuntutan politik bisa terintegrated, namun 'wajah' politisi Islam telah terjadi degradasi karakteristik kepeminpinan elit Islam. ... Saya pikir, di masa-masa lalu itu elit Islam bersahabat dan mereka siling membesarkan dan mendukung. Pada saat sekarang, jangankan di tingkat elit, di lapisan bawah pun mungkin mereka saling caci-maki. ... Seandainya imam pada kelompok tertentu mampu

\footnotetext{
38 Informan ini adalah seorang aktivis LSM (Lembaga Swadaya Masyarakat) dan pengusaha, juga sering mengunjungi beberapa pesantren besar di Indonesia.
} 
memberikan suatu paradigma kebersamaan, mungkin bisa terintegrasi. Sayang sekali pada saat sekarang elit Islam belum mampu berpikir integral, masih berpikir sektoral. ...Partai Islam di kita lebih baik bekerja sama dengan partai non-Islam atau partai nasionalis bahkan mungkin partai orientalis, selagi menguntungkan bagi kelompoknya bahkan individunya, daripada bekerja sama dengan partai Islam lainnya yang suatu saat akan menjadi front gerakannya. Paradigma seperti ini muncul pada elit politik Islam sekarang. Dulu pada era Pemilu 1999 ada aturan stambus accord, beberapa partai Islam melakukan merger dengan partai nonIslam daripada dengan partai Islam. Ini suatu bukti bahwa mereka mendasarkan gerakannya pada kepenti-ngan politik semata. ...Mereka belum menemukan konsep integrated untuk menyatukan Muhamadiyah, NU, Persis, dan sebagainya. Apalagi menghasilkan satu figur keimamahan yang dapat dijadikan 'poros' bagi semua golongan. ..."
Integrasi politik dalam bentuk koalisi kepartaian tersebut, baik di pusat maupun di daerah, banyak dibangun partai-partai politik Islam meskipun dengan partai di luar Islam bahkan dengan partai non-Islam, seperti yang teridentifikasi dalam koalisi politik dalam Pilkada. Selain itu, integrasi politik yang sifatnya relatif permanen, tidak dibangun oleh rasa kesadaran untuk memperbaiki lembaga kepartaian, tetapi hanya terkondisikan oleh aturan perundang-undangan yang ada, seperti partai-partai Islam yang terkena aturan electoral treshold menjelang Pemilu 2004 menggabungkan dirinya ke dalam PPNUI. Hal tersebut memperkuat berkembangnya gejala bahwa "solidaritas subjektif" (subjective solidarity) yang didasarkan pada toleransi umum terhadap kelompok eksternal, lebih kuat daripada "solidaritas objektif" (objectivesolidarity) yang didasarkan pada toleransi hubungan primordial-emosional atau sentimen ideologi sebagaimana tergambarkan dalam ilustrasi berikut: 


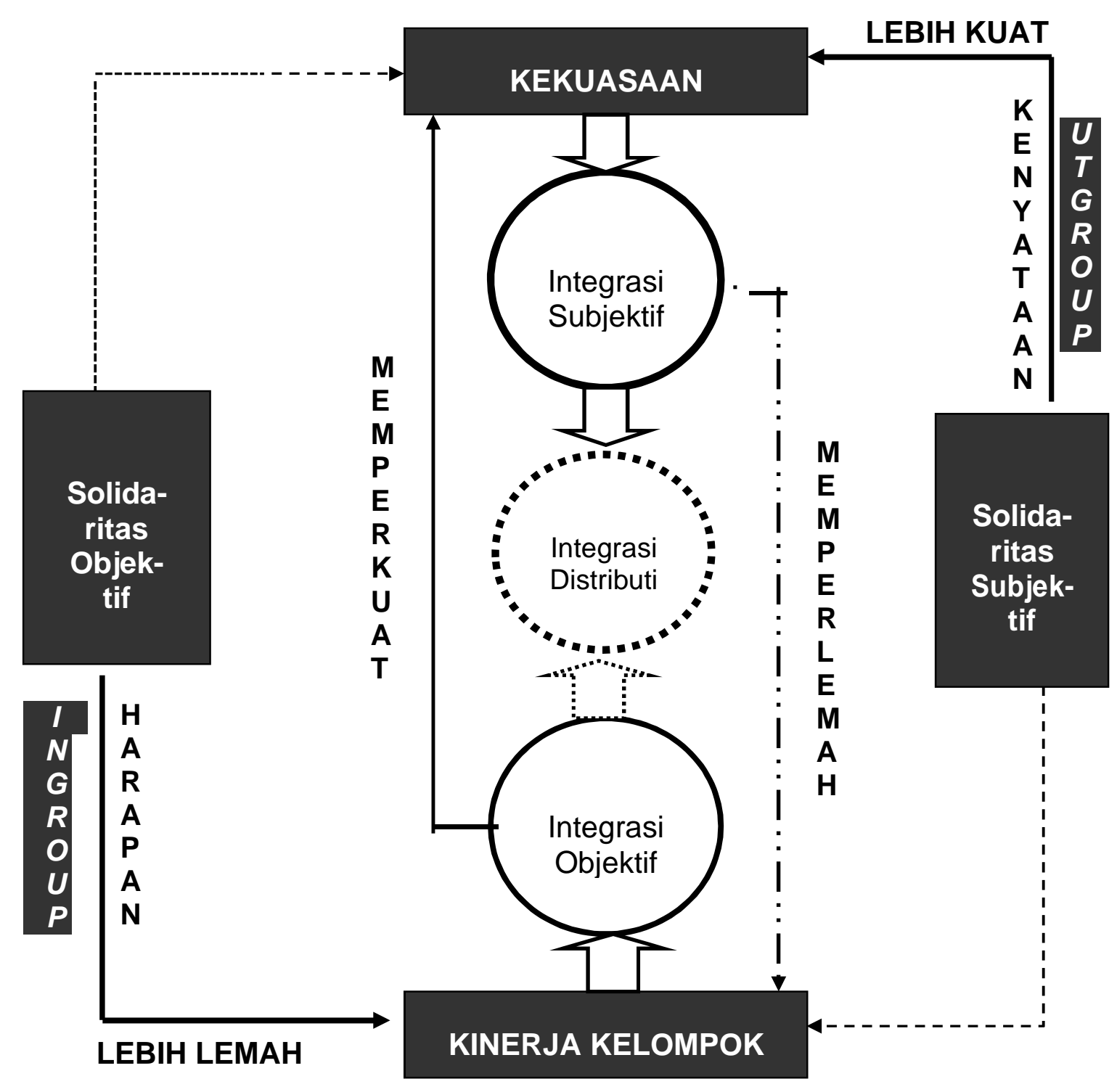

Gambar 2

Relasi Kekuasaan Partai-partai Islam

Gambar tersebut menjelaskan bahwa berdasarkan hasil pengamatan dan analisis penelitian, "solidaritas subjektif" lebih kuat daripada "solidaritas objektif' dalam membangun pola hubungan kekuasaan. Sebagai harapan, memperjuangkan idealitas nilai-nilai keislaman melalui kekuasaan, idealnya memprioritaskan relasi kekuasaan melalui "in group" (kelompok dalam). Dengan cara demikian, kinerja kelompok akan meningkat sehingga terbangun "integrasi objektif dan hal tersebut lebih berpotensi untuk memperkuat kekuasaan kelompok. Setelah fase ini berhasil, baru "in group" 
Gunawan Undang, Husni Thamrin; Konflik dan Integrasi Islam Politik

melakukan hubungan kekuasaan dengan "out group" melalui "integrasi subjektif' sehingga dengan cara demikian kelompok partai Islam memiliki "daya tawar" yang tinggi dalam perebutan kekuasaan. Mamun kenyataan-nya relasi integrasi partai-partai politik Islam cenderung lebih kuat berhubungan dengan "out group" (kelompok luar) daripada dengan "in group" (kelompok dalam). Hal tersebut mengakibatkan terjadinya "integrasi subjektif" yang bertujuan untuk memperoleh "distribusi" (integrasi distributif) kekuasaan sehingga memperlemahterhadap kinerja kelompok "in group" (kelompok dalam).

\section{Resolusi Konflik}

Resolusi konflik berupaya menangani sebab-sebab dan akibat-akibat dari konflik yang terjadi; konflik perlu dikelola dan dikendalikan sehingga berdampak positif terhadap individu atau komunitas yang sedang berkonflik. Secara teoritik, ada dua pendekatan dalam penanganannya, yakni model litigasi (melalui pengadilan) dan nonlitigasi melalui ADR (Alternatif Dispute Resolution) yang menekankan terhadap penyelesaian konflik melalui negosiasi, mediasi, konsiliasi, dan arbitrasi.

Dari pengamatan penulis, penyelesaian konflik politik partai-partai Islam cenderung lebih banyak menggunakan metode nonlitigasi daripada litigasi, baik konflik internal maupun konflik eksternal. Konflik internal yang melanda PPP yang mengakibatkan fragmentasi ke dalam PBR atau konflik pascaSilatnas PPP pada pertengahan Februari 2005; misalnya, yang semula akan diselesaikan melalui jalur litigasi, tetapi pada akhimya mereka selesaikan melalui cara nonlitigasi. Demikian pula konflik internal yang melanda PBR kubu Zainuddin M. Z. dengan kubu Djafar Badjeber/Zaenal Maarif/Bulian Royan pasca-Munas atau Mukhtamar II
(2005), mereka selesaikan dengan cara yang sama, non-litigasi melalui proses negosiasi.

Sedangkan konflik internal yang melanda PKB antara kubu GusDur/Muhaimin Iskandar dengan kubu Alwi Shihab/Syaifullah Yusuf mereka selesaikan melalui proses litigasi di PN Jakarta Selatan yang kemudian disusul oleh putusan kasasi Mahkamah Agung. Namun demikian, sampai dengan bulan Februari 2006, putusan kasasi Mahkamah Agung pun tidak dapat menyelesaikan masalah internal mereka sehingga masih terbentuk kepengurusan "kembar". Meskipun di lingkungan PKB (dan $\mathrm{NU}$ ) banyak sejumlah kiai sepuh kharismatik, tetapi peranan mereka cenderung kurang fungsional dalam melakukan mediasi konflik internal melalui resolusi konflik non-litigasi. Fenomena tersebut menunjukkan bahwa sedang berjalan suatu proses perubahan desakralisasi tokoh kharismatik di lingkungan PKB (danNU).

Dari empat model resolusi konflik melalui pendekatan non-litigasi, pihak yang berkonflik cenderung hanya menggunakan caranegosiasi (kesepakatan melalui proses interaksi langsung antar-pihak yang berkonflik). Sedangkan cara mediasi (kesepakatan yang melibatkan pihak ketiga sebagai mediator atau penengah yang bersifat aktif), konsiliasi (kesepakatan yang melibatkan pihak ketiga sebagai konsiliator atau penengah yang bersifat pasif), dan arbitrasi (kesepakatan yang melibatkan pihak ketiga sebagai arbritor atau penengah yang netral, ditunjuk dan disepakati pihak bertikai yang memiliki wewenang untuk memutuskan dan keputusannya mengikat kedua belah pihak yang bertikai), cenderung tidak ditemukan dalam proses resolusi konflik internal atau konflik antar-partai Islam, sekalipun di lingkungan PKB (dan NU) yang memiliki sejumlah kiai kharismatik yang berpotensi sebagai mediator. 
Model resolusi konflik partai-partai Islam pada umumnya cenderung menggunakan negosiasi, terkecuali PKB. Meskipun PKB memiliki sejumlah kiai khos NU yang berpotensi menjadi mediator, namun mereka menempuh jalur litigasi. Fenomena tersebut menunjukkan bahwa kalangan alim ulama NU yang terlibat ke dalam proses politik PKB belum optimal sebagai mediator konflik internal mereka. Hal tersebut berbeda dengan yang mereka lakukan ketika terjadi konflik antara kubu Gus Dur dengan kubu Hasyim Muzadi pasca-Mukhtamar NU ke-31, November 2004, di mana Gus Dur sempat merencanakan membuat NU tandingan, peranan kiai sangat fungsional. Bahkan, mediasi pun pernah dilakukan para kiai khos NU untuk membela Gus Dur menjelang dijatuhkan dari kursi presiden dalam Sidang Istimewa MPR, 23 Juli 2001. Dengan demikian, fenomena tersebut menunjukkan bahwa kiai kharismatik relatif lemah sebagai mediator dalam proses politik mengatasi konflik internal PKB. Hal tersebut berbeda dengan upaya partai-partai Islam lainnya, walaupun mereka tidakmemiliki kiai kharismatik; baik formal maupun nonformal yang terstrukturkan ke dalam organisasi kepartaian, mereka cenderung mampu menempuh cara-cara non-litgasi melalui negosiasi.

Dari deskripsi di atas, terdapat gambaran umum bahwa resolusi konflik partai-partai Islam pada umumnya menggunakan pendekatan non-litigasi (terkecuali PKB), dan dari empat model pendekatan penyelesaian konflik, partai-partai Islam cenderung lebih banyak menggunakan cara-cara negosiasi.

Model resolusi konflik yang ditawarkan Khaldun lebih menekankan terhadap pendekatan non-litigasi atau hukum akal daripada pendekatan litigasi atau syari'at. Menurutnya, untuk menghindari konflik, cukuplah setiap orang mengetahui bahwa kezaliman diharamkan atasnya berdasarkan hukum akal. Konflik dapat diatasi, baik dengan peranan pemimpin atau usaha masyarakat menjauhkan diri dari pertikaian dan saling berlaku zalim. Hal tersebut dapat dicapai melalui konsensus atau ijma. Dengan demikian, secara konseptual, model pendekatan ADR (Alternatif Dispute Resolution), yang lebih menekankan terhadap penyelesaian konflik melalui negosiasi, mediasi, konsiliasi, dan arbitrasi, lebih memberikan dukungan terhadap teori Khaldun, daripada melalui pendekatan litigasi. Dalam konteks ini, posisi kiai yang memiliki peran yang sangat strategis dan sentral sebagai imam (pemimpin) masyarakat, menjadi sangat penting sebagai penengah penyelesaian konflik untuk melakukan negosiasi, mediasi, konsiliasi, dan arbitrasi.

Konflik-konflik politik partai politik Islam yang pada umumnya dilakukan berdasarkan hukum akal melalui konsensus atau ijma, belum sepenuhnya menghasilkan konsensus baru yang sifatnya mendasar, termasuk untuk memperbaiki kinerja dan rasionalisasi lembaga-lembaga kepartaian yang masih terfragmentasi, tetapi cenderung menekankan terhadap konsensus untuk meraih kemenangan politik dan kekuasaan. Meskipun kemenangan politik dan kekuasaan merupakan salah satu tujuan berpolitik, namun hal tersebut bukan satu-satunya tujuan partai politik. Selain fungsi partai politik sebagai pengeloka konflik dan meraih kekuasaan, ada fungsi lainnya yang lebih substantif, seperti fungsi intermediasi antara pemerintah dan konstituennya dalam mensejahterakan masyarakat dan fungsi pendidikan politik masyarakat. Dengan demikian, resolusi konflik politik mengehendaki tidak hanya diselesaikan berdasarkan tawar-menawar politik dan kekuasaan, tetapi lebih berorientasi membangun konsensus baru untuk memperbaiki partai politik secarakolektivitas, 
Gunawan Undang, Husni Thamrin; Konflik dan Integrasi Islam Politik

dapat meningkatkan kinerja kelompok, dan tujuan kolektivitas partai politik yang berorientasi kemasyarakatan.

\section{Resolusi Konflik Litigasi}

Resolusi konflik politik melalui pendekatan litigasi di internal partai politik Islam pasca-Orde Baru, di antaranya berkembang di kalangan PKB. Konflik yang melibatkan PKB kubu Gus Dur/Muhaimin Iskandar dan PKB kubu Alwi Shihab/Saefullah Yusuf tersebut berakhir di Pengadilan Negeri JakartaSelatan. Pengadilan Negeri Jakarta Selatan memenangkan kubu Gus Dur/ Muhaimin Iskandar, sedangkan di tingkat kasasi Mahkamah Agung, dimenangkan PKB kubu Alwi Shihab/SaefullahYusuf.

Fenomena tersebut menunjukkan bahwa kiai belum berfungsi optimal dalam menyelesaikan konflik-konflik politik internal mereka sehingga berkembang ke proses litigasi. Padahal menurut Horikoshi (1987), kiai menduduki posisi sentral dalam masyarakat; Geertz (1981), kiai adalah tokoh yang mempunyai posisi strategis dan sentral dalam masyarakat; dan Turmudi (2004), kiai menduduki posisi yang sangat terhormat dalam masyarakat.

Secara sosiologis, fenomena konflik di internal PKB yang diselesaikan melalui pendekatan litigasi tersebut menunjukkan gejala melunturnya budaya "samina wa atho'na"39yang berkembang di lingkungan Nahdliyin, khususnya di lingkungan PKB. Gejala melunturnya budaya tersebut pun pernah ditunjukkan oleh "pembangkangan" Matori Abdul Djalil (Ketua Umum PKB pertama yang kemudian dipecat dari jabatannya oleh Gus Dur sebagai Ketua Dewan Syuro PKB) terhadap Gus Dur.Dalam SI MPR, saat itu Matori cenderung mendukung terhadap pengangkatan Megawati sebagai presiden daripada loyal

\footnotetext{
${ }^{39}$ Secara harfiah artinya "kami dengar dan kami taat";
}

kepada Gus Dur yang di-impechment MPR dari kursi kepresidenan. Demikian pula dalam Mukhtamar NU ke-31, November 2004, Ketua Umum NU terpilih Hasyim Muzadi berkonflik dengan Gus Dur sehingga Gus Dur saat itu akan membuat $\mathrm{NU}$ tandingan. Hal tersebut menggambarkan bahwa budaya taklid kalangan warga NU kepada para kiai atau tokoh kharismatik, sedang mengalami proses desakralisasi. Hal tersebut relevan dengan temuan Turmudi (2004) bahwa dalam bidang politik dan pendidikan pesantren, peranan kiai sedang mengalami proses profanisasi kharisma secara gradual, yakni berkurangnya pengaruh kiai dalam masyarakat.

Dalam konteks tersebut, untuk menghindari penyelesaian konflik politik partaipartai Islam melalui pendekatan litigasi, konsep Khaldun tentang perlunya tokoh kharismatik yang memiliki kekuatan wibawa, peranan kiai menjadi sangat penting sebagai mediator konflik dengan pola pendekatan nonlitigasi. Namun apabila netralitas kiai sudah mengalami perubahan karena keterlibatannya pada politik dan kekuasaan, maka posisi strategis tersebut cenderung akan terus melemah sehingga peranannya secara gradual menjadi disfungsional dalam proses resolusi konflikpolitik

\section{Kesimpulan}

Unsur utama yang mempertajam konflik internal dan memperlemah integrasi partai-partai politik Islam adalah lemahnya solidaritas kelompok (in group solidarity), dan konflik bukan disebabkan oleh dua kepentingan yang berbeda, melainkan satu kepentingan yang sama, yakni perebutan kekuasaan (power struggle) yang dipicu oleh perebutan struktur kekuasaan (power structure) lembaga kepartaian yang terfragmentasi secara parokial. Dalam membangun pola hubungan kekuasaan, solidaritas 
subjektif (subjective solidarity) lebih dominan daripada solidaritas objektif (objective solidarity). Meskipun solidaritas objektif berpotensi memperkokoh kesatuan suatu kelompok sosial, namun karena kepentingan solidaritas distributif (distributive solidarity) pembagian kekuasaan dengan kelompok luar (out group) lebih dominan daripada dengan kelompok dalam (in group), maka konsekuensinya integrasi subjektif (subjective integrations) lebih kuat daripada integrasi objektif (objective integrations). Integrasi objektif yang tidak dilatarbelakangi oleh kesadaran solidaritas kelompok akan menghambat integrasi kelembagaan partai yang terfragmentasi. Fragmentasi berpotensi mendorong konflik dan memperlemah integrasi jika tidak diperkuat oleh ikatan solidaritas objektif sehingga suasana konfliktual akan terus berlangsung dan hal tersebut dapat menghambat progresivitas perubahan. Solidaritas objektif adalah unsur utama yang dapat mengatasi konflik, meningkatkan integrasi, membangun konsensus baru, meningkatkan kinerja kelompok, dan sebagai prasyarat dalam membangun pola hubungan saling ketergantungan (interdependent) dengan kelompok luar. Inilah kontribusi konseptual penelitian ini yang dikembangkan dari teori Khaldun di mana indikator-indikator solidaritas dalam paradigma baru tersebut lebih dispesifikasikan ke dalam unit-unit konsep yang lebih terukur. Sedangkan kontribusi konseptual tentang konflik pada penelitian ini, berbeda dengan perspektif Marxis yang berpandangan konflik adalah mekanime yang mendorong progresivitas perubahan, sementara konflik partai-partai Islam; sebagaimana dikonseptualisasikan
Khlaldun, justru menghambat progresivitas perubahan, karena muatan konflik partai-partai Islam lebih bersifat politis daripada ideologis.

Model resolusi konflik non-litigasi melalui ijtihad kolektif yang dimediatori para kiai dalam penyelesaian konflik partai-partai Islam dapat dikembangkan, sejauh fungsi informal kiai sebagai ummatan wasathon tidak mengalami pergeseran. Namun, otoritas kiai akan mengalami keterbatasan dalam penyelesaian konflik-konflik politik, jika fungsi informal kiai bergeser dari perantara budaya (cultural brokers) menjadi perantara politik (political brokers), karena posisi kiai akan terjepit dalam struktur lembaga kepartaian Islam yang fragmentasi. Secara gradual, kharisma kiai pun akan mengalami desakralisasi dalam proses kepemimpinan politik sehingga menuntut kiai melakukan reorientasi khittah-nya. Pergeseran fungsi informal kiai pada era pasca-Orde Baru tersebut merupakan paradigma baru penelitian ini yang dikembangkan dari konsep Khaldun tentang "fragmentasi kekuasaan dan kharisma figur", dan konsep Geertz, Horikoshi, dan Turmudi yang secara terbatas mengkonseptualisasikan fungsi kiai pada aspek budaya dan politik pada era Orde Lama dan Orde Baru.

Dipandang dari aspek kulturalsosiologis, arah gerakan partai politik Islam pasca-Orde Baru berubah dari pendekatan politik substantif-kontekstual(rasional) ke pendekatan politik simbolik-tekstual (skriptual). Sedangkan secara struktural-politis, berubah dari polarisasi politik aliran(ideologis) ke fragmentasi politik parokial (fragmatis). Secara konseptual, gejala perubahan tersebut menyimpang dari konsep gerakan pembaruan pemikiran Islam politik substantif (kultural)yang digagas kalangan intelektual Islam (CakNur, 
dkk.) pada era Orde Baru, karena konsep tersebut belum sepenuhnya bisa diadaptasi kalangan politisi Islam yang masih bersandar pada simbolisasi agama. Meskipun tetap berpotensi, namun sejumlah indikator menunjukkan trend simbolisasi agama tidak efektif dalam meraih kepercayaan masyarakat pemilih sebagaimana tercermin dari rendahnya raihan suara partai-partai Islam pada Pemilu 1999 dan 2004. Oleh karenanya, gerakan partai politik Islam ke depan cenderung mengarah pada model politik profetik, yakni politik yang membawa misi risalah kenabian yang menyimbiosiskan secara harmonis hubungan antara agama dan konstitusi negara Indonesia (legalkonstitusional) dalam wadah partai yang tidak secara ketat terikat pada partai tertentu; apalagi yang hanya bersimbol keislaman, meskipun secara substantivistik hakikat gerakannya tetap memberikan kemaslahatan bagi tegaknya nilai-nilai ajaran Islam. Sebab dengan cara demikian, diharapkan Islam sebagai rahmatan li'alamiin dapat diwujudkan termasuk dalam kemajemukan agama, suku, dan bahasa di Negara Kesatuan Republik Indonesia yang berdasarkan Pancasila yang merupakan bentuk final dan ideal bagi rakyat Indonesia

\section{DAFTAR PUSTAKA}

\section{Buku}

Abdul Azis Dahlan. 1999. Dalam Ensiklopedi Hukum Islam, Jilid 5. Jakarta: PT Ichtiar Baru van Hoeve.

Abdul Munir Mulkhan. 1989. Perubahan Perilaku Politik dan Polarisasi Ummat Islam 1965-1987: Dalam Persspektif Sosiologis. Cet. I. Rajawali Pers, Jakarta.

Abudin Nata. 1999. Metodologi Studi Islam. Raja Grafindo Persada, Jakarta.
Ade Armando. 1993. "Citra Kaum Pembaru Islam dalam Propaganda Media Dakwah", dalam Jurnal IImu dan Kebudayaan “Umul Qur'an”, Nomor 3, Volume IV, 1993, halaman 66-76. Jakarta: Lembaga Studi Agama dan Filsafat (LSAF) dan ICMI.

Affan Gafar. 1993. "Islam dan Politk dalam Era Orde Baru: Mencari Bentuk Artikulasi yang Tepat", dalam Jumal Ilmu dan Kebudayaan "Umul Qur'an", Nomor 2, Volume IV, 1993, halaman 18-25. Jakarta: Lembaga Studi Agama dan Filsafat (LSAF) dan ICMI.

A. Hafizh Dasuki (Pemimpin Redaksi). 1994. Ensiklopedi Islam, Jilid 1-5 dan Suplemen 1-2. Ichtiar Baru van Hove, Jakarta.

-_---1 1999. Ensiklopedi Hukum Islam, Jilid 1-5. Ichtiar Baru van Hove, Jakarta. Ahmad Syafii Maarif. 1993. "Politik dalam Perspektif Islam", dalam Jurnal IImu dan Kebudayaan "Umul Qur'an", Nomor 2, Volume IV, 1993, halaman 3. Jakarta: Lembaga Studi Agama dan Filsafat (LSAF) dan ICMI. 1996. Islam dan Politik: Teori Belah Bambu Masa Demokrasi Terpimpin (1959-1965). Cet. I. Gema Insani Press, Jakarta.

Ahmad Sukardja. 2002. Dalam Ensiklopedi Tematis Islam. Jakarta: PT Ichtiar Baru van Hoeve.

Al Chaidar. 1999. Pemilu 1999:

Pertarungan Ideologis Partai-partai Islam versus Partai-partai Sekuler. Darul Falah, Jakarta.

Al Ghazali. 1975. Ihya Ulumuddin; Bimbingan untuk Mencapai Tingkat Mukmin (terj. Moh. Abdai Rathoni). CV Diponegoro, Bandung. Alfian. 1981. Pemikiran dan Perubahan Politik Indonesia. Gramedia, Jakarta. 
Ali, Maulana Muhammad. 1977. Islamologi (Dinul Islam), (terj. R. Kaelan dan H. M. Bachrun). Darul Kutubil Islamiyah dan PT Ichtiar Baru - Van Hoeve, Jakarta.

Aminudin. 1999. Kekuatan Islam dan Pergulatan Kekuasaan di Indonesia: Sebelum dan Sesudah Runtuhnya Rezim Soeharto. Pustaka Pelajar, Yogyakarta.

Andrain, Charles F. 1992. Kehidupan Politik dan Perubahan Sosial, (terj. Luqman Hakim). Cet. I. Tiara Wacana, Yogya.

Anton M. Moeliono (Penyunting Penyelia). 1996. Kamus Besar Bahasa Indonesia. Balai Pustaka, Jakarta.

A. Rahman Zainuddin. 1992. Kekuasaan dan Negara: Pemikiran Politik Ibnu Khaldun. PT Gramedia Pustaka Utama, Jakarta.

----- 2002. "Pemikiran dan Peradaban" dalam Ensiklopedi Tematis Dunia Islam, Buku 4. Jakarta: PT Ichtiar Baru van Hove.

Astrid S. Susanto. 1983. Pengantar Sosiologi dan Perubahan Sosial. Binacipta, Bandung.

Azyumardi Azra. 1993. "Islam dan Negara: Eksperimen dalam Masa Modern, Tinjauan Sosio-Historis", dalam Jurnal IImu dan Kebudayaan “Umul Qur'an”, Nomor 2, Volume IV, 1993, halaman 10-16. Jakarta: Lembaga Studi Agama dan Filsafat (LSAF) dan ICMI. 1999. Renaisans Islam Asia

Tenggara: Sejarah Wacana dan Kekuasaan. PT Remaja Rosdakarya, Bandung.

Bahtiar Effendy. 1998. Islam dan Negara: Transformasi Pemikiran dan Praktik Politik Islam di Indonesia. Paramadina, Jakarta.

Balandir, Georges. 1996. Antropologi Politik, (terj. Y. Budisantoso). PT Raja Grafindo Persada, Jakarta.
Ba-Yunus, llyas dan Farid Ahmad. 1996. Sosiologi Islam \& Masyarakat Kontemporer, (terj. Hamid Basyaib). Mizan, Bandung.

Bellah, Robert N. 1992. Religi Tokugawa, Akar-akar Budaya Jepang,(terj. Wardah Hafidz \& Wiladi Budiharga). Gramedia Pustaka Utama, Jakarta.

Benda, Harry J. 1980. Bulan Sabit dan Matahari Terbit: Islam Indonesia pada Masa Pendudukan Jepang, (terj. Daniel Dhakidae). Pustaka Jaya, Jakarta.

Boland, B. J. 1985. Pergumulan Islam di Indonesia,(terj. Saafroedin Bahar). Cet. I. Grafiti Pers, Jakarta.

Bottomore, Tom. 1992. Sosiologi Politik, (terj. Sahat Simamora). Cet. II. Rineka Cipta, Jakarta.

Bruinessen, Martin van. 1994. NU: Tradisi, Relasi-relasi Kuasa, Pencarian Wacana Baru, (terj. Farid Wajidi). Yogyakarta: Lkis bekerjasama dengan Pustaka Pelajar.

Campbell, Tom. 1999. Tujuh Teori Sosial: Sketsa, Penilaian, Perbandingan,(terj. F. Budi Hardiman). Cet. IV. Kanisius, Yogyakarta.

Chadwick, Bruce A. et. al. 1988. Social Science Research Methods. Prentice Hall, Ind. Englewood Cliffs, New Jersey.

Claessen, H. J. M. 1987. Antropologi Politik: Suatu Orietasi. Erlangga, Jakarta.

Dahrendorf, Ralf.1959. Class and Class Conflict in Industrial Society. tanfordUniversity Press, California.

Deddy Mulyana. 2001. Metodologi Penelitian Kualitatif: Paradigma Baru IImu Komunikasi dan IImu Sosial Lainnya. PT Remaja Rosdakarya, Bandung. 
Gunawan Undang, Husni Thamrin; Konflik dan Integrasi Islam Politik

Deliar Noer. 1996. Gerakan Modern Islam di Indonesia 1900-1942. Cet. VIII. LP3ES, Jakarta.

---2000. Partai Islam di Pentas Nasional: Kisah dan Analisis Perkembangan Politik Indonesia 1945-1965. Mizan, Bandung.

DepagRI. 1996. Al-Quran Al-Qarim dan Terjemahnya. CV Toha Putra, Semarang.

Djuhendi Tadjudin. 2000. Manajemen Kolaborasi. Bogor: Latin.

Duverger, Maurice. 1998. Sosiologi Politik, (terj. Daniel Dhakidae). Cet. VI. PT Raja Grafindo Persada, Jakarta.

Eep Saefulloh Fatah. 2000. Zaman Kesempatan: Agenda-agenda Besar Demokratisasi Pasca-Orde Baru. Cet. I. Mizan, Bandung.

Endang Turmudi. 2004. Perselingkuhan Kiai dan Kekuasaan. LKIS, Yogyakarta.

Esposito, John L. (Ed. Kepala). 2001. Ensiklopedi Oxpord: Dunia Islam Modern, Jilid $1-6$ (terj. Eva Y. N., dkk.). Mizan, Bandung.

Feith, Herbert. 1999. Pemilihan Umum 1955 di Indonesia, (terj. Nugroho Katjasungkana, dkk.). Kepustakaan Populer Gramedia, Jakarta.

Geertz, Clifford. 1982. Abangan, Santri, Priyayi dalam Masyarakat Jawa, (terj. Aswab Mahasin). Pustaka Jaya, Jakarta.

1994. Politik Kebudayaan, (terj. Francisco Budi Hardiman). Cet. II. Kanisius, Yogyakarta.

---- 1999. Kebudayaan dan Agama, (terj. Francisco Budi Hardiman). Cet. V. Kanisius, Yogyakarta.

Giddens, Anthony. 1999. The Third Way: Jalan Ketiga Pembaruan Demokrasi Sosial, (terj. Ketut Arya Mahardika). Gramedia Pustaka Utama, Jakarta.
Ginung Pratidina, "Manajemen Konflik dalam Meningkatkan Efektivitas Organisasi", dalam majalah 'Wawasan Tridharma", Kopertis Wilayah IV, No. 10 Tahun XV, Mei 2003, halaman 35.

Gunawan Undang. 2001. "Perubahan Sosial dalam Gerakan Partai Politik Islam Pasca-Orde Baru: Kekuatan Intervensi Eksternal dan Konflik Internal, Studi Kasus di Jawa Barat, Tesis. Program Pascasarjana Unpad, Bandung.

Haedar Nashir. 1999. Fragmatisme Politik Kaum Elit. Pustaka Pelajar, Yogyakarta.

Hamid Basyaib dan Hamid Abidin (Ed.). 1999. Mengapa Partai Islam Kalah?: Perjalanan Politik Islam dari PraPemilu 1999 sampai Pemilihan Presiden. Alvabet, Jakarta.

Hamid, Tijani Abd. Qadir. 2001. Pemikiran Politik dalam Al-Quran, (terj. Abdul Hayyie al-Kattani). Gema Insani Press, Jakarta.

Hartono Mardjono. 1997. Politik Indonesia (1996-2003). Gema Insani Press, Jakarta.

Harun Nasution. 1975. Pembaharuan dalam Islam, Sejarah Pemikiran dan Gerakan. Bulan Bintang, Jakarta. 1985. Islam Ditinjau dari Berbagai Aspeknya, Jilid I. Jakarta: UI Press. 1986. Islam Ditinjau dari Berbagai Aspeknya, Jilid II. Jakarta: UI Press. Herman Soewardi. 2001. Mempersiapkan Kelahiran Sains Tauhidullah. Bakti Mandiri, Bandung. 2001. Roda Berputar, Dunia Bergulir: Kognisi Baru Tentang Timbul Tenggelamnya Sivilisasi . Bakti Mandiri, Bandung. 
---- 2002. Kognisi-Karsa-Nalar (Dasardasar untuk Kebangkitan Islam dalam Millenium 3). Bakti Mandiri, Bandung. 2003. Mellenium 3: Kebangkitan Islam yang Sebenarnya. Bandung Circle, Bandung.

----2004a. Sosiologi, Membangkitkan Karsa Umat: Tumpuan Utama Bagi Pembangunan. Bakti Mandiri, Bandung.

---2004b. Sosiologi Agama:Perpaduan Empirik \& Normatif. Bakti Mandiri, Bandung.

---2004c. Filsafat IImu: Induk Sains Empirikal. Bakti Mandiri, Bandung. Horikoshi, Hiroko. 1987. Kyai dan Perubahan Sosial,(terj. Umar Basalim dan Andi Muarly Sunrawa). P3M, Jakarta.

Horton, Paul B. dan Chester L. Hunt. 1996. Sosiologi, Jilid 1 dan 2, (terj. Aminuddin Ram). Ed. VI. Jakarta: Erlangga.

Husni Thamrin. 2001. "Agama, Kultur, dan Kekuasaan: Fenomena Islam Politik di Indonesia", dalam Jurnal IImu Sosial dan IImu Politik "Cakradonya”, Volume 1, Nomor 1, Juni 2001. Banda Aceh: FISIP Universitas Iskandarmuda, halaman 64--75.

Husnul Aqib Suminto. 1996. Politik Islam Hindia Belanda. LP3ES, Jakarta.

Ibrahim Hosen. 1993. "Fiqh Siyasah dalam Tradisi Pemikiran Islam Klasik". Jurnal IImu dan Kebudayaan "Ulumul Quran”, Nomor 2, Volume IV, 1993, halaman 58-66. Jakarta: Lembaga Studi Agama dan Filsafat (LSAF) dan ICMI.

Idrus Affandi. 1996. "Kepeloporan Organisasi Kemasyarakatan Pemuda dalam Pendidikan Politik (Suatu Analisis tentang Pengembangan Kepemimpinan dalam Perspektif
Budaya Politik Pemuda di Jawa

Barat)", Disertasi. Program

Pascasarjana IKIP Bandung,

Bandung.

Izutsu, Toshihiko. 1994. Konsep

Kepercayaan dalam Teologi Islam:

Analisis Semantik Iman dan Islam,

(terj. Agus Fahri Husein). PT Tiara

Wacana Yogya, Yogyakarta.

Jalaluddin Rakhmat. 1991. Islam Alternatif.

Mizan, Bandung.

1996. Islam Alternatif. Mizan,

Bandung.

1999. Rekayasa Sosial: Reformasi

atau Revolusi? PT Remaja

Rosdakarya, Bandung.

Jonge, Hubb de (Ed.). 1989.Agama, Kebudayaan, dan Ekonomi. Jakarta: Rajawali Pers.

Johnson, Doyle Paul. 1986. Teori Sosiologi Klasik dan Modern, Jilid 1 dan 2,(terj. Robert M. Z. Lawang). PT Gramedia, Jakarta.

Judistira K Garna. 1999. Metoda Penelitian: Pendekatan Kualitatif. Primaco Akademika CV, Bandung.

Juhaya S. Pradja. 2000. Filsafat IImu: Menelusuri Struktur Filsafat IImu dan IImu-ilmu Islam. Program

Pascasarjana IAIN Sunan Gunung Djati, Bandung. 2003. Islam dan Terorisme. Cemers Binghamton University, New York. 2006. 'Islam Post 911, Indonesians' Experience", The Public Lecture on Criminal Policy, International Efforts to Overcome the Threat of Terorism, 27 Januari 2006, Japan: The United Nations Asia and Far East Instaitute for the Prevention of Crime and the Treatment of Offenders (UNAFEI), Japan Criminal Policy Society, and Asia Crime Prevension Foundation (ACPF). 
Gunawan Undang, Husni Thamrin; Konflik dan Integrasi Islam Politik

Kementerian Penerangan Republik Indonesia. 1951. Kepartaian di Indonesia, Pepora (8). Kementerian Penerangan Republik Indonesia, Jakarta.

Khaldun, Ibn. 1962. Ibnu Chaldun: Tentang Masjarakat dan Negara (terj. Osman Raliby). Bulan Bintang, Jakarta. 2000. Muqaddimah, (terj. Ahmadie Thoha). Pustaka Firdaus, Jakarta. Kusnaka Adimihardja. 2000. "Investigasi Potensi Konflik Sosial di Berbagai Daerah di Indonesia", dalam Laporan Akhir "Social Conflict Resolution", Volume V, Laporan Seminar, Oktober 2000. Bandung: Forum Rektor Yayasan Pengembangan Sumber Daya Manusia, halaman $1-3$. .

----2000. "Catatan dari Lapangan: Potensi Konflik di Berbagai Daerah di Indonesia", dalam Majalah "Transformasi", Volume 1, Nomor 2, Juli-September 2000. Bandung: Yayasan Pengembangan Sumber Daya Manusia - Forum Rektor, halaman 59-63 dan 76-78. dan Ibnu Hadjar. 2000. "Konflik dan Resolusi Konflik: Kasus di Provinsi Sumatera Utara". Laporan Penelitian. Bandung: Forum Rektor.

----- 2001. "Amok Massa di Tasikmalaya: Kotra Santri yang Ramah dan Santun di Jawa Barat" dalam Jurnal IImu Sosial dan Politik "Cakradonya", Volume 1, Nomor 1, Juni 2001. Banda Aceh: FISIP Universitas Iskandarmuda, halaman $1-8$. 2003. "Budaya Tradisional dan Lokal di Tengah Multikultur Nasional dan Arus Global". Majalah "Transformasi", Volume 3, Nomor 1, Januari-Maret 2003. Bandung: Yayasan Pengembangan Sumber Daya
Manusia - Forum Rektor, halaman 28-33.

--_-dan Purnama Salura. 2004. Arsitektur dalam Bingkai Kebudayaan. Bandung: Foris Publishing.

Laode Ida. 1996. Anatomi Konflik: NU, Elit Islam dan Negara. Pustaka Sinar Harapan, Jakarta.

Lauer, Robert H. 1993. Perspektif tentang Perubahan Sosial,(terj. Alimandan S. U.). Cet. II. Rineka Cipta, Jakarta.

Lexy J. Moleong. 1997. Metodologi Penelitian Kualitatif. Cet. 8. Remaja Rosdakarya, Bandung.

Liddle, R. William. 1993. "Skriptualisme Media Dakwah: Satu Bentuk Pemikiran dan Aksi Politik Islam Masa Orde Baru", dalam Jumal IImu dan Kebudayaan "Umul Qur'an", Nomor 3, Volume IV, 1993, halaman 53-65. Jakarta: Lembaga Studi Agama dan Filsafat (LSAF) dan ICMI.

Lloyd, Christopher (ed.). 1986. Teori Sosial dan Praktek Politik,(terj. Nazaruddin Sjamsuddin, dkk.). Cet. I. CV Rajawali, Jakarta.

Loekman Soetrisno. 2003. Konflik Sosial: Studi Kasus Indonesia. Yogyakarta: Tajidu Press.

M. Dhiauddin Rais. 2001. Teori Politk Islam, (terj. Abdul Hayyie al-Kattani, dkk.). Gema Insani Press, Jakarta.

M. Din Syamsuddin. 1993. "Usaha Pencarian Konsep Negara dalam Sejarah Pemikiran Politik Islam", dalam Jurnal IImu dan Kebudayaan "Umul Quran", Nomor 2, Volume IV, 1993, halaman 4--9. Jakarta: Lembaga Studi Agama dan Filsafat (LSAF) dan ICMI.M. Rusli Karim. 1999. Negara dan Peminggiran Islam Politik. Cet. I. TiaraWacana Yogya, Yogyakarta. 
Ma'arif Jamuin. 1999. Manual Advokasi: Resolusi Konflik Antar-Eknik dan Agama. Solo: Ciscor.

Masri Singarimbun dan Sofian Effendi (ed.). 1989. Metode Penelitian Survai. LP3ES, Jakarta.

Moh. Nazir. 1988. Metode Penelitian. Ghalia Indonesia, Jakarta.

Moten, Abdul Rashid. 2001. Ilmu Politik Islam, (terj.Munir A. Mu'in \& Widyawati). Pustaka, Bandung. Muhammad Ahmad. 1998. Tauhid IImu Kalam. Pustaka Setia, Bandung.

Munawir Sjadzali. 1993. Islam dan Tata Negara: Ajaran, Sejarah, dan Pemikiran. Jakarta: UI-Press.

Noeng Muhajir. 1998. Metodologi Penelitian Kualitatif. Edisi III, Cet. 8. Rake Sarasin, Yogyakarta.

Nurcholish Madjid. 1993. "Beberapa Renungan tentang Kehidupan Keagamaan untuk Generasi Mendatang", Jurnal IImu dan Kebudayaan "Ulumul Quran”, Nomor 1, Volume IV, 1993, halaman 4-25. Jakarta: Lembaga Studi Agama dan Filsafat (LSAF) dan ICMI.

----- 1994. Islam, Kerakyatan, dan Keindonesiaan. Mizan, Bandung.

---- 1998. Islam, Kemodernan, dan Keindonesiaan. Mizan, Bandung.

Osman Raliby. 1962. Ibnu Chaldun tentang Masjarakat dan Negara. Bulan Bintang, Jakarta.

Usman Pelly. 1993. "Pengukuran Intensitas Potensi Konflik dalam Masyarakat Majemuk", dalam Majalah "Analisis CSIS", Tahun XXII, Nomor 3, MeiJuni 1993, halaman 187-193.

Rachmadi Usman. 2003. Pilihan Penyelesaian Sengketa di Luar Pengadilan. Bandung: Citra Aditya Bakti.
Ritzer, George. 1992. Sosiologi Ilmu Pengetahuan Berparadigma Ganda, (terj. Alimandan). PT Raja Grafindo Persada, Jakarta.

Ritzer, George dan Goodman, Douglas J. 2005. Teori Sosiologi Modem, (terj.Alimandan), Prenada Media, Jakarta.

Rush, Michael dan Philip Althoff. 1997. Pengantar Sosiologi Politik,(terj. Kartini Kartono). Cet. VI. PT Raja Grafindo Persada, Jakarta.

Rusidi. 1992. Dasar-dasar Penelitian dalam Rangka Pengembangan IImu. Program Pascasarjana Unpad, Bandung. 1999. Seri Kuliah 1999 UNX-693b: Metode Penelitian. Program Pascasarjana Unpad, Bandung.

Soerjono Soekanto. 2001. Sosiologi: Suatu Pengantar. Jakarta: Rajawali Pers. 2002. Mengenal Tujuh Tokoh Sosiologi. Jakarta: Raja Grafindo Persada.

S. Nasution. 1992. Metode Penelitian Naturalistik Kualitatif. Tarsito, Bandung.

Soni A. Nulhakim. 2005. Manajemen Kolaborasi Resolusi Konflik dalam Perkelahian Antar-Warga di Daerah Perkotaan (Studi Kasus: Palmeriam dab Berlan di Jakarta Timur). Bandung: Program Pascasarjana Unpad.

Spiegel, Steven L. dan Kenneth N. Waltz (Ed.). 1971. Conflict in World Politics. Winthrop Publishers, Inc., Cambridge, Massachusetts.

Sunatra. 1997. "Integrasi dan Konflik: Kedudukan Politik Jawara dan Ulama dalam Budaya Politik Lokal (Studi Kasus Kepemimpinan Informal Perdesaan di Banten Selatan); Integration and Conflict: Political Position of Jawara and Ulama in Local 
Gunawan Undang, Husni Thamrin; Konflik dan Integrasi Islam Politik

Political Cultural (a Case Study of the Informal Leadership Patern in the Village Area of South Banten)", Disertasi. Program Pascasarjana Unpad, Bandung.

Suwarsono dan Alvin Y. SO. 1991. Perubahan Sosial dan Pembangunan di Indonesia: Teori-teori Modemisasi, Dependensi, dan Modern. Cet. I. LP3ES, Jakarta.

Suyud Margono. 2004. ADR dan Arbitrasi: Proses Pelembagaan dan Aspek Hukum. Bogor: Ghalia Indonesia. Syaifullah. 1997. Gerakan Politik Muhammadiyah dalam Masyumi.PT Pustaka Utama Grafiti, Jakarta. Syamsuddin Haris. 1993. "Politik Islam PPP dan Pemilu 1992: Perjuangan Mencari atau Mempertahankan Identitas", dalam Majalah "Analisis CSIS", Tahun XXII, Nomor 3, MeiJuni 1993, halaman 194-204.

Taimiyah, Ibnu. 1995. Siyasah Syariyah: Etika Politik Islam, (terj. Rofi' Munawwar). Risalah Gusti, Surabaya. Tanter, Richard dan Keneth Young. 1993. Politik Kelas Menengah Indonesia, (terj. Nur Iman Subono). PT Pustaka LP3ES, Jakarta.

Taufik Abdullah (Ketua Dewan Editor). 2002. Ensiklopedi Tematis Dunia Islam. PT Ichtiar Baru Van Hoeve, Jakarta.

Turner, Byan S. 1983. Sebuah Studi Kritik tentang Weber dan Islam, (terj. M. Asy'ari, dkk.). Proyek Pembinaan Perguruan Tinggi Agama/IAIN di Jakarta, Direktorat Pembinaan Perguruan Tinggi Agama Islam, Jakarta.

Varma, S. P. 1999. Teori Politik Modem, (terj. Yohanes Kristianto SL, dkk.). Raja Grafindo Persada, Jakarta.
Voll, John Obert. 1997. Politik Islam: Kelangsungan dan Perubahan di Dunia Modem,(terj. Ajat Sudrajat). Titian llahi Press, Yogyakarta.

Wertheim, W. F. 1999. Masyarakat Indonesia dalam Transisi: Studi Perubahan Sosial,(terj. Misbah Zulfa Elizabet). Cet. I. PT Tiara Wacana, Yogyakarta.

Zhafir M. A. Pontoh (Ed.). 2000. "Laporan Akhir "Social Conflict Resolution", Volume V, Laporan Seminar, Oktober 2000. Bandung: Forum Rektor Yayasan Pengembangan Sumber Daya Manusia. 2000. "Laporan Akhir "Social Conflict Resolution", Volume VII, Tabulasi Peta Konflik, Oktober 2000. Bandung: Forum Rektor - Yayasan Pengembangan Sumber Daya Manusia. 